\title{
A PROLEGOMENON TO \\ GROWTH MANAGEMENT AND EXCLUSIONARY ZONING ISSUES*
}

\author{
JAMES F. BLUMSTEIN $\dagger$
}

\section{INTRODUCTION}

This symposium considers the broad topic of urban growth and the control or management of that growth by various techniques of government intervention. The purpose of this article is to provide an overview of legal developments in the growth management area. It is not designed to discuss or catalogue each and every case. What it is intended to do, however, is to show that the federal courts have consistently eschewed active intervention in this area when, at the same time, selected state courts have made headlines by intervening agressively in the land use regulation process.

State government's authority to regulate comprehensively the use of land is derived from the police power. ${ }^{1}$ States have the inherent power to legislate to promote the public health, safety, morals, and general welfare. ${ }^{2}$ In contrast, local governments only possess authority expressly or impliedly

\footnotetext{
* Research for this article was supported, in part, by the Vanderbilt Institute for Public Policy Studies. The author is grateful to Professor Erwin C. Hargrove, Director of the Institute, for his personal and the Institute's institutional support; to Professors Jeffrey A. Schoenblum and JohnMark Stensvaag of the Vanderbilt Law School for their comments on a draft of this article; and to P. Michael Richardson and Carol Miller, Class of 1980 and 1981, respectively, at the Vanderbilt Law School, for their research assistance.

† Professor of Law, Vanderbilt Law School; Senior Research Associate, Vanderbilt Institute for Public Policy Studies.

1. Village of Euclid v. Ambler Realty Co., 272 U.S. 365 (1926). See generally D. HAGMAN, Urban Planning and Land Development Control Law 76-77 (1971).

2. The states are "the residual repository of all governmental power in the federal system." D. Mandelker \& D. Netsch, State and Local Government in a Federal System 27 (1977). Typically this power is attributed to the tenth amendment: "The powers not delegated to the United States by the Constitution, nor prohibited by it to the States, are reserved to the States respectively, or to the people." U.S. Const. amend. X. Thus, state legislatures can enact legislation without specific statutory or constitutional authorization in the exercise of their inherent police powers. Federal and local governments, on the other hand, have limited power. A source of authority must be identified for legislation enacted by these levels of government. In the absence of such a source of power, legislation is unwarranted.

In many states courts have developed and incorporated into state constitutions a concept of public purpose as a limitation on the state police power. Under this principle state legislatures may not act for private, as opposed to public, purposes. See 6 E. McQuillin, Municipal CorpoRATIONS $\$ 24.09$ (3d ed. 1969).
} 
granted by either state constitutional or legislative provisions. ${ }^{3}$ Typically, states have delegated their police power authority in the land use control field to local units of government by enactment of enabling legislation; ${ }^{4}$ this allows local governmental bodies to carry out land use planning and regulatory functions. ${ }^{5}$

The general validity of a comprehensive governmental regulation of land use and the permissibility of a local unit of government's exercising this authority were established in the seminal Euclid v. Amber Realty Co. ${ }^{6}$ That decision involved a facial challenge to a suburban Cleveland village's comprehensive zoning plan. In sustaining the constitutionality of the zoning ordinance, the Court emphasized the neighborhood effects that emanate from any individual's use of his own land. ${ }^{7}$ Although these external effects did not reach so far as to be considered a nuisance under traditional court-derived principles, they legitimately served as a basis to warrant government regulatory intervention.

Euclid, therefore, established two principles that have been pivotal in the evolution of American land use law: (1) government in general may regulate comprehensively land use patterns, even if a use prohibited by a zoning ordinance would not be so noxious on its own to warrant a finding of nuisance; and (2) state governments may delegate their regulatory authority in the land use field to local units of government.

While establishing these broad propositions, the Court carefully announced principles of limitation which have served as important sources of litigation challenging restrictive local government regulatory actions. First, while rejecting the facial challenge in Euclid, the Court ruled that landowners have the right to attack the constitutional validity of a zoning ordinance as applied to their particular parcel of land. Alleged individualized injustice could be

3. See D. Mandelker \& D. Netsch, supra note 2, at 148-51.

4. State governments often adopt comprehensive enabling legislation that authorizes action by local governments. Most states have used the Standard State Zoning Enabling Act (SSZEA) as a general model. U.S. Dep't of Commerce, SSZEA (1926) reprinted in 3A Rathkopf, The LAw of Zoning and Planning 765 (4th ed. 1979). The SSZEA authorized local governments to divide their territory into districts, with regulations governing height, area, and bulk, in addition to use. The SSZEA, and state statutes modeled after it, assumed that the purpose of local zoning laws was to prohibit undesirable development, not to encourage desirable development.

The ALI Model Land Development Code (Official Draft No. 1, 1975) is designed to provide a more modern framework for planning law than the SSZEA, a product of the 1920's. Like the SSZEA, it also focuses on physical development of land, not social and economic objectives.

5. Local legislatures may not exceed the bounds of the power delegated to them. The socalled "Dillon's Rule" confines these powers to those expressly granted to a local entity, those necessary to or implied by powers expressly granted, and those essential to declared objectives of the local entity. The rule is in essence one of strict construction against an expansive reading of state enabling legislation. D. MANdelKer \& D. NetSCH, supra note 2, at 150.

6. 272 U.S. 365 (1926).

7. Id. at 391-95. 
raised on a case by case basis even though the overall zoning power existed and was exercised reasonably. ${ }^{8}$ In the subsequent Nectow $v$. City of Cambridge ${ }^{9}$ decision, the Court sustained the claim of an individual landholder who asserted that a zoning ordinance was invalid as applied to his parcel, thereby giving explicit recognition to the pattern of land use challenges that would be entertained in the post-Euclid era. Indeed, the Nectow case has influenced the course of landowner challenges, establishing the existence of a federal constitutional issue in the application of a local zoning ordinance. ${ }^{10}$

The second principle of limitation articulated in dictum in Euclid concerned the authority of local governments to control land use. Although local decision making units might well legislate in their own interests at the expense of broader regional welfare, the Court suggested that there might be constitu-

8. Id. at 395.

9. Nectow v. City of Cambridge, 277 U.S. 183 (1928). The relief awarded in Nectow was an injunction against enforcement of the invalid land use restriction. This has been labeled the "Nectow fallacy" by Professor Robert Ellickson, who suggests that a damages remedy would be more appropriate than injunctive relief when a court invalidates a land use restriction against private property. See Ellickson, Suburban Growth Controls: An Economic and Legal Analysis, 86 Y ALE L.J. 385, 490 (1977). See generally notes 607-21 and accompanying text infra.

10. Since the Nectow decision in 1928 the Supreme Court has not been active in adjudicating individual landowner grievances against allegedly oppressive land use regulations. Nectow arose during the activist economic substantive due process era when governmental restrictions on private rights were routinely invalidated as arbitrary and unreasonable. More recent Supreme Court decisions suggest a more permissive attitude in regard to regulation of private property, as one would expect given the erosion of the economic substantive due process doctrine in the last forty years. In the 1978 Penn Central decision the Court indicated the wide scope of governmental regulatory power in the land use area. Penn Cent. Transp. Co. v. New York City, 438 U.S. 104 (1978). See also Village of Belle Terre v. Boraas, 416 U.S. 1 (1974); Goldblatt v. Hempstead, 369 U.S. 590 (1962).

Surprisingly, the constitutional doctrine of "taking" has evolved in state courts in a way more consistent with the decisions of the economic substantive due process era than with the more recent decisions that reflect the demise of economic substantive due process as a viable federal constitutional doctrine. This is partially explained by the Supreme Court's reluctance to involve itself with these cases. State courts continue to rely upon the Euclid-Nectow guidelines.

Much of the confusion in the area, however, may be traced to the earlier decision in Pennsylvania Coal Co. v. Mahon, 260 U.S. 393 (1922). In Pennsylvania Coal, a coal company had sold surface rights to a property while retaining rights to subsurface minerals. The Pennsylvania legislature enacted legislation that barred owners of subsurface mineral rights from exploiting those resources if surface properties would be significantly impaired. The Supreme Court invalidated the act.

Instead of holding the statute unconstitutional under a traditional economic due process analysis, the Court introduced the concept of "taking." Justice Holmes suggested that when regulation went too far, the governmental regulatory activity constituted a "taking" of private property that must be compensated. The difference between taking and regulation was one of degree, not kind. Thus, Pennsylvania Coal, which suggests that a different form of analysis is appropriate in "taking" situations than is used in the economic substantive due process area, has helped spawn the apparent divergence between the zoning cases, in which judicial review is still seriously exercised, and the other economic regulatory areas, in which judicial review is essentially a rubber stamp of legislative judgments. See Section V, D., infra.

For criticism of the Pennsylvania Coal approach, see F. Bosselman, D. Callies \& J. Banta, The TAKING ISSUE 124-95 (1973). 
tional limits on the authority of local units of government to control land use when parochial interests were clearly outweighed by overriding regional needs. ${ }^{11}$ Presumably, there could be a point beyond which a local political unit, unaccountable to any political constituency other than its own resident voters, could not act on issues of regional import. That is, the Court's dictum implied that, although promotion of local welfare was generally an appropriate frame of reference for local zoning measures, there were undefined constitutional boundaries to the ability of local governments to favor their own welfare at the expense of the broader common good.

The fundamental principles established in Euclid have influenced the format of subsequent land use litigation (the vast bulk of it in state courts). The Nectow-style challenges have focused on the rationales for and reasonableness of specific restrictions on the use of land. Over time, state courts developed a comprehensive body of case law based on Euclid and Nectow, but it was not until Goldblatt v. Town of Hempstead in 1962 that the Supreme Court again entered the arena. ${ }^{12}$ Its intervention in Goldblatt and since ${ }^{13}$ has resulted in an increasingly permissive approach toward governmental regulation of land use. With respect to the Euclid dictum concerning a local unit's possible regional duties, the Supreme Court has declined numerous invitations to develop dictum into doctrine. ${ }^{14}$ The Court's reticence in developing the regionalism dictum and its narrowing of the Nectow opening have meant that federal court challenges to local land use regulations have met with scant success. Some state courts, however, have asserted themselves actively in the land use area, building on the Nectow ${ }^{15}$ and regionalism ${ }^{16}$ openings. As a consequence, they have inserted themselves aggressively in the policy making proccess that involves balancing collective with individual interests and regional with local concern.

This article will discuss some of the techniques of intervention adopted by the state courts, built upon the Euclid dicta and the Nectow decision. It will show how the rationales developed by the state courts have been resisted by the federal courts, which have not only declined to look seriously at regional considerations, but have also undercut much of the basis for federal intervention even in Nectow situations. Finally, the article will examine two statutory

\footnotetext{
11. 272 U.S. at $389-90$.

12. 369 U.S. 590 (1962).

13. Penn Cent. Transp. Co. v. New York City, 438 U.S. 104 (1978)

14. See Village of Belle Terre v. Boraas, 416 U.S. 1 (1974). See also James v. Valtierra, 402 U.S. 137 (1971).

15. See National Land and Inv. Co. v. Kohn, 419 Pa. 504, 215 A.2d 597 (1965).

16. See Associated Home Builders v. City of Livermore, 18 Cal. 3d 582, 557 P.2d 473, 135 Cal. Rptr. 41 (1976); Southern Burlington County NAACP v. Township of Mount Laurel, 67 N.J. 151, 336 A.2d 713 (1975), appeal dismissed, 423 U.S. 808 (1975); Berenson v. Town of New Castle, 38 N.Y. 2d 102, 341 N.E. 2d 236, 378 N.Y.S. 2d 672 (1975); Township of Willistown v. Chesterdale Farms, Inc., 462 Pa. 445, 341 A.2d 466 (1975).
} 
alternatives that seem to bear some promise for litigants who challenge land use restrictions.

\section{The Problem}

At the outset, it is helpful to trace briefly the evolving perceptions of the problem of suburban growth controls. Planning and regulation of land use through zoning were easy to promote as techniques for coping with widely recognized external effects of land usage. The judge-made law of nuisance was seen by planning proponents as something of a blunderbuss, requiring an egregious interference by one landowner with the interests of another before a judicial remedy could be invoked. It was not difficult to make the case that governmental intervention was appropriate at some stage prior to a finding of nuisance, provided the intervention was aimed at protecting individual property owners or members of the community generally from a harm imposed by a contextual misuse of land. ${ }^{17}$

But as is so often the case when governmental intervention is sought, the justification for intervention in the abstract may command consensus while specific application of governmental policy elicits conflict. The idea of establishing zones where specified uses would be restricted seemed reasonable enough as a means for protecting certain roses from designated weeds. ${ }^{18}$ Thus, exclusion of factories from residential areas-even where nuisance law would not warrant injunctive relief ${ }^{19}$ — seemed a justifiable form of governmental regulation. But since the theory of zoning was inherently exclusionary, the inevitable issues would and did arise: What are roses and which ones are worthy of protection and appropriate to protect? Is it appropriate to protect a rose, not from weeds, but from honeysuckle? Furthermore, at what cost is it acceptable to maintain large rose gardens when planters of other worthy flowers are clamoring for more space to cultivate their favorite seedling ? $^{20}$

17. Some commentators, however, have expressed skepticism about the value of zoning as an effective form of land use regulation. They suggest that conflicts among neighboring landowners might be better resolved by systems less centralized than those of master planning and zoning. These commentators prefer to rely on private, non-regulatory alternatives, such as covenants. See Ellickson, Alternatives to Zoning: Covenants, Nuisance Rules, and Fines as Land Use Controls, $40 \mathrm{U}$. Chi. L. Rev. 681 (1973); Siegan, Non-Zoning in Houston, 13 J. LaW \& Econ. 71 (1970).

18. The form of zoning upheld in Euclid was hierarchical. The most restrictive zone permitted only single-family residences. Since each lower use category added permissible uses while also allowing the higher use classification in that zone, single-family residences were permitted in all zones. This form of hierarchical or cumulative zoning has been labeled Euclidian.

19. See, e.g., Boomer v. Atlantic Cement Co., 26 N.Y. 2d 219, 222, 257 N.E. 2d 870, 871, 309 N.Y.S. 2d 312,314 (1970).

20. For consideration of these issues in the context of zoning ordinances that restrict mobile homes, compare the New Jersey decision in Vickers v. Township Comm. of Gloucester Tnshp., 37 
These exclusionary issues were never far from the surface in zoning controversies even in the Euclid case. In sustaining a comprehensive zoning ordinance, the Court acknowledged that some uses "of an innocent character might fall within the proscribed class." 21 Nevertheless, a restrictive regulatory scheme would not be stricken for overinclusiveness because some "reasonable margin to insure effective enforcement" 22 was necessary in light of the difficulty in drawing distinctions between compatible and less compatible uses.

But for the Euclid Court, it was the exclusion of apartments and all business and commercial uses from residential districts that posed the most troublesome aspect of the case. ${ }^{23}$ Looking at the issue from the perspective of the landowner, the Court was concerned that the exclusion of apartments from residential areas unjustifiably foreclosed a profitable and productive use. To Justice Sutherland and a property-rights oriented Court, what apparently was persuasive for permitting the exclusion was the argument that apartments can be "parasites" 24 in single-family residential neighborhoods. That is, they "take advantage of the open spaces and attractive surroundings" 25 created by the single-family residences.

Moreover, the coming of one apartment house is followed by others . .
bringing, as their necessary accompaniments, the disturbing noises incident to
increased traffic and business . . until, finally, the residential character of the
neighborhood and its desirability as a place of detached residences are utterly
destroyed. Under these circumstances, apartment houses, which in a different
environment would be not only entirely unobjectionable but highly desirable,
come very near to being nuisances. ${ }^{26}$

Consequently, it was the perception of negative external effects from apartment houses that led the Court in Euclid to legitimize exclusion of apartment houses from single-family residential areas. The exclusionary impact indeed was the primary justification for that particular land use restriction. Nevertheless, Justice Sutherland's description of the negative effect was carefully confined to physical impacts-blocking the rays of sun, increasing noise and traffic. ${ }^{27}$

It did not take much imagination for planners and local government officials, however, to perceive and act on the opportunity left open by Euclid. Rationales for restrictive land use controls expanded from the protection against

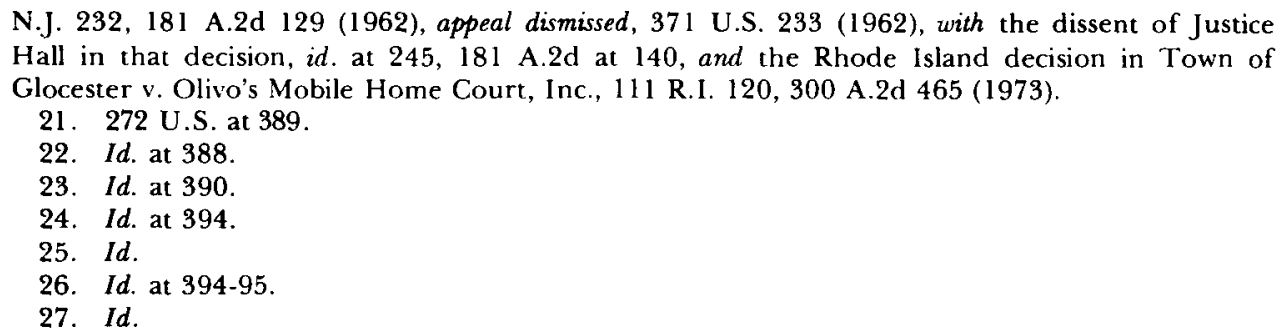


physical side effects to the amorphous concept of "preserving the character" of a community. Use of this broader rationale made distinct what had only been gossamer earlier - that zoning and other regulatory tools in the hands of local government could be used to influence the socioeconomic character of a community. Thus the concept of "exclusionary zoning" was born, a phrase that is something of a misnomer since zoning is necessarily exclusionary, but nevertheless communicative of a sentiment that local governments were wielding land use tools as a means of shaping the socioeconomic (and perhaps racial) composition of their communities. ${ }^{28}$

State courts legitimated the "character of the community" rationale, permitting local units of government considerable discretion in determining what land uses were entitled to protection and the degree of protection to be afforded. A particularly explicit example of judicial solicitude for the suburban community's exclusionary interests was the opinion of Chief Justice Vanderbilt for the New Jersey Supreme Court in the 1952 case of Lionshead Lake, Inc. v. Township of Wayne. ${ }^{29}$ The challenge in Lionshead Lake involved a minimum dwelling size ordinance, which meant that 80 percent of the existing buildings in parts of the township were out of compliance. ${ }^{30}$

The court sustained the ordinance on two separate grounds. First, and less significantly in this context, Chief Justice Vanderbilt credited the township's mental health rationale-that the township could impose reasonable minimum dwelling size requirements because of the adverse psychological effects of overcrowding on the family. ${ }^{31}$ Second, and more consequential for this discussion, the court accepted the view that dwelling size influences the character of the community, and "minimum floor-area standards are necessary to protect the character of the community." 32 The character of the community rationale was separated explicitly from the public health justification by Chief Justice Vanderbilt:
But quite apart from these considerations of public health which cannot be overlooked, minimum floor-area standards are justified on the ground that they promote the general welfare of the community and ... the courts ... take a broad view of what constitutes general welfare. ${ }^{33}$

The implications of the majority opinion in Lionshead Lake were not lost on Justice Oliphant, who dissented "from the philosophy and the result arrived

28. See generally Haar, Zoning for Minimum Standards: The Wayne Township Case, 66 HaRv. L. Rev. 1051 (1953); Sager, Tight Little Islands: Exclusionary Zoning, Equal Protection, and the Indigent, 21 Stan. L. Rev. 767 (1969). For a summary of issues involved in exclusionary zoning, see Bigham \& Bostick, Exclusionary Zoning Practices: An Examination of the Current Controversy, 25 VAND. L. REv. 1111 (1972).

29. 10 N.J. 165, 89 A.2d 693 (1952), appeal dismissed, 344 U.S. 919 (1953).

30. Id. at $168,89 \mathrm{~A} .2 \mathrm{~d}$ at 694 .

31. Id. at $173,89 \mathrm{~A} .2 \mathrm{~d}$ at 697 .

32. Id. at $174,89 \mathrm{~A} .2 \mathrm{~d}$ at 697 .

33. Id. 
at in the majority opinion." ${ }^{4}$ He observed that the township's minimum dwelling size ordinance precluded individuals who could not afford the requisite size house "from ever establishing a residence" ${ }^{35}$ in Wayne Township. ${ }^{36}$

In his classic dissent ten years later in the Vickers $^{37}$ case, in which a ban on mobile homes was upheld, Justice Hall noted that relaxed judicial review of suburban zoning decisions gave "almost boundless freedom to developing municipalities to erect exclusionary walls on their boundaries, according to local whim or selfish desire, and to use the zoning power for aims beyond its legitimate purposes." 38 He was particularly critical of the expanded scope of permissible purposes the courts had accepted as justifications for zoning. Justice Hall proposed that the only permissible purpose to justify zoning should be to promote physical planning objectives, not the vague "character of the community" 39 notions approved in Lionshead Lake and subsequent decisions:

We should not forget some fundamentals. Zoning is land use control by physical planning to bring about physical results for public, not private, welfare. It is not a device to be used to accomplish any and all purportedly desirable social results un related to the statutorily stated purposes . . . . Certainly "general welfare" does not automatically mean whatever the municipality says it does, regardless of who is hurt and how much. And no matter how broadly the concept is viewed, it cannot authorize a municipality to erect a completely isolationist wall on its boundaries. ${ }^{40}$

Over time, the concerns expressed in the Lionshead Lake and Vickers dissents, amplified by numerous commentators, ${ }^{41}$ focused on both the purpose promoted by local land use restrictions and the effect of those limitations. The next Section will consider the approaches developed by state courts in Pennsylvania and New Jersey to the problem of exclusionary zoning-to combat the perceived inequity of restrictive local land use regulations. In Section IV the states of New York and California will be used to illustrate the more permissive attitude that has evolved to restrictive land use policies designed to manage urban growth.

34. Id. at $181,89 \mathrm{~A} .2 \mathrm{~d}$ at 701 .

35. Id.

36. Id. For more extensive analysis of the Lionshead Lake opinion see Haar, supra note 28. See also Southern Burlington County NAACP v. Township of Mount Laurel, 67 N.J. 151, 193, 336 A.2d 713, 735 (1975) (Pashman, J., concurring).

37. Vickers v. Township Comm., 37 N.J. 232, 181 A.2d 129 (1962), appeal dismissed, 371 U.S. 233 (1963).

38. Id. at 252-53, $181 \mathrm{~A} .2 \mathrm{~d}$ at 140 .

39. Id. at $261-63,181 \mathrm{~A} .2 \mathrm{~d}$ at 145 .

40. Id.

41. See Haar, supra note 28; Haar, Wayne Township: Zoning for Whom-In Brief Reply, 67 HARv. L. REv. 986 (1954); Sager, supra note 28. 


\section{Exclusionary Zoning: Pennsylvania and New Jersey}

As a litigation strategy, plaintiffs who sought to challenge local land use regulations could formulate an attack on the basis of either purpose or effect. Under a purpose approach the rationale would be, as Justice Hall had suggested, that the exclusionary goals were impermissible under either the police power or the enabling legislation. ${ }^{42}$ The purpose analysis could have two facets. The state's inherent police power requires that legislation be in furtherance of a public health, safety, morals, or general welfare objective-that is, it must promote a public purpose ${ }^{43}$ One approach would emphasize that preservation of the character of a community, with its implicit or explicit socioeconomic overtones and undercurrents, is an impermissible private rather than public purpose. ${ }^{44}$ The second form of purpose challenge would rely on the language of the state enabling legislation, arguing that specific implementation devices adopted by local governments were not authorized by the pertinent state enabling legislation. ${ }^{45}$

The purpose analysis, from a plaintiff's perspective, raises serious problems of proof. ${ }^{46}$ It requires the production of evidence of intent, not always easy to uncover, and, furthermore, encourages well counseled local governments to inhibit litigation duplicitously by creating a suitably antiseptic public record. ${ }^{47}$ For plaintiffs, therefore, an effect standard has the distinct advantage of being more objectively determinable, thereby increasing the prospects of success in litigation. The problem in seeking an effect standard is to establish a convincing rationale for its adoption.

42. 37 N.J. at 261,181 A.2d at 145 .

43. Legislation may not serve purely private interests. 6 E. MCQUiLLIN, supra note 2.

44. The Kohn court used this reasoning:

There is no doubt that many of the residents of this area are highly desirous of keeping it the way it is, preferring, quite naturally, to look out upon land in its natural state rather than on other homes. These desires, however, do not rise to the level of public welfare. This is purely a matter of private desire which zoning regulations may not be employed to effectuate.

$419 \mathrm{~Pa}$. at $531,215 \mathrm{~A} .2 \mathrm{~d}$ at 611 .

45. This is the approach of Bristow v. City of Woodhaven, 35 Mich. App. 205, 192 N.W. 2d 322 (1971). Compare it and the dissenting opinion in Golden v. Planning Bd. of Ramapo, 30 N.Y. 2d 359, 383, 285 N.E. 2d 291, 305, 334 N.Y.S. 2d 138, 156 (1972) (Breitel, J., dissenting), appeal dismissed, 409 U.S. 1003 (1972), with the Golden majority, 30 N.Y. 2d at 370-71, 285 N.E. 2d at 297, 334 N.Y.S. 2d at 145-46 for an illustration of varying interpretations of enabling legislation language.

46. See generally Brest, Palmer v. Thompson: An Approach to the Problem of Unconstitutional Legislative Motive, 1971 Sup. CT. REv. 95; Ely, Legislative and Administrative Motivation in Constitutional Law, 79 Yale L.J. 1205 (1970).

47. In Village of Arlington Heights v. Metropolitan Hous. Dev. Corp., 429 U.S. 252, 264-68 (1977), the Court listed factors which could lead to a finding of impermissible purpose. That list could be used as a virtual handbook of duplicity to well-counseled local governments who seek to cover their tracks. 
At least two grounds are typically advanced for justifying an effect analysis. The first is primarily an evidentiary rationale, where the occurrence of an event is so likely to have resulted from an improper action that proof of the result is deemed sufficient, at least to make out a prima facie case. In these situations - the tort doctrine of res ipsa loquitur is an example ${ }^{48}$ - the showing of an effect casts the burden of going forward with rebuttal evidence on the party that might have better access to data and thereby be in a better position to present evidence. In this context, the reliance on an effect standard does not alter the basic underlying theory of liability. It is essentially an evidentiary allocation of the burden of adducing evidence, shifting some of the responsibility to a defendant once a prima facie showing of impact has been established by a plaintiff. The defendant, however, has an oportunity to rebut the prima facie case by presenting evidence that refutes the inference of improper purpose. ${ }^{49}$

A second justification for an effect test is more substantive in character. In this context, the showing of an impact is conclusive in finding liability. ${ }^{50} \mathrm{Be}$ fore this form of liability formula makes sense, however, there must be a prior determination that a substantive duty or obligation exists whose breach can be ascertained purely on the basis of a numerical showing. This use of impact evidence changes the fundamental theoretical basis for liability because purpose no longer is relevant even theoretically in determining culpability. An outcome deemed unsatisfactory is sufficient to impose liability under this for-

48. Res ipsa loquitur ("the thing speaks for itself") is a form of circumstantial evidence used in tort cases. One may infer both negligence and causation from the mere occurrence of an event and a defendant's relation to it if: (a) the event would not ordinarily occur in the absence of negligence; (b) evidence eliminates other responsible causes; and (c) the indicated negligence is within the scope of the defendant's duty to the injured party. Restatement (SECOND) of Torts, $\$ 328 D$ (1966). This inference is not irrebuttable. W. Prosser, Handbook of the Law of Torts 233-35 (4th ed. 1971).

49. This seems to be the approach adopted by the federal courts in race discrimination matters. See Village of Arlington Heights v. Metropolitan Hous. Dev. Corp., 429 U.S. 252, 270 n.21 (1977). See also Mt. Healthy City Bd. of Educ. v. Doyle, 429 U.S. 274, 287 (1977).

50. The tort counterpart to this is the doctrine of strict liability. In some circumstances a defendant may be held strictly liable for harm caused by his actions without an indication of wrongdoing on his part or even a departure by him from a reasonable standard of care. W. Prosser, supra note 48 , at 495 . The most widespread application of the concept is in the products liability field. Restatement (Second) of Torts, supra note 48 , at $\$ 402$ A and Commentary. The defendant is held liable because of a social decision on risk allocation and compensation, not because of individualized determinations of culpability. W. Prosser, supra note 48, at 495. For economic critiques of the doctrine, see Epstein, A Theory of Strict Liability, 2 J. Legal Stud. 151 (1973); Posner, Strict Liability: A Comment, 2 J. Legal Stud. 205 (1973).

In some circumstances, defendants may be able to justify their behavior because of an overriding interest. That is, despite the normally impermissible impact of specified conduct, a court may decide that the result must be countenanced in particular circumstances where offsetting values are necessarily implicated. That approach, characteristic of the strict scrutiny form of federal equal protection review, has been applied by the eighth circuit in a Fair Housing context. United States v. City of Black Jack, 508 F.2d 1179 (8th Cir. 1974). See generally notes $649-68$ infra. 
mulation; rebuttal evidence concerning purpose is beside the point.

Given this overview of purpose and effect theories of liability, it remains to consider the cases in which the state courts have developed rationales for striking exclusionary land use regulations. Developments in Pennsylvania will be examined in some depth and compared with parallel doctrines in New Jersey, New York and California.

\section{A. Pennsylvania}

One of the most significant plaintiff's cases is the Pennsylvania Supreme Court's decision in National Land and Investment Co. v. Kohn. ${ }^{51}$ Kohn involved a challenge to the validity of a four-acre minimum lot size legislated by a suburban community. Justice Roberts approached the problem from the perspective of the landowner whose land had been effectively devalued by governmental regulations ${ }^{52}$ and from the perspective of the potential residents to whom a locality had some undefined duty of nonexclusion. ${ }^{53}$ From the court's opinion, holding invalid the large lot provision of Easttown Township, it was clear that the burdensome impact on land values weighed especially heavily in the court's determination. Thus, Justice Roberts warned that zoning "involves governmental restrictions upon a landowner's constitutionally guaranteed right to use his property, unfettered, except in very specific instances, by governmental restrictions." ${ }^{44}$ Justice Roberts said that the complexity of the issues involved should not lead courts to abdicate "their judicial responsibility to protect the constitutional rights of individual citizens." 55

Concerned about governmental restrictions on private property interests, the court proceeded to address the issue of appropriate governmental objectives in land use regulation matters. In clear terms, the court held that suburban communities could not "shirk their responsibilities" to shoulder the "economic burdens which time and natural growth invariably bring." often quoted passage, Justice Roberts noted that the purpose of zoning is to "plan for ... not ... deny the future." ${ }_{57}$ If a reasonable use of land meant the public investment would be necessary to accommodate development, then the court was prepared to impose a duty of accommodation on the locality. Local governments would not be permitted to use large lot zoning as a means of avoiding the fiscal impact of growth on public expenditures nor as a means of protecting the old-time ambience of a suburban community.

In formulating a standard by which to judge suburban land use restric-

\footnotetext{
51. 419 Pa. 504.215 A.2d 597 (1965).

52. Id. at $522,215 \mathrm{~A} .2 \mathrm{~d}$ at 607 .

53. Id. at 532, $215 \mathrm{~A} .2 \mathrm{~d}$ at 612 .

54. Id. at $522,215 \mathrm{~A} .2 \mathrm{~d}$ at 607 .

55. Id.

56. Id. at $528,215 \mathrm{~A} .2 \mathrm{~d}$ at 610 .

57. Id.
} 
tions in Kohn the Pennsylvania Supreme Court used a purpose analysis. Although it was apparent that the court envisioned chaos if localities were permitted to deny to a growing population sites for residential development within the means of "at least a significant segment of the people," 58 and, as a consequence, concluded that the concept of general welfare necessitated a broader focus than the parochial interests of a local unit of government, nevertheless, in articulating its conclusion, the court wrote in terms of purpose or intent:

A zoning ordinance whose primary purpose is to prevent the entrance of newcomers in order to avoid future burdens, economic and otherwise, upon the administration of public services and facitities can not be held valid .... It is clear ... that the general welare is not fostered or promoted by a zoning ordinance designed to be exclusive and exclusionary. ${ }^{59}$

Consequently, in Kohn the court held invalid a large lot zoning ordinance because the purpose was impermissibly parochial and exclusionary. For the Pennsylvania court, the preservation of the character of the community for the benefit of existing landowners was not a public but a private purpose. ${ }^{60}$ While government could not protect the interests of the large estates, it also could not regulate restrictively the lot size of developments in order to keep public expenditures down. The court invoked the as yet undefined notion of regional responsibility to conclude that the four acre minimum lot size requirements impermissibly interfered with the landowner's constitutionally protected property rights. But the court's language seemed limited to the situation where the community intended to restrict development for one of the purposes the court had deemed improper.

It was not long, however, before the Pennsylvania court expanded the language in Kohn to establish an effect standard. This was done without any fanfare, merely by announcing that Kohn established more than it had seemed to: "We decided in National Land [Kohn] that a scheme of zoning that has an exclusionary purpose or result is not acceptable in Pennsylvania."61 Thus, in 1970, the Pennsylvania Supreme Court held invalid a two acre minimum lot size because it was not "a necessary size for the building of a house." 62 While minimum lot sizes were not inherently unreasonable, ${ }^{63}$ a two acre minimum would be considered unreasonable prima facie "[a]bsent some extraordinary justification." ${ }^{64}$

In Kit-Mar Builders, Concord Township sought to justify the two and

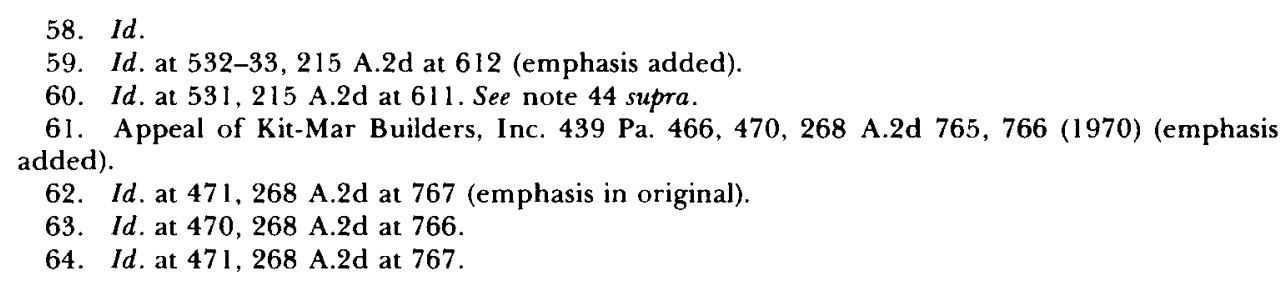


three acre minima primarily on the basis of potential sewerage problems. Relying on Kohn, the court rejected potential sewerage problems as an "excuse" for "exclusionary zoning." 65 Justice Roberts regarded Kohn as having established that because there are "alternative methods for dealing with nearly all the problems that attend a growth in population, including sewage problems, zoning which had an exclusive purpose or effect could not be allowed." 66

The engrafting of the effect language on the purpose analysis of Kohn certainly reflected an expansion of the Kohn formulation by Kit-Mar Builders. There is no question that Justice Roberts in Kit-Mar Builders placed greater emphasis on the duty of localities to accommodate the interests of prospective residents than he had in Kohn. He acknowledged the importance of the interests of prospective newcomers in a footnote: "Although National Land [Kohn], and this problem in general, is postured as involving the constitutional due process rights of the land-owner whose property has been zoned adversely to his best interests, it cannot realistically be detached from the rights of other people desirous of moving into the area in search of a comfortable place to live.' "67 He also carefully reaffirmed the duty of suburban communities to accommodate growth: a community cannot "keep out people, rather than make community improvements." 68 That is, "communities must deal with the problems of population growth .... It is not for any given township to say who may or may not live within its confines, while disregarding the interest of the entire area." 69

Given the stress on a locality's duty to prospective residents to accommodate rather than thwart growth, it is arguable that the effect language of KitMar Builders made proof of purpose immaterial. The court outlined permissible ways by which communities could cope with development efficiently, prominently espousing the flexibility of the planned unit development, ${ }^{70}$ which had been approved by the Pennsylvania Supreme Court in $1968 .^{71}$ What is left unanswered is whether the community that uses planned unit development techniques would be subject to judicial second guessing if it chose a balance of land use patterns not in conformity with maximum balanced residential development. Indeed, if some substantive regional duty underlay the decision in Kit-Mar Builders, the contour of that standard was not identified or articulated but remained submerged. The court, for example, made no state-

65. Id. at $472,268 \mathrm{~A} .2 \mathrm{~d}$ at 767 .

66. Id, at $473,268 \mathrm{~A} .2 \mathrm{~d}$ at 768 .

67. Id. at 474 n.6, 268 A. 2 d at 768 n.6 (citation omitted).

68. Id. at $474,268 \mathrm{~A} .2 \mathrm{~d}$ at 768 .

69. Id. at $474,268 \mathrm{~A} .2 \mathrm{~d}$ at $768-69$.

70. Id. at 475-76, 268 A.2d at 769. For a thorough legal discussion of planned unit development, see Symposium: Planned Unit Development, 14 U. PA. L. Rev. 3 (1965).

71. Village 2 at New Hope, Inc., 429 Pa. 626, 241 A.2d 81 (1968). 
ment about whether the local community has a special duty to accommodate prospective residents from diverse socioeconomic backgrounds.

The vagueness of the regional duty established in Kit-Mar Builders made it difficult to apply an effect test in a substantive way: The proof of what impact, standing alone, would make out a constitutional violation? Rather, it seems probable that the court was adopting the effect standard as an evidentiary device. Once it could be shown that there were less restrictive land use controls consistent with admittedly valid local environmental concerns, the burden of justifying the more restrictive controls fell on the local zoning officials. The court undercut many of the permissible purposes often utilized by local officials to justify restrictive land use regulations, ${ }^{72}$ but the suggestion that planned unit development was a preferred mechanism for accommodating growth implied that certain undefined strategies of balancing economic with housing interests might be acceptable.

This view would indicate that Kit-Mar Builders added an effect component to the Kohn purpose formulation in order to facilitate a plaintiff's satisfying his burden of proof; it shifted the responsibility to the local government to justify its land use control system once a prima facie exclusionary effect were shown. ${ }^{73}$ However, no clearly articulable substantive regional duty was estab-

72. The court eliminated use of sewerage problems, housing, school and recreational facility needs, traffic congestion, and public transportation costs as grounds for restrictive zoning. 439 Pa. at 475, $268 \mathrm{~A} .2 \mathrm{~d}$ at 769 . Aesthetic considerations, such as maintaining rural or historic surroundings, were also rejected. $I d$. at $472 \mathrm{n} .5,268 \mathrm{~A} .2 \mathrm{~d}$ at $767 \mathrm{n} .5$.

73. That Kit-Mar Builders can be read as an intermediate step from Kohn is supported first by the plurality nature of Justice Roberts' opinion. Chief Justice Bell's concurrence relied exclusively on the landowner's interests in being free from unreasonable governmental regulation and avoided mention of the regional duties discussed by Justice Roberts' plurality opinion. Moreover, the two dissenting opinions stressed that they disagreed with the plurality in terms of allocating the burden of proof. For example, Justice Jones argued that it was plaintiff's obligation to prove that the zoning legislation under attack was arbitrary, thereby overcoming the presumption of validity that normally attaches to regulatory measures. Id. at 486-89, $268 \mathrm{~A} .2 \mathrm{~d}$ at 774-75.

The plurality opinion itself lends support, to this interpretation. In dismissing purported rationales for the two and three acre minima other than potential sewage problems, Justice Roberts called them "so clearly makeweights as to barely require comment." $I d$. at $472 \mathrm{n} .5,268 \mathrm{~A} .2 \mathrm{~d}$ at 767 n.5. There is other evidence that the plurality thought the township's alleged justifications were mere shams for an impermissible exclusionary motive. For example, it labeled "patently ridiculous" the argument that large lot zoning was needed for proper on-site sewerage. Id. at 476 , $268 \mathrm{~A} .2 \mathrm{~d}$ at 769 . Cf. id. at $486,268 \mathrm{~A} .2 \mathrm{~d}$ at 774 . (Jones, J., dissenting) (by implication). Justice Roberts painstakingly discussed and sought to refute as disingenuous the township's sewage rationale by presenting materials from state regulations about percolation rates. His conclusion was that "[i]t is obviously sheer fantasy for the township to claim that, because of an on-site sewerage problem, houses cannot be built on a one acre lot, but can be built on a three acre lot." Id. at 478, 268 A.2d at 770 . From this detailed analysis, the plurality concluded that the township's actions were " $[t]$ hinly veiled justifications for exclusionary zoning" which could not be countenanced by the court. Id.

The court's emphasis on the apparently exclusionary purposes behind the two and three acre lot size requirements suggests that the effect standard articulated in Kit-Mar Builders served a burden-shifting function, and that the plurality was not persuaded that the township could justify its zoning regulations on nonexclusionary grounds. The dissenters declined to permit a showing 
lished. At least it seemed plausible that rebuttal evidence on purpose or intent would be relevant if presented on behalf of the locality. To be sure, the scope of permissible purposes was narrow, so the circle of discretion was selfevidently closing in that sense. But at least Kit-Mar Builders left open the inference that a community's motivation was germane on the issue of liability.

In Township of Willistown $v$. Chesterdale Farms, Inc. ${ }^{74}$ the Pennsylvania Supreme Court moved a step closer to establishing an effect standard as a substantive requirement rather than as a burden-shifting evidentiary device. It did this by expanding on its earlier decision in Appeal of Girsh ${ }^{75}$ and by adopting the "fair share" concept as it had been developed several months earlier by the New Jersey Supreme Court in the well known decision, Southern Burlington County NAACP v. Township of Mt. Laurel. ${ }^{76}$

Chesterdale Farms was bought by a developer who sought to build apartments on a tract of land not zoned for apartments. ${ }^{77}$ Initially, the township had not provided for any apartment zones; the developer's proposal to build them was accordingly rejected by the town. ${ }^{78}$ Subsequently, the Pennsylvania Supreme Court ruled in the Girsh ${ }^{79}$ case that a suburban community's land use plan which did not provide for apartments was unreasonable and therefore invalid. In response to Girsh, Willistown Township rezoned 80 acres (out of the township's 11,589 acres) to permit apartment dwellings. Chesterdale Farms' land was unaffected by the rezoning, and it argued successfully that the rezoning of 80 acres was "tokenism" and thereby violated the principle announced in Girsh. ${ }^{80}$

In sustaining the developer's challenge, the court adopted the "fair share" standard, imposing on a community an affirmative duty in its land use plan to provide for prospective regional housing needs by permitting a variety of housing choices to current or prospective residents. ${ }^{81}$ The court concluded that the allocation of 80 out of 11,589 acres for apartments was "exclusionary" in that it did not provide for a fair share of the township acreage for

of effect to alter the traditional allocation of the burden of proof, which required a plaintiff to overcome the presumption of validity that attaches to governmental action. Kit-Mar Builders, therefore, does seem to stop short of adopting the form of effect test that would make rebuttal evidence concerning purpose immaterial. On the other hand, however, it became clear after KitMar Builders that the range of permissible goals a local government could pursue in the land use area was extraordinarily circumscribed in Pennsylvania.

74. 462 Pa. 445, 341 A.2d 466 (1975).

75. $437 \mathrm{~Pa} .237,263$ A.2d 395 (1970) (holding invalid a zoning ordinance which totally excluded apartments from a township).

76. 67 N.J. 151,336 A.2d 713 (1975).

77. $462 \mathrm{~Pa}$. at $447,341 \mathrm{~A} .2 \mathrm{~d}$ at 467 .

78. Id.

79. Appeal of Girsh, $437 \mathrm{~Pa} .237,263$ A.2d 395 (1970).

80. $462 \mathrm{~Pa}$. at $447,341 \mathrm{~A} .2 \mathrm{~d}$ at 467 .

81. Id. at 448-50, 341 A.2d at 468 . 
apartment construction. ${ }^{82}$ The Pennsylvania court was circumspect in its discussion of fair share and, unlike the New Jersey court from which it borrowed the term, ${ }^{83}$ made little effort to refine its meaning. No definition was set out and virtually no mode of analysis for future cases was articulated. Nevertheless, the expansion of the Girsh rule on barring total exclusion of apartments and the adoption of the regional fair share language were strong indications that a new type of effect analysis was evolving. In Chesterdale Farms the court seemed to focus on outcomes that it deemed unacceptable, namely what it considered a practice of "selective admission"84 and a concomitant failure to shoulder a responsibility to accommodate regional growth needs. Since, as the dissent noted, there was not "any evidence of a purpose to exclude apartments permanently from other portions of the municipality,"85-a point unchallenged by the court's opinion-one could fairly conclude that good faith would be insufficient to rebut evidence of exclusionary effect.

In that way Chesterdale Farms, albeit implicitly, seemed to have altered subtly an important effect rationale adopted in Kit-Mar Builders. It marked the beginning of a transformation in Pennsylvania from the use of effect as an inference of improper purpose to the use of effect as evidence, standing alone, of a violation of an evolving regional fair share duty.

What was implicit in Chesterdale Farms became explicit in Surrick v. Zoning Hearing Board. ${ }^{86}$ In Surrick a developer whose land was located in a district zoned for single-family residences sought to build apartments and townhouses. The community's business (B) zone permitted construction of apartments, but only 43 of a total 3,800 acres in the township (1.14\%) were in the B zone. ${ }^{87}$ The existing B zone was "already substantially developed"88 and "multi-family dwellings [were] only one of more than a dozen other uses permitted on this fraction of land." 89 Although there was no total exclusion of apartments, the court concluded that the locality had not met its regional "fair share" duty to provide land for multi-family dwellings.

In Surrick the court's analysis acknowledged explicitly that "evidence of ex-

82. Id.

83. For further discussion of the New Jersey decisions, see Section III.B. infra.

84. $462 \mathrm{~Pa}$. at $449,341 \mathrm{~A} .2 \mathrm{~d}$ at 468 .

85. Id at 452, 341 A.2d at 469 . The dissent found no exclusionary intent but "a bona fide undertaking to bring the Township zoning structure into harmony with the Court's decision in Girsh Appeal ..." Id. at 452 n.4, 341 A.2d at 469 n.4 (citation omitted). Justice Pomeroy characterized the rezoning of 80 acres as "a first step in providing for apartments in an orderly fashion." Id. at $452,34 \mathrm{l} \mathrm{A.2d} \mathrm{at} 470$. Since this rezoning was consistent with overall county plans for redevelopment, and other land could be rezoned as the community continued to grow, the court could not properly act as a "super board of adjustment." Id.

86. 476 Pa. 182, 382 A.2d 105 (1977).

87. Id. at $187,382 \mathrm{~A} .2 \mathrm{~d}$ at 107 .

88. Id.

89. Id. at $195,382 \mathrm{~A} .2 \mathrm{~d}$ at 111 . 
clusionary motive or intent, whether direct or circumstantial, is not of critical importance." 90 Although the Chesterdale Farms opinion did not clearly negate the importance of impermissible purposes in an exclusionary zoning case, Justice Nix in Surrick matter-of-factly noted that Chesterdale Farms "marked an implicit departure away from judicial inquiry into the motives underlying a particular zoning ordinance." 91 Support for that view came from the opinion of a lower court judge in Chesterdale Farms that the exclusionary impact was a result of inadvertence, not design. ${ }^{92}$ However, in Chesterdale Farms the lack of a showing of intent to exclude was only mentioned in Justice Pomeroy's dissent $^{93}$ and not relied on by the court.

Nevertheless, the Surrick case reflects the Pennsylvania court's explicit transformation of the effect rationale from an evidentiary tool for overturning the normal presumption of validity in zoning matters into a free standing substantive doctrine. As Justice Nix said, after Surrick the court's "primary concern" would be "centered upon an ordinance's exclusionary impact," ${ }^{94}$ which will be determined by the extent of the exclusion in relation to community land availability and regional housing needs. ${ }^{95}$ As in Kit-Mar Builders, the Pennsylvania court subtly added an important element to its approach in suburban land use control challenges without forthrightly acknowledging what was happening. ${ }^{96}$ In each situation the movement to facilitate landowner challenges to suburban land use restrictions represented a significant expansion of prior doctrine, and the development was downplayed either by ignoring the matter ${ }^{97}$ or making explicit something an earlier case had done "implicit[ly]."98 In neither situation was the rationale for expansion or the consequence of expansion addressed since the expansion was treated as a fait accompli by an earlier decision. ${ }^{99}$

90. Id. at $192,382 \mathrm{~A} .2 \mathrm{~d}$ at 110 .

91. Id. at $193,382 \mathrm{~A} .2 \mathrm{~d}$ at $110-11$.

92. Id. at $193, \mathrm{n} .10,382 \mathrm{~A} .2 \mathrm{~d}$ at $110 \mathrm{n} .10$.

93. 462 Pa. at 451-52 n.4, $341 \mathrm{~A} .2 \mathrm{~d}$ at $469 \mathrm{n} .4$. The dissent is discussed in note 85 supra.

94. $476 \mathrm{~Pa}$. at $193,382 \mathrm{~A} .2 \mathrm{~d}$ at 111 .

95. Id. at $194,382 \mathrm{~A} .2 \mathrm{~d}$ at 111 .

96. Indeed, at the very end of his opinion, Justice Nix seemed to deny what the court had done by reaffirming the presumption of validity that attaches to any challenged zoning ordinance. $I d$. at $195 \mathrm{n} .13,382 \mathrm{~A} .2 \mathrm{~d}$ at $112 \mathrm{n} .13$. He further noted, however, that the presumption is rebuttable and will not foreclose review of constitutional issues. Id. Apparently this initial presumption is reversed when an impermissible, exclusionary impact is found, for "[w]here, as in the instant case, the facts show an obvious dearth of land zoned as available for multi-family dwellings, the proponents of the zoning ordinance must put forth adequate justification for this zoning-created scarcity." Id. Perhaps this is an oblique suggestion that an overriding substantive governmental objective would satisfy the court. See note 50 supra.

97. See text accompanying notes 61-73 supra.

98. That was done in Surrick, $476 \mathrm{~Pa}$. at 193, $382 \mathrm{~A} .2 \mathrm{~d}$ at 111 (1977).

99. For a similar treatment of precedent by the New York Court of Appeals, see Berenson $v$. Town of New Castle, 38 N.Y. 2d 102, 341 N.E.2d 236, 378 N.Y.S.2d 672 (1975) (construing Dowsey v. Village of Kensington, 257 N.Y. 221, 177 N.E. 427 (1931)). Berenson is discussed in the 
In summary, the evolution of cases in Pennsylvania from Kohn ${ }^{100}$ (1965) to Surrick (1977) ${ }^{101}$ represents a growing sensitivity to regional needs for housing and to a suburban community's duty to nonresidents to make land available through its land use regulation to accommodate its regional fair share of housing and population growth. ${ }^{102}$ At first, the court narrowed the range of permissible purposes, holding invalid the formerly acceptable goals of preserving the character of a community or zoning solely for fiscal ends. ${ }^{103}$ Then, the court permitted evidence of exclusionary effect to reverse the general presumption of validity normally attaching to governmental land use restrictions. Under that formulation, it seemed that localities could present evidence of good faith to refute a plaintiff's prima facie case, even if the range of permissible purposes was narrow indeed. Finally, after Chesterdale Farms and Surrick, the court has established a hazily defined regional fair share duty as a substantive standard, departure from which cannot be excused by rebuttal evidence of good faith intent. It is now appropriate to compare the Pennsylvania substantive standard with the cases decided in New Jersey and then with those decided in New York and California.

\section{B. New Jersey}

The Pennsylvania "fair share" 104 cases build generally on the foundation laid by the Kohn case, which established a suburban community's duty to accommodate population growth. ${ }^{105}$ However, the specific regional fair share concept was drawn from New Jersey's seminal Mt. Laurel decision. ${ }^{106}$

New Jersey had permitted communities to justify zoning schemes for years as furthering the character of the local community. ${ }^{107}$ In dissenting from a decision that upheld a locality's total exclusion of mobile homes, ${ }^{108}$ Justice Hall wrote eloquently of the socioeconomic impact that resulted from such ex-

text accompanying notes 242-46 infra. Cf. Hudgens v. NLRB, 424 U.S. 507 (1976) (construing Lloyd Corp. v. Tanner, 407 U.S. 551 (1972)).

100. 419 Pa. 504, 215 A.2d 597 (1965).

101. $476 \mathrm{~Pa} .182,382$ A.2d 105 (1977).

102. See generally Comment, The Pennsylvania Supreme Court and Exclusionary Suburban Zoning: From Bilbar to Girsh-A Decade of Change, 16 VILL. L. REv. 507 (1971).

103. Cf. Bilbar Constr. Co. v. Board of Adjustment, 393 Pa. 62, 141 A.2d 851 (1958) (holding valid a one acre minimum lot zoning requirement and stating that consideration of general welfare alone would justify an ordinance, as long as the ordinance was not arbitrary, unreasonable or confiscatory).

104. See Section III.A. supra.

105. National Land and Inv. Co. v. Kohn, 419 Pa. 504, 215 A.2d 597 (1965).

106. Southern Burlington County NAACP v. Township of Mt. Laurel, 67 N.J. 151, 336 A.2d 713 (1975), appeal dismissed, 414 U.S. 12 (1975).

107. See, e.g., Vickers v. Township Comm. of Gloucester Township, 37 N.J. 232, 181 A.2d 129 (1962), appeal dismissed, 371 U.S. 233 (1963); Pierro v. Baxendale, 20 N.J. 17, 118 A.2d 401 (1955); Lionshead Lake v. Township of Wayne, 10 N.J. 165, 89 A.2d 693 (1952), appeal dismissed, 344 U.S. 919 (1953).

108. Vickers v. Township Comm. of Gloucester Tnshp., 37 N.J. 232, 181 A.2d 129 (1962). 
clusionary measures. ${ }^{109}$ Thirteen years after his classic Vickers dissent, Justice Hall was able to write his views on exclusionary zoning into New Jersey law by authoring the $M t$. Laurel opinion (1975) for a unanimous court. ${ }^{110}$

In Mt. Laurel, the township of 11,221 population and 14,000 acres had 65 percent of its land vacant. The rate of population increase was dramatic, doubling each decade during the 1950-70 period. ${ }^{11}$ The industrial zone consisted of almost 30 percent of the total land, but that was little utilized. ${ }^{12}$ Of the 10,000 acres (70 percent) zoned for residential purposes, 3,000 were zoned for quarter-acre lots and 7,000 for half-acre lots. The residential zoning categories established minimum lot area and width and dwelling floor area requirements. ${ }^{13}$

The court accepted the township's position that the land use pattern was not intended or designed to exclude newcomers on the basis of "race, origin or believed social incompatibility."114 What was intended, however, was to encourage a "selective type of growth" 115 whose objective was to minimize the local property tax burden. That is, the township, consistent with the policies of other developing communities, employed its land use regulatory authority to control the growth of public expenditures and encourage the development of ratables that yield tax revenues. Since public education is by far the largest single local government expenditure, the strategy was to keep population density reasonably low; as a consequence, apartments or other less expensive rental accommodations were made unavailable.

In $M t$. Laurel the New Jersey court did not face the excessively large lot sizes involved in the earlier Pennsylvania cases. Moreover, the evidence would have supported a finding that the actions of the township were a deliberate effort to act "in its own selfish and parochial interest and in effect build[] a wall around itself to keep out those people or entities not adding favorably to the tax base. ." 116 While the groundwork for an intent analysis-parallelling

109. Id. at 263-66, $181 \mathrm{~A} .2 \mathrm{~d}$ at $146-47$ (Hall, J., dissenting). See Town of Glocester v. Olivo's Mobile Home Court, Inc., 111 R.I. 120, 300 A.2d 465 (1973).

110. Southern Burlington County NAACP v. Township of Mt. Laurel, 67 N.J. 151, 336 A.2d 713 (1975). Although the entire court concurred in the result, Justices Mountain and Pashman filed separate opinions.

In what can only be charitably described as an oversight, Justice Hall in his Mt. Laurel opinion did not so much as cite his Vickers dissent. He merely mentioned the Vickers majority as support for the proposition that although the court historically had sanctioned "a broad measure of restrictive municipal decisions," $i d$. at $176,336 \mathrm{~A} .2 \mathrm{~d}$ at 726 , it had also warned "of the inevitability of change in judicial approach and view as mandated by the world around us." Id. Justice Pashman's concurrence did note the significance of the earlier dissent. Id. at 194, 336 A.2d at 735-36 (Pashman, J., concurring).

111. Id. at $161-62,336 \mathrm{~A} .2 \mathrm{~d}$ at 718 .

112. Id. at $162-63,336$ A.2d 719 .

113. Id. at 163-64, $336 \mathrm{~A} .2 \mathrm{~d}$ at $719-20$.

114. Id. at $159,336 \mathrm{~A} .2 \mathrm{~d}$ at 717 .

115. Id. at $170,336 \mathrm{~A} .2 \mathrm{~d}$ at 723 (quoting the record of the trial court).

116. Id. at $171,336 \mathrm{~A} .2 \mathrm{~d}$ at 723 . 
the Kohn approach-was available, Justice Hall explicitly eschewed that approach, noting that "the identical [analytical] conclusion follows even when municipal conduct is not shown to be intentional, but the effect is substantially the same as if it were." 117 Thus, the Mt. Laurel court based its decision invalidating the land use scheme on an effect analysis.

Given the relatively small lot size requirement involved, the $\mathrm{Mt}$. Laurel decision is a striking example of a court's adoption of a substantive duty as a standard by which to measure the legality of a local zoning scheme. While the Pennsylvania court articulated a concern with the exclusion of uses (e.g., apartments), ${ }^{118}$ the New Jersey court placed emphasis on the exclusionary impact on low-income people. ${ }^{119}$ The court reasoned that the state's police power, which can be delegated to local governmental units, must be exercised in furtherance of the general welfare. The question, of course, is "whose general welfare must be served or not violated in the field of land use regulation." 120 The court concluded that since "the zoning power is a police power of the state and the local authority is acting only as a delegate of that power and is restricted in the same manner as the state...., when regulation does have a substantial external impact, the welfare of the state's citizens beyond the borders of the particular municipality cannot be disregarded and must be recognized and served."121

Thus, a local government unit has an obligation to accommodate regional interests. Justice Hall found shelter to be a basic human need and a fundamental part of the general welfare concept. ${ }^{122}$ Since localities have regional responsibilities to promote the general welfare and since housing is a component of the general welfare concept, it followed that localities have a duty through their land use plan to "make realistically possible an appropriate variety and choice of housing." 123

In refining the nature of a locality's regional housing obligation, Justice Hall identified several elements. First, the analysis seemed limited to a "developing municipality," which was not precisely defined. ${ }^{124}$ Second, the duty was described as "presumptive." 125 The presumptive duty had both procedural and substantive elements. The procedural obligation was described as follows:

117. Id. at 174 n. 10,336 A.2d at 725 n. 10 .

118. Surrick v. Zoning Hearing Bd., 476 Pa. 182, 193 n.10, 382 A.2d 105, 110 n.10 (1977).

119. $67 \mathrm{~N} . \mathrm{J}$. at $173,336 \mathrm{~A} .2 \mathrm{~d}$ at 724 .

120. Id. at $177,336 \mathrm{~A} .2 \mathrm{~d}$ at 726 (emphasis in original).

121. Id.

122. Id. at $178-79,336 \mathrm{~A} .2 \mathrm{~d}$ at 727 . This contrasts with the approach taken by the federal courts, both substantively, see Lindsey v. Normet, 405 U.S. 56, 74 (1972), and analytically, see San Antonio Ind. School Dist. v. Rodriguez, 411 U.S. 1, 33 (1973). See generally, Ely, Foreword: On Discovering Fundamental Values, 92 HaRv. L. REv. 5 (1978).

123. 67 N.J. at $174,336 \mathrm{~A} .2 \mathrm{~d}$ at 724 .

124. Id. at $173,336 \mathrm{~A} .2 \mathrm{~d}$ at 724 .

125. Id. at $174,180,336 \mathrm{~A} .2 \mathrm{~d}$ at 724,728 . 
... [W] hen it is shown that a developing municipality in its land use regulation has not made realistically possible a variety and choice of housing, including adequate provision to afford the opportunity for low and moderate income housing or has expressly prescribed requirements or restrictions which preclude or substantially hinder it, a facial showing of violation of substantive due process or equal protection under the state constitution has been made out and the burden, and it is a heavy one, shifts to the municipality to establish a valid basis for its action or non-action. ${ }^{126}$

The substantive aspect concerned what factors establish a burden-shifting prima facie case and what defenses support the municipality's actions. These were not spelled out other than to note that justifications "may well vary between municipalities according to peculiar circumstances." 27

The third element of the regional duty had both affirmative and negative aspects. ${ }^{128}$ Each developing community had "affirmatively to plan and provide, by its land use regulations, the reasonable opportunity for an appropriate variety and choice of housing, including of course, low and moderate cost housing, to meet the needs, desires and resources of all categories of people who may desire to live within its boundaries." 129 That is, the developing municipality must plan to accommodate its "fair share of the present and prospective regional need." 130 On the negative side, a developing community "may not adopt regulations or policies which thwart or preclude that opportunity."131

Applying the standards announced to the Mt. Laurel situation, Justice Hall concluded a prima facie case was established because of the limited type of homes permitted, the minimum lot and floor size requirements, and the large amount of land zoned industrial compared to its very low level of utilization. ${ }^{132}$ In response to the municipality's fiscal zoning rationale, the court sustained fiscal concerns as a legitimate zoning purpose. However, a fiscal rationale is insufficiently weighty to justify the exclusionary effect of excluding or limiting categories of housing from a community. ${ }^{133}$

With respect to the municipality's ecological argument, the court also found environmental protection objectives to be permissible. However, "the danger and impact must be substantial and very real ...-not simply a makeweight to support exclusionary housing measures or preclude growth-and the regulation adopted must be only that reasonably necessary for public protection of a vital interest." ${ }^{134}$

126. Id. at $180-81,336 \mathrm{~A} .2 \mathrm{~d}$ at 728 (citation omitted).

127. Id. at $181,336 \mathrm{~A} .2 \mathrm{~d}$ at 728 .

128. Id. at $179-80,336 \mathrm{~A} .2 \mathrm{~d}$ at 728 .

129. Id. at $179,336 \mathrm{~A} .2 \mathrm{~d}$ at 728 .

130. Id. at $174,336 \mathrm{~A} .2 \mathrm{~d}$ at 724 .

131. Id. at $180,336 \mathrm{~A} .2 \mathrm{~d}$ at 728 .

132. Id. at $183-85,336 \mathrm{~A} .2 \mathrm{~d}$ at $729-30$.

133. Id. at $185-86,336 \mathrm{~A} .2 \mathrm{~d}$ at 731 .

134. Id. at $187,336 \mathrm{~A} .2 \mathrm{~d}$ at 731 . See note 50 supra. For a discussion of the environmental im- 
In short, what the New Jersey court did in Mt. Laurel was to establish a regional duty on the part of developing communities to bear their "fair share" of regional housing needs, especially for low and moderate income housing. The duty could be used to invalidate local land use regulations either because a community failed to satisfy its affirmative obligation to make sites available or because in some way it actually obstructed the development of low or moderate income housing. Evidence of an exclusionary impact alone was sufficient to shift the burden of justification onto the locality, but the local unit of government could not satisfy its burden merely by showing permissible motivation or legitimate policy objectives. The court accepted as legitimate both the fiscal and ecological purposes proffered by Mt. Laurel. Rather, as in the fundamental interest substantive due process context, ${ }^{135}$ the municipality had to demonstrate both an overriding (not just legitimate) interest and narrowly tailored means of achieving the overriding interest (a less drastic means approach). ${ }^{136}$

The Mt. Laurel opinion raised as many issues as it resolved. ${ }^{137}$ The notion of region was left imprecise as was the concept of "fair share." Similarly, there was an air of unreality about the "fair share" concept because government through land use controls does not construct housing for low and moderate income persons. Such housing typically requires some form of public or private subsidy to be viable. After $M t$. Laurel one was left to wonder whether the locality's duty extended to an obligation to provide housing directly for underserved population groups. Other forms of regulation-building codes, subdivision regulations-affect the cost of and, therefore, the accessibility of housing to low and moderate income groups. Thus, would a community be required to forgo fireproofing or water down other required, but costly, fire prevention features of new housing in the name of regional fair share? Would expensive mandatory water and sewer hook ups fall before the regional housing duty? ${ }^{138}$

pact of Mt. Laurel, see Ackerman, The Mount Laurel Decision: Expanding the Boundaries of Zoning Reform, 1976 U. ILL. L. F. 1, 43-71.

135. $C f$. Roe v. Wade, 410 U.S. 113, 155 (1973) (regulation affecting the fundamental right of privacy can only be justified by a compelling state interest and legislation must be narrowly drawn to promote only the compelling state interest).

136. The analytical method of the federal cases involving substantive due process is summarized in McCoy, Recent Equal Protection Decisions-Fundamental Right to Travel or "Newcomers" as a Suspect Class?, 28 VAND. L. REv. 987, 988-95 (1975).

137. Commentators have been quick to seize on this point. See, e.g., Ackerman, note 134 supra; Mallach, Do Lawsuits Build Housing?: The Implications of Exclusionary Zoning Litigation, 6 RuT.Cам. L.J. 653 (1975); Payne, Delegation Doctrine in the Reform of Local Government Law: The Case of Exclusionary Zoning, 29 Rutgers L. REv. 803 (1976); Rose, Exclusionary Zoning and Managed Growth: Some Unresolved Issues, 6 Rut.-CAM. L.J. 689 (1975); Note, The Inadequacy of Judicial Remedies in Cases of Exclusionary Zoning, 74 Mich. L. REv. 760 (1976); Note, Exclusionary Zoning and Timed Growth: Resolving the Issue After Mount Laurel, 30 RuTGERs L. REv. 1237 (1977).

The New Jersey Court has not been unaware of the extensive discussion triggered by Mt. Laurel. Oakwood at Madison, Inc. v. Township of Madison, 72 N.J. 481, 495 n.3, 371 A.2d 1192, 1198 n.3, (1977).

138. Cf. Robinson v. City of Boulder, 190 Colo. 357, 547 P.2d 228 (1976) (holding that a city 
In short, the $M t$. Laurel decision left unanswered questions concerning every facet of the fair share obligation. Did Mt. Laurel entirely overturn the presumption of validity in land use challenges, or was its analytical framework limited to specific types of communities? What showing constituted a prima facie case of exclusion, thereby shifting the burden of justification to the local government? What local interests would be deemed sufficiently important to outweigh the regional fair share duty?

Subsequent New Jersey decisions have provided insights into some of these questions raised in Mt. Laurel. In Pascack Association, Ltd. v. Mayor of Washington ${ }^{139}$ the court considered the issue of whether Mt. Laurel's regional fair share duty extended to all municipalities. ${ }^{140}$ Backing away from the broader implications of $M t$. Laurel, ${ }^{141}$ the court held that the regional fair share duty does not apply to a community that is "developed substantially fully upon detached single-family dwellings," 142 even if the community makes no provision for multifamily dwellings. The Mt. Laurel approach was confined to situations where the municipality is "developing"143 and where the housing effectively excluded was intended directly for low and moderate income people. ${ }^{144}$

In Pascack the court declined to adopt a per se principle mandating zoning for multi-family housing by every local unit of government "regardless of its circumstances with respect to degree or nature of development."145 Indeed, outside the context of a "developing" locality, the court reaffirmed its pre- $M t$. Laurel endorsement of "maintaining the character of a fully developed, predominantly single-family residential community" 146 as a legitimate zoning objective. Consequently, if a substantially developed community chooses to exclude multifamily housing in order to preserve its single-family character, it can validly do so under Pascack, even if there is concededly a general regional shortage of multifamily housing. ${ }^{147}$

acting as a public utility may not refuse to extend water and sewer services beyond its geographical limits in an attempt to control land use and population growth in that area).

139. 74 N.J. 470,379 A.2d 6 (1977).

140. Id, at $473-74,379 \mathrm{~A} .2 \mathrm{~d}$ at 7 .

141. The court in Pascack followed the trend of retrenchment begun in Oakwood at Madison, Inc. v. Township of Madison, 72 N.J. 481, 371 A.2d 1192 (1977). See text accompanying notes 153-9 I infra. Justice Hall retired before either Pasack or Oakwood at Madison were written. Both were authored by a temporarily assigned justice.

142. 74 N.J. at $474,379 \mathrm{~A} .2 \mathrm{~d}$ at 8 .

143. Id, at 480,379 A. $2 \mathrm{~d}$ at 11 .

144. Id. There is an interesting tension between this requirement and the theory of supply and demand-a "filter-down" theory-adopted in Oakwood at Madison. See note 161 infra.

145. Id. at $481,379 \mathrm{~A} .2 \mathrm{~d}$ at 11 .

146. Id. at $483,379 \mathrm{~A} .2 \mathrm{~d}$ at 13 .

147. Id. at 485-86, 379 A.2d at 13-14. Accord, Fobe Associates v. Mayor of Demarest, 74 N.J. 519, 526-27, 379 A.2d 31, 35 (1977). See also Montgomery Associates v. Township of Montgomery, 149 N.J. Super. 536, 374 A.2d 86 (Super. Ct. Law Div. 1977). For an example of a state court which expressly overruled an earlier decision that had forbidden a community from totally 
What Pascack and the contemporaneous decision in Fobe Associates v. Mayor of Demarest ${ }^{148}$ indicate is that $M t$. Laurel altered the judicial standard of review in New Jersey only where a "developing" municipality is involved and where the direct beneficiaries of a proposed project are low and moderate income persons. Otherwise, the traditional restrained standard of review controls -prohibiting "arbitrariness or patent unreasonableness" and requiring a "substantial relation" between the regulation and the government's permissible police power purposes. ${ }^{149}$ Where the threshold Mt. Laurel criteria are not met, the Pascack court expressed clearly its disinclination

to substitute [its] conception of what the public welfare requires by way of zoning for the views of those in whom the Legislature and the local electorate have vested that responsibility. The judicial role is . . . limited to the assessment of a claim that the restrictions of the ordinance are patently arbitrary or unreasonable or violative of the statute, not that they do not match the plaintiff's or the court's conception of the requirements of the general welfare, whether within the town or the region. ${ }^{150}$

While the court was "not insensitive to the current social need for larger quantities of affordable housing of all kinds for the general population," 151 it suggested a legislative remedy because the courts are "not suited to the role of an ad hoc super zoning legislature, particularly in the area of adjusting claims for satisfaction by individual municipalities of regional needs, whether as to housing or any other important social need affected by zoning . . . The problem is not an appropriate subject of judicial superintendence." 152

While Pasack reflects a sharp categorizational circumscription of the $M t$. Laurel analytical approach, ${ }^{153}$ the court's decision in Oakwood at Madison, Inc. $v$. Township of Madison ${ }^{\mathbf{1 5 4}}$ was an attempt to clarify the meaning of and apply the $M t$. Laurel analytical framework.

The New Jersey Supreme Court in Oakwood at Madison was dealing with an "archetypal 'developing' municipality within the contemplation of . . . Mt. Laurel,"155 and was obliged to apply the Mt. Laurel analytical mode, but the

excluding multifamily residences, see McDermott v. Village of Calverton Park, 454 S.W.2d 577 (Mo. 1970).

148. 74 N.J. 519,379 A.2d 31 (1977).

149. 74 N.J. at 483,379 A.2d at 12 .

150. Id. at $485,379 \mathrm{~A} .2 \mathrm{~d}$ at 13 .

151. Id. at 487,379 A.2d at 14 .

152. Id. at $487-88,379 \mathrm{~A} .2 \mathrm{~d}$ at 15 .

153. For a discussion of this interesting technique for narrowing the reach of a doctrine, see Blumstein, Some Intersections of the Negative Commerce Clause and the New Federalism: The Case of Discriminatory State Income Tax Treatment of Out-of-State Tax-Exempt Bonds, 31 VAND. L. REV. 473, 488 n.60 (1978); Ely, Flag Desecration: A Case Study in the Roles of Categorization and Balancing in First Amendment Analysis, 88 HARv. L. Rev. 1482 (1975).

154. 72 N.J. 481, 371 A.2d 1192 (1977).

155. Id. at $501,371 \mathrm{~A} .2 \mathrm{~d}$ at 1201 . 
court was uncomfortable with its self-assigned role in implementing $M t$. Laurel. The court made "explicit" what had only been "adumbrated" in Mt. Laurel, "that the governmental-sociological-economic enterprise of seeing to the provision and allocation throughout appropriate regions of adequate and suitable housing for all categories of the population is much more appropriately a legislative and administrative function rather than a judicial function to be exercised in the disposition of isolated cases." 156 Nevertheless, "[i]n the absence of legislation providing for regional zoning authorities," 157 the court enforced the $M$ t. Laurel principles in the context of a developing community's failure to provide for substantial multi-family or single-family residences accessible to lower income groups.

Some of the questions raised by Mt. Laurel were addressed more definitively in Oakwood at Madison. The mechanism by which affordable housing could become available to lower income groups was clarified. The court declined to impose an affirmative obligation on developing communities to create additional lower income housing directly. The $M t$. Laurel affirmative duty did not require the actual construction or sponsorship of housing projects, nor did it require tax concessions or zoning bonuses tied to rental or sale price concessions for the benefit of prospective lower income persons. ${ }^{158}$ Despite its recognition that the unsubsidized private sector would not "construct new housing affordable by the low income population and by a large proportion of those of moderate income," 159 the court rejected the contention that "the mandate of Mount Laurel is impracticable in the current economy and that litigation to enforce it is futile." ${ }^{160}$ The court identified the filter down theory ${ }^{161}$ as the "only acceptable alternative recourse"162 for private construction of lower income housing. The filter down rationale is that, absent direct or indirect subsidization, the only effective or realistic way to increase lower income housing opportunities is to encourage overall increases in the housing stock. As middle income families move into new units, existing units will become available to lower income groups who could not afford the new units. ${ }^{163}$ In

\footnotetext{
156. Id. at $534,371 \mathrm{~A} .2 \mathrm{~d}$ at 1218 .

157. Id. at 495,371 A.2d at 1198 .

158. Id. at 546, $37 \mathrm{l} \mathrm{A.2d} \mathrm{at} 1224$.

159. Id. at $510,371 \mathrm{~A} .2 \mathrm{~d}$ at 1206 .

160. Id. at $512,371 \mathrm{~A} .2 \mathrm{~d}$ at 1207 .

161. An extensive review of filtration theory is found in W. GrigsBy, Housing MARKETS AND Public Policy 84-I30 (1963). See also C. Hartman, Housing and Social Policy 62-63 (1975); J. Lansing, C. Clifton \& J. Morgan, New Homes and Poor People: A Study of Chains of Moves (1969); Fisher and Winnick, A Reformulation of the "Filtering" Concept, $7 \mathrm{~J}$. of Soc. Issues 47

162. 72 N.J. at $512,371 \mathrm{~A} .2 \mathrm{~d}$ at 1207.

163. See W. GrigsBy, supra note 161, at 100-01.

Within an overall housing market, the filter down approach makes some sense, assuming of course that supply availability does not in turn generate its own dèmand. If there is a relatively
} (1951). 
adopting the filter down rationale the court was obliged to modify some of the $M t$. Laurel language. Since $M t$. Laurel would not be extended to an obligation to sponsor or subsidize lower income housing construction directly, the court's exclusive focus in Oakwood at Madison was the community's pattern of land use regulation. Consistent with that orientation, the court concluded that the shorter the filtering process the better. Thus, it imposed on a growing municipality the duty "to adjust its zoning regulations so as to render possible and feasible the 'least cost' housing, consistent with minimum standards of health and safety, which private industry will undertake, and in amounts sufficient to satisfy the deficit in the hypothesized fair share."164 Thus, under Oakwood at Madison the concept of "least cost" replaced the notion of "low and moderate income" housing, at least as part of a developing community's fair share duty to accommodate its land use regulations to regional housing needs.

The Oakwood at Madison court also clarified what constitutes a prima facie case of exclusion. In $M t$. Laurel the court had criticized bedroom restrictions as exclusionary. ${ }^{165}$ In Oakwood at Madison the court considered bulk and density regulations in areas permitting multifamily dwellings to be exclusionary because, given the "economics of building," mix of 80 percent one bedroom and 20 percent two bedroom development. Also exclusionary was "the prima facie disproportion of land zoned for high cost residences vis-à-vis that zoned for lower cost residences and multifamily units." ${ }^{167}$ Especially criticized was the lack of zoning for single-family residences on very small lot sizes. ${ }^{168}$

The exclusionary label was applied in Oakwood at Madison to much more than lot size, bulk and density, or use allocation proportions. It was applied as well to the "undue cost-generating features inherent in the ordinance which raise the expense of purchasing or renting new housing units above the reach of the great majority of the lower income population." ${ }^{69}$ Madison township had amended its ordinance in 1973 to provide for planned unit developments (PUD) and cluster zoning and argued that those provisions satisfied its low

stable population size and mix-rather questionable in the "developing" municipalities to which Mt. Laurel applies-it is reasonable to hypothesize that housing units vacated by middle income persons will become available at relatively affordable prices to lower income persons. However, for any given community, construction of new housing units for middle-income persons does not assure that affordable units within that community will become available for lower income groups. Id. at 129-30. Moreover, from an equitable perspective, there is a body of opinion that undoubtedly would find such a trickle down approach unfair or unacceptably indirect. See, e.g., Mallach, supra note 137 , at 666 n.55.

164. 72 N.J. at $512,371 \mathrm{~A} .2 \mathrm{~d}$ at 1207.

165. 67 N.J. at $182-83,336 \mathrm{~A} .2 \mathrm{~d}$ at 729 .

166. 72 N.J. at $516,371 \mathrm{~A} .2 \mathrm{~d}$ at 1209 .

167. Id. at 515, 37 A.2d at 1209 .

168. Id. at $516,37 \mathrm{l}$ A.2d at 1209 .

169. Id. at $524,371 \mathrm{~A} .2 \mathrm{~d}$ at 1213 . 
and moderate income housing obligation. The court in Oakwood at Madison called the township's position "illusory"170 since various PUD requirements had "the potential for greatly increasing the costs of housing units in that zone."171

In Mt. Laurel the township had had a PUD zone but had repealed it. Despite the repeal, the court went out of its way to condemn the bedroom restrictions because the township could reenact a PUD zone and because "the subject is of importance generally." 172 No other features of the PUD ordinance were discussed as exclusionary, even though the Mt. Laurel attorney apparently conceded at oral argument that some of the conditions imposed on developers might be illegal. ${ }^{173}$

The Oakwood at Madison court found several components of the PUD regulations exclusionary. Consideration of these cost-generating provisions as exclusionary is significant because they clearly circumscribe the ability of local governments to exact concessions from developers to offset incremental costs brought about by subdivision developments. ${ }^{174}$ Although different state courts have developed various tests to determine the validity of subdivision exactions, ${ }^{175}$ the underlying concern has been that the costs imposed on the developer by the municipality be related to the costs imposed by the development on the community. The disagreement among courts on the issue had focused largely on the question of how unique and identifiable the costs imposed by a specific development must be-whether a community can assert that overall development incurs incremental costs and that specific developments can be

170. Id. at 507, $371 \mathrm{~A} .2 \mathrm{~d}$ at 1204-05.

171. Id. at $508,371 \mathrm{~A} .2 \mathrm{~d}$ at 1205 .

172. 67 N.J. at $182-83,336$ A.2d at 729 .

173. Id. at 168 n.6, $336 \mathrm{~A} .2 \mathrm{~d}$ at 722 n.6.

174. This contrasts with the approach of the California Supreme Court, which has recognized that cost-increasing dedication requirements may be exclusionary but nevertheless are justified. See Associated Home Builders v. City of Walnut Creek, 4 Cal. 3d 633, 484 P.2d 606, 94 Cal. Rptr. 630 (1971), appeal dismissed, 404 U.S. 878 (1971). Associated Home Builders is discussed fur. ther in text accompanying notes 263-84 infra.

175. In California exactions must be reasonably related to municipal needs, Ayres v. City Council of Los Angeles, 34 Cal.2d 31, 207 P.2d 1 (1949), while in Illinois they must be specifically and uniquely attributable to the subdivider's activity. Pioneer Trust and Savings Bank v. Village of Mount Prospect, 22 Ill.2d 375, 176 N.E.2d 799 (1961). In New York, Jenad, Inc. v. Village of Scarsdale, 18 N.Y.2d 78, 218 N.E.2d 673, 271 N.Y.S.2d 955 (1966), which follows the Wisconsin rule, Jordan v. Village of Menomonee Falls, 28 Wis.2d 608, 137 N.W.2d 442 (1966), appeal dismissed, 385 U.S. 4 (1966), subdivision exactions are permitted if a municipality must provide more services because of foreseeable increases in subdivision developments generally, even if a need is not solely attributable to a particular subdivision.

These major rules are critiqued by the Florida court in Wald Corp. v. Metropolitan Dade County, 338 So.2d 863 (1976). The Ayres standard is rejected as allowing "local governments almost unlimited discretion in the imposition of dedication requirements." Id. at 866 . Pioneer Trusi, on the other hand, is not acceptable because it "created a standard which is unduly restrictive of local exercises of the police power." Id. The court found the best approach to be the "rational nexus" test of Jordan. 
required to bear an appropriately allocated average share; ${ }^{176}$ or whether, in order to justify an exaction, a community must show incremental costs attributable specifically and uniquely to a particular development. ${ }^{177}$

The Oakwood at Madison court's treatment of the subdivision regulations, therefore, is of especial significance in the growth management context because it concerns the heart of the growth management controversy-whether new growth should pay its own way and bear its fully allocated share of at least the marginal cost attributable to it. ${ }^{178}$ In the Oakwood at Madison opinion, the New Jersey Supreme Court redirected the focus of analysis away from issues of fairness (fiscal equity) to the developer, relying instead on the exclusionary effect of costly subdivision exactions on potential newcomers to the community. In what was labeled a "corollary of Mt. Laurel,"179 the court concluded that "when municipal exactions from developers reach such proportions as to exert an exclusionary influence, whether in a PUD or any other context, they offend the constitutional precept of $\mathrm{Mt}$. Laurel and must be remedied." 180

The three components of Madison's PUD regulations deemed exclusionary were:

(a) the requirement that the developer construct and dedicate to the township a school to accommodate 0.5 children per dwelling unit;

(b) the requirement that the developer provide streets and utility hookups; and

(c) the three step approval process that could take from one to two years. ${ }^{181}$

With regard to the school construction and dedication provision the court cited the estimated cost of constructing complying school facilities and concluded that the costs per unit did "not seem reasonable."182 The only frame

176. This would seem to be the Wisconsin approach as enunciated in Jordan v. Village of Menomonee Falls, 28 Wis.2d 608, 137 N.W.2d 442 (1966).

177. That is the restrictive approach adopted in Illinois. Pioneer Trust and Savings Bank v. Village of Mount Prospect, 22 Ill.2d 375, 176 N.E.2d 799 (1961). For a general discussion of the problem of subdivision exactions, see Heyman \& Gilhool, The Constitutionality of Imposing Increased Community Costs on New Suburban Residents Through Subdivision Exactions, 73 Y ALE L.J. 1119 (1964).

178. For an interesting perspective on the equitable and fiscal factors governing subdivision exaction issues, see Ellickson, supra note 9, at 465-89. According to Ellickson, the critical determinant in imposing exactions should be how similar municipal services were financed in the past. Id. at 478 . If benefits have been financed by general revenue exactions, newcomers should receive similar generally financed benefits. Id. If services historically have been financed by dedication requirements or other forms of special revenue raising, Ellickson would deem similar treatment of newcomers appropriate, despite any exclusionary impact that that might have. Id. Provided that equity among oldtimers and newcomers is achieved, Ellickson's criteria would be satisfied.

179. 72 N.J. at $520,371 \mathrm{~A} .2 \mathrm{~d}$ at 1211 .

180. Id. The Oakwood at Madison rationale would find exclusionary any substantial exactions that impeded development of low-cost housing. Presumably this would be the case even if, under Ellickson's criteria, see note 178 supra, there would be no inequity between existing residents and potential residents. Thus, the New Jersey court is imposing a duty on oldtimers to subsidize newcomers, at least when not to do so would present a fiscal barrier to the entry of newcomers who are of low and moderate income.

181. 72 N.J. at $520-23,371 \mathrm{~A} .2 \mathrm{~d}$ at $1211-13$.

182. Id. at $521,371 \mathrm{~A} .2 \mathrm{~d}$ at 1211 . 
of reference mentioned was a 1964 study of subdivision exactions, wherein the authors found a much lower range of costs per lot to be reasonable. ${ }^{183}$ Strikingly, from the growth management perspective, there was no attempt whatsoever to examine the costs for schooling actually imposed on a community when a new development is constructed. Apparently, the reasonableness of the relationship between the exactions on the developer and the incremental costs imposed by the development on the resources of the community is not the critical analytical variable. Instead, some unarticulated, absolutist notion of the reasonableness of the per unit cost of the proposed exaction is what counts in the determination whether a regulation is exclusionary. ${ }^{184} \mathrm{Im}$ plicitly, then, since the court held that the school construction and dedication requirement "must be omitted in the revision of the ordinance," 185 the Oakwood at Madison decision requires that a community subsidize growth if not doing so would result in exclusion or discouragement of low and moderate income persons from residing in the jurisdiction. ${ }^{186}$

One final feature of the Oakwood at Madison decision bears mention. $M t$. Laurel had announced a developing community's affirmative duty to provide adequate opportunity for low and moderate income housing. Oakwood at Madison declined to extend this affirmative duty to include the direct construction or sponsorship of such housing. It did, however, identify one component of the affirmative obligation: A developing community must provide a density bonus to developers for constructing larger units with three or four bedrooms. ${ }^{187}$ According to the court, this incentive is necessary to overcome the market incentive to construct mainly one bedroom units; ${ }^{188}$ accordingly,

183. Id. at 520, 37। A.2d at 1211 . The study cited was Heyman \& Gilhool, supra note 177, which concluded that the "amount of the exactions at issue in the subdivision cases to date- $\$ 37.50$ per lot, $\$ 50.00$ per lot, $\$ 80.00$ per lot, $\$ 325.00$ per lot-can surely not be characterized as exclusionary." Id. at 1155-56 (footnotes omitted). The New Jersey court estimated the Oakwood at Madison exaction costs to be $\$ 1,275$ per unit. 72 N.J. at 520,371 A.2d at 1211 .

184. See note 180 supra.

185. 72 N.J. at $521,371 \mathrm{~A} .2 \mathrm{~d}$ at 1211 .

186. In addition to the school construction and dedication requirement, the court invalidated street and utility hookup requirements and a three-step building application approval process. Only nine percent of the town's vacant acreage was zoned for PUD, and two-thirds of this land lay in a remote area. The court found an exclusionary impact in the increased costs to multifamily housing and estimated subsequent delays in building the more remote PUDs and ordered that on remand the municipality be directed either to eliminate the requirements or render them non-exclusionary. Id. at 522-23, 371 A.2d at 1212 . The approval process was found to be exclusionary because "a protracted approval process will add greatly to the cost of any project and hence may tend to render development prohibitive to lower income users." Id. at 523, 371 A.2d at 1213. The court ordered the municipality to eliminate one of the three stages. $I d$. at 524,371 A.2d at 1213 .

187. Id. at $517-18,371 \mathrm{~A} .2 \mathrm{~d} 1209-10$.

188. The court concluded that "the maximum bulk and density regulations in the AF and PUD zones... when combined with the economics of building, effectively dictate development on an 80 [percent] one bedroom, 20 [percent] two bedroom mix ..."Id. at 516, 371 A.2d at 1209. 
the court held that a developing municipality "should affirmatively act to encourage a reasonable supply of multi-bedroom units affordable by at least some of the lower income population." ${ }^{189}$ Under the circumstances present in Madison township, the court concluded that such density bonuses were "a vital weapon in the armament of affirmative zoning for adequate housing of families in all income categories," and therefore they were a "necessary implement in the encouragement of builders to provide multifamily housing for those of lower income."190 Consequently, if "necessary to achieve sufficient suitable least-cost housing," the density bonus "keyed to quantitative or bulk concessions by the builder" is a mandatory component of a developing community's affirmative zoning scheme in New Jersey. ${ }^{191}$

\section{IV}

\section{Growth Management: New York and California}

The Pennsylvania and New Jersey cases on exclusionary zoning ${ }^{192}$ reflect a growing sensitivity to the socioeconomic effects of delegating land use regulation authority to local units of government. ${ }^{193}$ The Pennsylvania and New Jersey Supreme Courts emphasized the desirability of considering regional needs in local land use decisions and expressed their hope that appropriate legislation would be forthcoming to establish effective regional planning mechanisms.

The legal doctrines that evolved in those two states were designed to offset the exclusionary impact the courts deemed undesirable. These approaches stressed three related concepts. First, it was unacceptable to allow local units of government in developing communities to legislate solely in their own self interest. Even in the absence of legislation, courts had an obligation to factor

189. Id. at $517.371 \mathrm{~A} .2 \mathrm{~d}$ at 1209 .

190. Id. at $517-18,371 \mathrm{~A} .2 \mathrm{~d}$ at 1210 .

191. Id. at 546-47, $371 \mathrm{~A} .2 \mathrm{~d}$ at 1225 . The sort of density bonus the court approved was, using the opinion's example, for each three or four bedroom unit constructed, permitting an additional single bedroom or efficiency unit above the general density limits. Id. at $517 \mathrm{n} .27,371 \mathrm{~A} .2 \mathrm{~d}$ at 1209 n.27. Since the regulation concerned physical use of land, it was permissible within both the zoning and general police power. Id. at $517,371 \mathrm{~A} .2 \mathrm{~d}$ at 1210 . The question of density bonuses tied to rental or sales price concessions was reserved by the court for the future. Id. at 547, 371 A.2d at 1225. Generally labeled "rent skewing," this type of density bonus encourages a developer to include low and moderate income units either by "requiring that a mandatory percentage of moderately priced dwellings be constructed... or allowing a developer a density bonus enabling him to build, for example, one conventional unit for every two low or moderate income units constructed." Id. at $518 \mathrm{n} .28,371$ A.2d at 1210 n.28. The court believed that local governments probably could not exercise that sort of zoning power without express legislative authorization. Id. at 518, 371 A.2d at 1210. See Board of Supervisors v. DeGroff Enterprises, Inc., $214 \mathrm{Va}$. 235,198 S.E.2d 600 (1973).

192. See Sections III.A. \& III.B. supra.

193. See generally Note, Large Lot Zoning, 78 Y ALE L.J. 1418 (1969). 
regional needs into the process of judicial review. Secondly, the regional focus would be implemented by the imposition of a substantive duty on developing communities to bear their fair share of regional housing needs. Thus, the courts in Pennsylvania and New Jersey undertook to define a substantive affirmative obligation on the part of local governments to make available adequate locations suitable to a wide variety of housing opportunities. The New Jersey court specified examples of cost-increasing regulations that had the impermissible, restrictive effect of limiting construction of least-cost housing. In Pennsylvania and New Jersey proof of a violation of the substantive duty could be mustered by a showing of impact alone; improper purpose was not considered a critical component of proof.

The third concept developed seemed to bar a community from recovering the marginal cost of new development on the ground that if such costs are high they exclude some socioeconomic groups from the community. In effect, this is a requirement that developing communites subsidize ${ }^{194}$ some forms of development because to adopt a "new growth must pay its own way" philosophy will have consequences deemed socially undesirable by the courts.

The New York and California cases on growth control can best be discussed against this background of intense judicial solicitude for the low and moderate income housing needs of a region.

With the rise of the environmental movement, the array of land use restrictions once deemed exclusionary took on another character. ${ }^{195}$ Resource conservation became a widely approved value, and restrictions on rapid suburban growth received a more sympathetic eye from commentators ${ }^{196}$

194. The concept of "subsidy" requires a normative benchmark. The term is generally not applied if government is merely providing a benefit to which an individual or a group is entitled. Professor Ellickson uses as his benchmark the historical method of financing services used by a community. He argues that newcomers are entitled to a level of services commensurate with the level of services enjoyed by oldtimers. He would charge newcomers the marginal cost of new services, provided that that form of special revenue raising was used in the past. Ellickson, supra note 9, at 460-61. See note 178 supra.

Similarly, an "open-up-the-suburbs" proponent, one who takes seriously the affirmative duty of local government to make a wide variety of housing opportunities available, might object to the use of the word "subsidy" because one may not properly characterize as a subsidy something that government is obligated to provide. Services that are appropriately governmental but which are financed by general tax revenues are inevitably a form of subsidy unless they are user-based. And, the argument would run, we do not use the term "subsidy" to describe the provision of, for example, police services in areas that pay a disproportionately lower amount of taxes. Quite the opposite, there is concern if those poorer areas receive a proportionately lower amount of governmental services. See, e.g., Beal v. Lindsay, 468 F.2d 287 (2d Cir. 1972); Hawkins v. Town of Shaw, 437 F.2d 1286 (5th Cir. 1971). For a discussion of the municipal services cases, see Fessler \& Haar, Beyond the Wrong Side of the Tracks: Municipal Services in the Interstices of Procedure, 6 HARV. C.R.-C.L. L. Rev. 441 (1971).

195. See, e.g., Steel Hill Dev., Inc. v. Town of Sanbornton, 469 F.2d 956 (1st Cir. 1972)

196. See, e.g., Freilich, Development Timing, Moratoria, and Controlling Growth, 1974 INST. ON Planning, Zoning and Eminent Domain 147; Freilich and Ragsdale, Timing and Sequential Controls-The Essential Basis for Effective Regional Planning: An Analysis of the New Directions for Land 
and courts. ${ }^{197}$ Although many have argued that controls on growth are functionally indistinguishable from the regulations hitherto deemed exclusionary, ${ }^{198}$ the courts have seemed relatively receptive to a variety of restrictive measures packaged as growth management schemes. The approaches of the New York and California courts discussed in this Section are illustrative.

Suburban land use restrictions come in many forms. The classic targets of the open-up-the-suburbs groups have been such zoning practices as minimum lot size requirements, minimum floor space requirements, exclusion of uses deemed undesirable (mobile homes), and exclusion or restriction of multi-family dwellings. ${ }^{199}$ Provided that legislative purpose was the basis of analysis, these land use restrictions were most likely to fall if preservation of the character of the community could be discredited as a legitimate goal of zoning. Subdivision exactions were more troublesome because, while their effect might be exclusionary, their ostensible rationale appeared benign, or at least legitimate. Indeed, one of the most far-reaching aspects of the New Jersey cases was their invalidation of subdivision regulations deemed excessively costly or socioeconomically restrictive. ${ }^{200}$

The newer forms of restrictions are not aimed ostensibly at influencing the socioeconomic mix of a community. ${ }^{201}$ They are characterized by various development moratoria or charges on building permits, utility hook ups, and subdivision approvals. ${ }^{202}$ The moratoria may be absolute, in the sense that approval quotas are established, or couched in terms of performance standards-developers are permitted to proceed once the growth bottleneck identified is alleviated, either by public or private investment.

Professor Robert Ellickson, in his major work on suburban growth controls, identifies three types of costs on existing residents that can stem from new development and which, presumably, a local community might seek to

Use Control in the Minneapolis-St. Paul Region, 58 Minn. L. Rev. 1009 (1974); Deutsch, Land Use Growth Controls: A Case Siudy of San Jose and Livermore, California, 15 Santa Clara Law. 1 (1974); Note, Time Controls on Land Use: Prophylactic Law for Planners, 57 CoRnell L. Rev. 827 (1972). See also Marcus, Mandatory Development Rights Transfer and the Taking Clause: The Case of Manhattan's Tudor City Parks, 24 Buffalo L. Rev. 77 (1974).

197. E.g., Construction Ind. Ass'n v. City of Petaluma, 522 F.2d 897 (9th Cir. 1975), cert. denied, 424 U.S. 934 (1976); Associated Home Builders v. City of Livermore, 18 Cal.3d 582, 557 P.2d 473, 135 Cal. Rptr. 41 (1976); Golden v. Planning Bd. of Ramapo, 30 N.Y.2d 359, 285 N.E.2d 291, 334 N.Y.S.2d 138 (1972), appeal dismissed, 409 U.S. 1003 (1972).

198. See, e.g., Bosselman, Can the Town of Ramapo Pass a Law to Bind the Rights of the Whole World?, I Fla. ST. U. L. REv. 234 (1973).

199. See generally Bigham \& Bostick, supra note 28 , at 1120.

200. E.g., Southern Burlington County NAACP v. Township of Mount Laurel, 67 N.J. 151 , 183, 336 A.2d 713, 729 (1975), appeal dismissed, 414 U.S. 12 (1975) (holding that bedroom restrictions were clearly contrary to the general welfare).

201. Construction Ind. Ass'n v. City of Petaluma, 522 F.2d 897, 908 n.16 (9th Cir. 1975), cert. denied, 424 U.S. 934 (1976).

202. See Ellickson, supra note 9, at 390-92. 
recoup or forestall: nuisance costs, congestion costs, and fiscal costs. ${ }^{203}$ As Ellickson uses the term, nuisance costs "arise when a new housing project is subnormal in quality." 204 That is, any housing development that is below prevailing standards of quality imposes costs on existing residents if, for whatever reason, it causes nearby land to decrease in value. This is the classic description of an exclusionary purpose, and promotion of that end would likely be met with hostility as exclusionary. ${ }^{205}$ The Pennsylvania and New Jersey decisions discussed in the last Section certainly viewed the avoidance of that type of cost as an impermissible, exclusionary regulatory objective. ${ }^{206}$

Most of the recent suburban growth control activity-construction moratoria and quotas-seem aimed at preventing the congestion costs of growth. As Professor Ellickson correctly notes, much of the housing inhibited by growth control measures "would be superior in quality to most current housing in their neighborhoods," ${ }^{207}$ a point not lost on reviewing courts. ${ }^{208}$ However, all growth, even of the ostensibly high style variety, can contribute to such community-wide disamenities as diminished air and water quality, increased traffic congestion, and a variety of overcrowding (e.g., of schools or recreational facilities). ${ }^{209}$ Where courts have perceived land use restrictions as legitimately coping with such congestion costs, they have been more receptive to a community's police power claims of justifiable regulatory authority. ${ }^{210}$ Indeed, the perceived distinction between control of congestion and nuisance costs has played an important role, albeit implicitly, in altering the characterization of restrictive land use practices from the pejorative "exclusionary zoning" to the laudable "growth management.",211

\section{Id. at 441 .}

204. Id.

205. But see Village of Belle Terre v. Boraas, 416 U.S. 1 (1974) (holding that zoning to preserve the character of a community is a permissible object of the police power). Professor Ellickson would allow a municipality to forbid nuisance features unless the antinuisance restrictions were grossly inefficient. Ellickson, supra note 9 , at 441 .

206. Indeed, the first circuit, in reviewing a large lot zoning scheme, went to great lengths to distinguish the permissible environmental purpose in that case from the exclusionary purposes struck down in cases involving more highly developed suburban areas. Steel Hill Dev., Inc. v. Town of Sanbornton, 469 F.2d 956 (1st Cir. 1972).

207. Ellickson, supra note 9 , at 441 .

208. E.g., Construction Ind. Ass'n. v. City of Petaluma, 522 F.2d 897, 902 (9th Cir. 1975), cert. denied, 424 U.S. 934 (1976); Associated Home Builders, Inc. v. City of Livermore, 18 Cal.3d 582, 602, 557 P.2d 473, 484, 135 Cal. Rptr. 41, 52 (1976).

209. For further discussion of these issues, see Keyes, Channeling Metropolitan Growth, 43:2 LAw \& Contemp. Prob. Spring 1979, at 239.

210. E.g., Golden v. Planning Bd. of Ramapo, 30 N.Y.2d 359, 285 N.E.2d 291, 334 N.Y.S.2d 135 (1972), appeal dismissed, 409 U.S. 1003 (1972). Compare Belle Harbor Realty Corp. v. Kerr, 35 N.Y.2d 507, 323 N.E.2d 697, 364 N.Y.S.2d 160 (1974) with Westwood Forest Estates, Inc. v. Village of South Nyack, 23 N.Y.2d 424, 244 N.E.2d 700, 297 N.Y.S.2d 129 (1969). But see Board of Supervisors v. Horne, 216 Va. 113,215 S.E.2d 453 (1975) (holding invalid interim moratorium on the filing of applications for approval of site plans and preliminary subdivision plats).

211. Professor Ellickson takes a somewhat less favorable view of growth management motiva- 
The third cost associated with growth is fiscal: "They arise when the incremental costs to municipal taxpayers of servicing a new development exceed the incremental municipal revenues the development would engender." 212 Recoupment of the incremental costs of growth characterizes legislation that has been criticized as exclusionary and sustained as promoting orderly growth. Here, the disagreement among courts in considering legislation as either impermissibly exclusionary or acceptable growth management reflects a divergence of basic values. For example, the New Jersey court in Mt. Laurel saw costly development conditions and exactions to be exclusionary, presumably even if they reflected the true incremental costs of growth. Implicitly, then, courts that object to the imposition of the full cost of development on the new development are requiring a community to subsidize growth. ${ }^{213}$ Those that permit recovery of reasonable incremental costs of growth from developers are apparently willing to allow a balancing of the expanded opportunities of growth and the desirability of conserving resources. ${ }^{214}$

\section{A. New York}

The New York Court of Appeals confronted the growth management issue in the well known case of Golden $v$. Planning Board of Ramapo. ${ }^{215}$ Ramapo was a classic developing community in the Mt. Laurel sense; its population had increased dramatically and projections indicated continued increases. As part of its planning process, the town adopted two capital improvements programs that extended over an eighteen year period. These programs were intended to implement the land use design of the master plan.

In order to eliminate "premature subdivision and urban sprawl,"216 the town restricted residential development so that it would "proceed according to the provision of adequate municipal facilities and services."217 The technique for restraining growth was to require that residential development proceed only upon issuance of special permits, which would be granted when specified

\footnotetext{
tion, even when it is used to prevent congestion costs. Ellickson, supra note 9, at 442-43. He argues that suburban homeowners are likely to pursue "fiscal squeeze zoning," a term borrowed from economist Michelle White, see White, Fiscal Zoning in Fragmented Metropolitan Areas, in Fiscal. Zoning and Land Use Controls 31 (E. Mills \& W. Oates eds. 1975). Ellickson, supra note 9, at 451-52. Ellickson argues that " $t]$ he preeminent concern in cases of alleged fiscal discrimination should be to ensure horizontal equity among landowners." Id. at 453. He would oppose growth management strategies aimed at recouping increased congestion costs if those types of charges had not been imposed on oldtimers in the community. Charges solely on newcomers, according to Eltickson, are "instruments of housing monopolization efforts." Id. at 452.

212. Ellickson, supra note 9 , at 441 .

213. See notes $178,180 \& 194$ supra.

214. E.g., Associated Home Builders v. City of Walnut Creek, 4 Cal.3d 633, 484 P.2d 606, 94 Cal. Rptr. 630 (1971), appeal dismissed, 404 U.S. 878 (1971).

215. 30 N.Y.2d 359, 285 N.E.2d 291, 334 N.Y.S.2d 135 (1972), appeal dismissed, 409 U.S. 1003 (1972).

216. Id. at 367,285 N.E.2d at 295,334 N.Y.S.2d at 143.

217. Id.
} 
performance standards were satisfied. These standards were based on the availability of designated essential facilities or services, such as sewers, parks, schools, and roads. ${ }^{218} \mathrm{~A}$ development point system was established to determine when a residential development permit would issue. ${ }^{219}$ The rationale of the plan was to coordinate residential growth with the town's orderly plan for providing facilities and services. ${ }^{20}$ Developers were permitted (on their own initiative) to accumulate development points by providing facilities or services on their own. In that way, landowners were not locked into the timetable specified for their parcels in the township's capital improvements program; if justified by economic circumstances, they could advance the date of development by appropriate private investment. ${ }^{21}$

The groundwork for the Ramapo plan was extraordinarily well laid. The town had developed a master plan with funds granted for this purpose by the federal government. The process of developing the master plan included a four volume study of existing land uses, community resources and projected needs. The study proposals were incorporated into the plan, which was adopted and implemented by a comprehensive zoning ordinance and a capital improvements program. The sequential growth scheme of special use permits for residential development was added later as an amendment to the overall zoning ordinance. ${ }^{222}$

It was clear from the opinion that the New York court was impressed by the town's planning efforts. Judge Scileppi noted that the town's existing facilities were "inadequate to service increasing demands," 223 and assumed that the capital improvements program was a legitimate attempt to manage growth, not a "veiled" attempt at "exclusion." $224 \mathrm{He}$ found the sequential development policy to be an "undisputably laudatory" purpose, ${ }^{25}$ and charac-

218. Id. at 368,285 N.E.2d at 295,334 N.Y.S.2d at $143-44$.

219. Id. at 368,285 N.E. $2 \mathrm{~d}$ at 295,334 N.Y.S.2d at 144. A proposed residential development had to accumulate fifteen development points before a special permit would issue. Points were awarded according to the value assigned to particular improvements. The five essential facilities or services were sewers, drainage facilities, parks or recreation areas (including schools), roads, and firehouses. The Town Board could vary the development point requirements if a modification or variance would be consistent with the development plan. In addition, other provisions of the system alleviated potentially unreasonable restrictions. $I d$.

220. Id. See generally, Freilich, Interim Development Controls: Essential Tools for Implementing Flexible Planning and Zoning, 49 J. URB. L. 65 (1971).

221. 30 N.Y.2d at $368-69,285$ N.E.2d at 296,334 N.Y.S.2d at 144. The Ramapo plan also provided for a reduction of the assessed value of land for purposes of property taxation during the period of restriction. Id at 369,285 N.E.2d at 296,334 N.Y.S.2d at 144.

222. Id. at $366-67,285$ N.E.2d at $294-95,334$ N.Y.S.2d at $142-43$.

223. Id. at 366 n.1, 285 N.E.2d at 294 n.l, 334 N.Y.S.2d at 142 n.l.

224. Id. (paraphrasing National Land and Inv. Co. v. Kohn, 419 Pa. 504, 215 A.2d 597 (1965)). For a discussion of the effect of a village's refusal to construct an adequate sewage system while requiring new housing units to be hooked up to the system, see Charles v. Diamond, 41 N.Y.2d 318, 360 N.E.2d 1295, 392 N.Y.S.2d 594 (1977).

225. 30 N.Y.2d at 369,285 N.E.2d at 296,334 N.Y.S.2d at 144. 
terized the growth plan as "the product of foresighted planning calculated to promote the welfare of the township." 226

Despite its favorable disposition to the growth management approach adopted by Ramapo, the New York court was not unaware of the socioeconomic issues involved when local governments impose restrictive land use controls. Judge Scileppi acknowledged the criticism of "community autonomy in land use controls because of its pronounced insularism and its correlative role in . . . crippling efforts toward regional and State-wide problem solving."227 Citing the Pennsylvania exclusionary zoning cases, he recognized the interests of potential residents in the land use activities of a suburban community. ${ }^{228}$ But he felt justified in according local governments the "usual presumption of validity" 229 in zoning matters because "the power to zone under current law is vested in local municipalities," and he felt "constrained" to accept that legislative allocation of authority ${ }^{\mathbf{2 3 0}}$ since "matters of land use and development are peculiarly within the expertise of students of city and suburban planning, and thus well within the legislative prerogative."231 For Judge Scileppi the propriety of judicial self-restraint in the planning field made unpalatable the alternative of invalidating a local growth plan, in effect holding such local initiatives hostage "in the wistful hope" that a regional legislative planning structure would emerge. ${ }^{232}$

In approving the Ramapo scheme, the New York court in dictum made it clear that it would not countenance "community efforts at . . . exclusion."233 Moreover, citing the Euclid dictum, ${ }^{234}$ the court indicated that it would consider the impact of land use restrictions on the "general public interest" ${ }^{235}$ as well as on the community's own general welfare. It recognized that, quite apart from the benign purpose of a locality in adopting a growth plan, the court should view as "inherently suspect" ${ }^{236}$ a land use scheme that has the effect of restricting in-migration. Although the distinction the court was drawing was imprecise, what seemed important was that Ramapo's capital improvements program suggested an accommodation to, not an avoidance of, future growth. ${ }^{237}$ It was a temporary, albeit lengthy, limitation that was reasonable

226. Id. at 380,285 N.E.2d at 303,334 N.Y.S.2d at 153.

227. Id. at 374,285 N.E.2d at 299,334 N.Y.S.2d at 149.

228. Id. at 375,285 N.E.2d at 300,334 N.Y.S.2d at 149.

229. Id. at 377,285 N.E.2d at 301,334 N.Y.S.2d at 151.

230. Id. at 375,285 N.E.2d at 300,334 N.Y.S.2d at 149.

231. Id. at $376-77,285$ N.E.2d at 301,334 N.Y.S.2d at 151.

232. Id. at 376,285 N.E.2d at 300,334 N.Y.S.2d at 150 .

233. Id. at 378, 285 N.E.2d at 302, 334 N.Y.S.2d at 152.

234. Village of Euclid v. Ambler Realty Co., 272 U.S. 365, 390 (1926).

235. 30 N.Y.2d at 378,285 N.E.2d at 302,334 N.Y.S.2d at 152.

236. Id. at 375,285 N.E.2d at 300, 334 N.Y.S.2d at 149.

237. This had also been a major concern of the Pennsylvania court in National Land and Inv. Co. v. Kohn, 419 Pa. 504, 528, 215 A.2d 597, 610 (1965) ("Zoning is a means by which a govern- 
given the resources available to the community and the built-in flexibility of the zoning scheme.

The court's validation of the Ramapo scheme reflected its endorsement of the goals $\mathrm{c}$ : planning; ${ }^{238}$ the Ramapo plan was designed to substitute governmental planning decisions for those of developers as guides for future development. ${ }^{239}$ Rather than adopting a responsive role for public sector investment, the Ramapo planners determined in advance the location of and schedule for public investment, thereby assuming a proactive rather than a reactive role in channeling development. ${ }^{240}$ Moreover, the town accepted the responsibility of a generalized obligation to accommodate residential development, but it did not define this duty in terms of a specific commitment to particular landowners to accommodate their desire to develop their property. By accepting the Ramapo approach, the New York court allowed communities to define whatever affirmative obligations they might have in general terms. Reasonable capital improvement allocations are all right, even if particular landowners suffer economic hardship for relatively long periods of time. ${ }^{241}$

Subsequent to its Ramapo decision, the New York court had an opportunity to amplify its reasoning with respect to the more traditional exclusionary zoning claim. In Berenson v. Town of New Castle ${ }^{242}$ the court dealt with a developing community that barred multifamily dwellings and set aside most of its land for one and two acre single-family residences. ${ }^{243}$ Judge Jasen emphasized that the Ramapo court had warned that it would not tolerate exclusionary measures. The Berenson court reached out to develop that Ramapo dictum into doctrine. ${ }^{244}$

mental body can plan for the future-it may not be used as a means to deny the future.") See Charles v. Diamond, 41 N.Y.2d 318, 360 N.E.2d 1295, 392 N.Y.2d 594 (1977)

238. The New York Court of Appeals was distinctly less receptive to an amendment to a zoning ordinance which barred new construction of multiple dwellings throughout a village when the purpose of the enactment was to "alleviate the burden on the village's sewage disposal plant, and not because of any requirement of or change in the comprehensive plan for the development of the village." Westwood Forest Estates, Inc. v. Village of South Nyack, 23 N.Y.2d 424, 426, 244 N.E.2d 700, 701, 297 N.Y.S.2d 129, 131 (1969). See Charles v. Diamond, 41 N.Y.2d 318, 360 N.E.2d 1295. 392 N.Y.S.2d 594 (1977). The coordination between planning and zoning in Ramapo seems to have been of extreme importance to the court.

239. Some commentators have expressed skepticism about the role of planning in channeling urban development. See sources cited in note 17 supra. See also Tarlock. Toward a Revised Theory of Rezoning, 1972 Land USE CONT. Ans. 141, reprinted in 1 URban Land INSTITUTE, Management and Control of Growth 228 (R. Scott ed. 1975).

240. For discussion of capital improvements as a technique for channeling growth, see Deutsch, Capital Improvement Controls as Land Use Devices, 9 Envt'L L. 61 (1978); Hirst \& Hirst, Capital Facilities Planning as a Growth Tool, in 2 Urban Land Institute, Management and ConTROL OF GROWTH 461 (R. Scott ed. 1975).

241. See generally Note, Phased Zoning: Regulation of the Tempo and Sequence of Land Development, 26 Stan. L. REv. 585 (1974).

242. 38 N.Y.2d 102, 341 N.E.2d 236, 378 N.Y.S.2d 672 (1975).

243. Id. at 105,341 N.E.2d at 239,378 N.Y.S.2d at 676 .

244. In Berenson the lower courts had denied summary judgment. On appeal, the court of 
Implicitly eschewing the New Jersey approach in Mt. Laurel, the New York court stressed the legislative nature of zoning and the "anomalous" role of a court that would be "required to perform the tasks of a regional planner." 245 As the New York majority did in Ramapo and the New Jersey majority did in Oakwood at Madison, the Berenson court urged the legislature to establish a mechanism for regional planning. ${ }^{246}$ Simultaneously, the Berenson court reiterated its Ramapo findings-that the development decision cannot rest exclusively in the control of one local community.

The Berenson doctrine included regional factors in the process of judicial review but was more modest in scope than the New Jersey and Pennsylvania approaches. With regard to its regulation of land use, a community must provide a "properly balanced and well ordered plan for the community" that adequately fulfills present and future needs of existing residents. ${ }^{247}$ In addition, a community must give consideration to regional needs, balancing its own interests with those of the region. ${ }^{248}$ A reviewing court must "assess the reasonableness of what the locality had done, ${ }^{249}$ considering the external "effect of the zoning ordinance on the neighboring communities."250 In contrast to the Mt. Laurel approach, however, the court stated carefully that there is no requirement for a community to make room for a use if an appraisal of regional needs indicates that they are being satisfied otherwise. ${ }^{251}$ The notion of community diversity was thus seen as an important value, provided regional needs were being met satisfactorily.

The New York court's approach in Berenson reflects its sensitivity to the regional issues of suburban land use control cases. In Ramapo that court had acknowledged regional concerns but concluded that Ramapo's phased growth strategy was a reasonable accommodation of local and regional interests. In Berenson the court remanded for trial to develop evidence on the issue of reasonableness. By imposing a regional standard without articulating a substantive rule such as "fair share," the New York court entered the suburban growth control arena more circumspectly than did the New Jersey or Pennsylvania courts. In essence, the court required local communities to consider regional as well as local welfare concerns in generating their zoning

appeals agreed that factual issues remained to be resolved at the trial level. Instead of routinely remanding for trial, the court moved to clarify the Ramapo dictum: "In view of the highly significant public policy considerations involved, it is necessary that we set forth our views at some length in order that, upon the trial to be had in this case, the proper factual issues will be considered." Id. at 107,341 N.E.2d at $239-40,378$ N.Y.S.2d at 677.

245. Id. at 111,341 N.E.2d at 243,378 N.Y.S.2d at 682 .

246. Id.

247. Id. at 110,341 N.E.2d at 242,378 N.Y.S.2d at 680 .

248. Id. at 110,341 N.E.2d at 242,378 N.Y.S.2d at 681

249. Id. at 110,341 N.E.2d at 243,378 N.Y.S.2d at 681 .

250. Id. at $111,34 \mathrm{l}$ N.E. $2 \mathrm{~d}$ at 242,378 N.Y.S.2d at 681

251. Id. at 111,341 N.E.2d at 243,378 N.Y.S.2d at 681 . 
schemes. The reasonableness standard gives the locality considerable flexibility, but the court will oversee the process of planning - that regional data are developed, projections on regional needs made, etc. It sees the locality as exercising some form of fiduciary responsibility towards its region. This type of review puts the initial responsibility on communities to determine a fair balancing of local and regional needs and allows the court to avoid entanglement in the nitty gritty of planning that has surfaced in New Jersey.

\section{B. California}

Like New York, California has confronted cases involving growth management and claims of socioeconomic exclusion. Like New York's courts, the courts in California have been sympathetic to the growth limiting actions of suburban communities, typically declining to characterize restrictive land use practices as impermissibly exclusionary. Also like New York's courts, the California courts have recognized the risk of excessive insularity if the local community is permitted to consider only its own general welfare in exercising the zoning function.

The California Supreme Court has held valid a variety of building moratoria linked to specified performance standards, the type of local activity endorsed in Ramapo. For example, in Builders Association v. Superior Court ${ }^{252}$ the court sustained an initiative by the voters of the city of San Jose that restricted rezoning land in certain areas for residential use for two years, pending further study of the impact of residential development. ${ }^{253}$ The San Jose initiative identified certain "impacted" areas of the community based on school enrollments. The goal was to stop further housing construction in areas where school conditions did not meet performance standards established in the ordinance.

During the two year moratorium, a study was to be commissioned to consider all issues linked to additional residential development. A landowner with property in an impacted area could be exempted from the moratorium by agreeing "to provide a satisfactory alternative to permanent school construction."254 Thus, as in Ramapo, a developer could speed up the development process by privately meeting the criteria specified in the performance standards.

In rejecting the challenge to the ordinance, the California court saw "no reason why the city may not condition approval of the zoning application

252. 13 Cal.3d 225, 529 P.2d 582, 118 Cal. Rptr. 158 (1974), appeal dismissed, 427 U.S. 901 (1976).

253. Id. at 228, 529 P.2d at 583, 118 Cal. Rptr. at 159. For a discussion of the San Jose initiative, see Deutsch, supra note 196.

254. $13 \mathrm{Cal} .3 \mathrm{~d}$ at 228,529 P.2d at 583-84, $118 \mathrm{Cal}$. Rptr. at 159-60. Absence of the private in vestment alternative is troublesome even for courts that approve moratoria. See Charles v. Diamond, 41 N.Y.2d 318, 360 N.E.2d 1295, 392 N.Y.S.2d 594 (1977) 
upon certification . . that adequate [school] facilities can be provided."255 Implicitly, the court indicated that concern with school overcrowding is a legitimate rationale for zoning, and the condition on rezoning was a reasonable way of coping with the concern.

The court was willing to accept the view that fiscal costs and congestion costs imposed by new development could properly be exacted from developers by local, growing communities. ${ }^{256}$ Justice Tobriner, for the majority, cited (approvingly) an earlier subdivision exaction case for the proposition that a community can require the dedication of land or a payment of a fee in lieu of dedication "if the need for increased facilities was attributable to the developer's activities." 257

Unlike the New Jersey approach, the California cases do not seem to determine the reasonableness of the cost imposed on the developer in an absolute sense, but examine the reasonableness of the amount imposed in light of the costs the municipality would likely incur as a result of the development. In a broad decision that upheld a park land dedication exaction as part of a subdivision control provision, the court recognized that subdividers may tack on to the cost of housing the dedication charges, passing along higher costs to the consumers in the form of higher prices. ${ }^{258}$ It acknowleged that a community might attempt to "prevent the influx of economically depressed persons" 259 by setting a charge "unreasonably high," but in contrast to the New Jersey court's approach, the California court's concept of reasonableness appears to be related to the notion of marginal cost from new development -i.e., whether the exaction is fairly traceable to costs imposed by new development, both in cause and amount. The Walnut Creek court was aware that high subdivision exactions could deter construction of low-cost housing, but it concluded that "these considerations must be balanced against the phenomenon of the appallingly rapid disappearance of open areas in and around our

255. 13 Cal.3d at 232, 529 P.2d at 587. 118 Cal. Rptr. at 163. Whether subdivision approvals can be linked to off-site conditions not intrinsic to the development itself has been questioned in other contexts. See. e.g., Garipay v. Town of Hanover, 116 N.H. 34, 351 A.2d 64 (1976) (upholding denial of proposed subdivision on ground of inadequacy of main network of town roads to handle increased traffic caused by the subdivision). But see Belle Harbor Realty Corp. v. Kerr, 35 N.Y.2d 507, 323 N.E.2d 697, 364 N.Y.S.2d 160 (1974) (holding that an antiquated sewage system did not justify revocation of building permits unless revocation was calculated to alleviate or prevent a crisis condition dangerous to public health and municipality was presently rectifying problem).

256. 13 Cal.3d at 232 n.6, 529 P.2d at 587 n.6, 119 Cal. Rptr, at 163 n.6.

257. Id. The Court cited Associated Home Builders v. City of Walnut Creek, 4 Cal.3d 633, 484 P.2d 606, 94 Cal. Rptr. 630 (1971), appeal dismissed. 404 U.S. 878 (1971), and in turn noted that case's reliance on Jordan v. Village of Menomonee Falls, 28 Wis.2d 608, 137 N.W.2d 442 (1966), appeal dismissed, 385 U.S. 4 (1966).

258. Associated Home Builders v. City of Walnut Creek, 4 Cal.3d 633, 648, 484 P.2d 606, 618, 94 Cal. Rptr. 630, 642 (1971), appeal dismissed, 404 U.S. 878 (1971).

259. Id. at 642,484 P.2d at 618,94 Cal. Rptr. at 638. 
cities." 260 Consequently, in the subdivision area ${ }^{261}$ and, subsequently, in the San Jose growth moratorium context, ${ }^{262}$ the California court was prepared to accept the proposition that new growth need not be subsidized, but can be compelled by developing communities to pay for the costs associated with development.

The willingness of the California Supreme Court to permit local units of government to manage growth by imposing significant development exactions and requiring that substantial performance standards be met is paralleled by that court's awareness of the competing values involved. As the New York Court of Appeals did in Ramapo, the California court has recognized the potential for excessive burdens a community can impose on those not living within its political boundary at any given time but who consider the community part of their relevant housing market.

As the New York court did in Berenson, the California court in Associated Home Builders $v$. City of Livermore ${ }^{263}$ held that if a land use restriction has an effect beyond the boundaries of the enacting municipality, its constitutionality depends not only on its effect on the enacting community "but upon the welfare of the surrounding region" as well. ${ }^{264}$ The court declined to adopt a rigorous standard of review, reaffirming "the established constitutional principle that a local land use ordinance falls within the authority of the police power if it is reasonably related to the public welfare." 265 It extended the scope of the relevant constituency whose welfare must be considered to include "the interests of nonresidents who are not represented in the city legislative body and cannot vote on a city initiative." 266

A reviewing court in California, under Livermore, is constrained to examine regional interests, but there is no substantive duty imposed on municipalities other than being reasonable in their treatment of regional interests, since the "proper constitutional test is one which inquires whether the ordinance reasonably relates to the welfare of those whom it significantly affects." 267 The court was well aware of the "deep social antagonisms" involved in the "conflict between the environmental protectionists and the egalitarian humanists."268 The competing interests reflect a "collision between the forces that would save the benefits of nature and those that would preserve the opportunity of peo-

260. Id.

261. See id.

262. Builders Ass'n v. Superior Court, 13 Cal.3d 225, 529 P.2d 582, 118 Cal. Rptr. 158

(1974), appeal dismissed, 427 U.S. 901 (1976).

263. 18 Cal.3d 582, 557 P.2d 473, 135 Cal. Rptr. 41 (1976).

264. Id. at 601,557 P.2d at 483,135 Cal. Rptr. at 51 .

265. Id. at 607,557 P.2d at 487, $135 \mathrm{Cal}$. Rptr. at 55 .

266. Id.

267. Id.

268. Id. at 608,557 P.2d at 488,135 Cal. Rptr. at 56 . 
ple in general to settle." ${ }^{269}$ Provided that the municipality's ordinance "represents a reasonable accommodation of the competing interests" between those asserting a "vital interest in limiting immigration" and those "[o]utsiders searching for a place to live in the face of a growing shortage of adequate housing," 270 the court will sustain it.

In articulating its reasonableness standard, the court in Livermore noted explicitly the continued propriety of judicial deference to legislative land use judgments, ${ }^{271}$ an approach consistent with that announced in Euclid, ${ }^{272}$ but inconsistent with the strict scrutiny approach of the New Jersey ${ }^{273}$ and Pennsylvania courts. ${ }^{274}$ Nevertheless, in light of the political nonrepresentation of regional interests in a suburban community's legislative process, ${ }^{275}$ the court noted that the reasonableness criterion would not be toothless: "There must be a reasonable basis in fact, not fancy, to support the legislative determination." ${ }^{\mathbf{2 7 6}}$ This statement suggests that the court will not dream up rationales to support a community's actions, ${ }^{277}$ but, while the court indicated that "judicial deference is not judicial abdication," 278 it stated that the party challenging the validity of the ordinance has the burden of presenting the evidence and documentation needed by the reviewing court if the general presumption of validity is to be overcome. ${ }^{279}$

In Ramapo the New York court emphasized the temporary nature of the development restriction, the town's plans for an orderly capital improvements program, and the ability of developers to obtain development points by private construction of specified facilities. ${ }^{280}$ The California decision in the San Jose case reflected many of these same considerations. ${ }^{281}$ The Livermore ordinance, however, was more far-reaching than either the Ramapo or San Jose scheme since it did not commit the city to a construction program, had no time delimitation, and allowed no private construction alternative. Rather, the

269. Id.

270. Id. at $609,557 \mathrm{P} .2 \mathrm{~d}$ at $488,135 \mathrm{Cal}$. Rptr. at 56.

271. Id. at 609, 557 P.2d at 489,135 Cal. Rptr. at 57.

272. 272 U.S. at 388 ("If the validity of the legislative classification for zoning purposes be fairly debatable, the legislative judgment must be allowed to control.")

273. See Section III.B. supra.

274. See Section III.A. supra.

275. This factor persuades Professor Ellickson that an activist state court review is appropriate. See Ellickson, supra note 9, at 463-75.

276. $18 \mathrm{Cal} .3 \mathrm{~d}$ at 609,557 P.2d at $489,135 \mathrm{Cal}$. Rptr. at 57.

277. For a discussion of state court activism in the economic substantive due process area, see

Note, State Economic Substantive Due Process: A Proposed Approach, 88 Y Ale L. J. 1487 (1979).

278. $18 \mathrm{Cal} .3 \mathrm{~d}$ at 609,557 P.2d at $489,135 \mathrm{Cal}$. Rptr. at 57.

279. Id.

280. 30 N.Y.2d at $366-67,368,379,285$ N.E.2d at $294-95,296,302,334$ N.Y.S.2d at 142-43, $144,153$.

281. See Builders Ass'n v. Superior Court, 13 Cal.3d 225, 233, 529 P.2d 582, 587, 118 Cal.

Rptr. 158, 163 (1974), appeal dismissed, 427 U.S. 901 (1976). 
ordinance barred the issuance of additional residential construction permits until educational, sewage and water supply standards were satisfied.

The California Supreme Court did not rule the ordinance constitutional but remanded for development of evidence on reasonableness. ${ }^{282}$ In the review process, the trial court need only "forecast the probable effect and duration of the restriction," by ascertaining "the extent to which public facilities currently fall short of the specified standards, . . . whether the city or appropriate regional agencies have undertaken to construct needed improvements," and "when the improvements are likely to be completed." ${ }^{283}$ Although considerable ambiguity remains on this point, the California rule may be more permissive to developing municipalities than the doctrine of Ramapo, in which the New York court stressed the saving features and the community's commitment to proceeding with capital improvements. Certainly, Livermore did not suggest, as Ramapo had, that lack of a legislatively adopted plan for coping with growth by meeting the established performance standards might result in a holding adverse to the community. ${ }^{284}$ The extent to which California will impose a judicially defined duty on suburban communities to invest in public improvements to accommodate growth must await subsequent decisions.

\section{Federal Court Treatment of Challenges to Restrictive Land Use Practices}

In differing degrees, the courts of Pennsylvania, ${ }^{285}$ New Jersey, ${ }^{286}$ New York $^{287}$ and California ${ }^{288}$ have recognized the significance of regional factors in determining the validity of suburban land use controls. In that sense they have developed the dictum in Euclid about regional concerns ${ }^{289}$ into substantive doctrine-elaborate and complex in the case of Pennsylvania and New

282. The court required that the ordinance be reasonably related to the public welfare. Since zoning ordinances have a presumption of constitutionality, they "come before the court with every intendment in their favor." 18 Cal.3d at 605,557 P.2d at 486.135 Cal. Rptr. at 54 . Some other states, notably Virginia, have imposed a more stringent review under the reasonableness criterion. See, e.g., Matthews v. Board of Zoning Appeals, 218 Va. 720, 237 S.E.2d 128 (1977). See also Board of Supervisors v. Horne, 216 Va. 113, 215 S.E.2d 453 (1975). The New York courts have intimated that they might take a tougher stance in the absence of a private investment alternative and in the absence of a rational growth management plan. See Charles v. Diamond, 41 N.Y.2d 318, 360 N.E.2d 1295,392 N.Y.S.2d 594 (1977)

283. 18 Cal.3d at 608,557 P. $2 \mathrm{~d}$ at 488,135 Cal. Rptr. at 56.

284. The suggestion in Ramapo was discussed at greater length in Charles v. Diamond, 41 N.Y.2d 318,360 N.E.2d 1295, 392 N.Y.S.2d 594 (1977).

285. See Section III.A. supra.

286. See Section III.B. supra.

287. See Section IV.A. supra.

288. See Section IV.B. supra.

289. See Village of Euclid v. Ambler Realty Co., 272 U.S. 365, 390 (1926). 
Jersey, ${ }^{290}$ more tentative and skeletal in New York and California. In part, the differences in approach reflect the varying perceptions of suburban land use controls as either exclusionary-a pejorative label and a practice to be condemned ${ }^{291}$ - or oriented toward an orderly management of growth and development-a commendable goal to be looked on with favor. ${ }^{292}$

For state courts sensitive to the exclusionary effect of suburban land use restrictions, recognition of the regional nature of the problem has been coupled with a growing hostility to zoning purposes considered exclusionary. Consequently, the Pennsylvania and New Jersey courts have been relatively unreceptive to suburban claims that "fiscal" or "preservation-of-the-characterof-the-community" objectives justify exclusionary land use practices. The willingness of these state courts to narrow the range of legitimate or overriding local zoning objectives has been an important component of their assault on exclusionary zoning. ${ }^{293}$

Quite apart from the focus on regionalism and disfavored purposes, the state courts have also developed a rich body of case law that derives from the Nectow decision. ${ }^{294}$ These cases focus on the harm or injustice done to individual landowners by the application of a particular land use regulation. The Pennsylvania and New York courts have been particularly solicitous of landowner interests in protecting against perceived governmental overreaching. ${ }^{295}$

290. For consideration of the problem of complex remedies in cases of exclusionary zoning. see Ellickson, supra note 9, at 490-93; Developments in the Law-Zoning, 91 HARv. L. REv. 1427, 1700-07 (1978) [hereinafter cited as Zoning Development]; Note, The Inadequacy of Judicial Remedies in Cases of Exclusionary Zoning, supra note 137, at 766-86.

291. Professor Sager, for instance, has described exclusionary zoning as a "deplorable circumstance." Sager, Insular Majorities Unabated: Warth v. Seldin and City of East Lake v. Forest City Enterprises, 9I HaRv. L. REv. 1373, 1420 (1978). Ostensible federal court acquiesence in these practices is dismissed sarcastically: "[M]ean and self-serving acts of exclusion are apparently to be received as jeweled exercises of the police power." Id. at 1421. See also Hogue, Eastlake and Arlington Heights: New Hurdles in Regulatory Urban Land Use?, 28 CASE W. L. Rev. 41 (1977); Sager, supra note 28 , at 791 ("What is at issue is a governmental act that strongly reinforces the social propensity to form tight little islands of residential exclusivity."); Zoning Development, supra note 290 , at $1625-32$.

292. See, e.g., Golden v. Planning Bd. of Ramapo, 30 N.Y.2d 359, 285 N.E.2d 29l, 334 N.Y.S.2d 138 (1972), appeal dismissed, 409 U.S. 1003 (1972); Freilich, supra note 196.

293. See Mandelker, Racial Discrimination and Exclusionary Zoning: A Perspective on Arlington Heights, 55 TEx. L. REv. 1217, 1227 (1977) ("The principles used by the state courts to review the constitutionality of zoning amendments are substantive, not process-oriented; the courts examine the substantive reasons for granting a zoning amendment, not the process by which an amendment was granted.")

294. See text accompanying notes 8 \& 9 supra.

295. See Fred F. French Investing Co. v. City of New York, 39 N.Y.2d 587, 591, 350 N.E.2d $381,383,385$ N.Y.S.2d 5, 7 (1976), appeal dismissed, 429 U.S. 990 (1976) ("The State may not, under the guise of regulation by zoning, deprive the owner of the reasonable income productive or other private use of his property and thus destroy all but a bare residue of its economic value."); Lutheran Church in America v. City of New York, 35 N.Y.2d 121, 316 N.E.2d 305, 359 N.Y.S.2d 7 (1974); A ppeal of Kit-Mar Builders, Inc., 439 Pa. 466, 268 A.2d 765 (1970); National Land and Inv. Co. v. Easttown Twp. Bd. of Adjustment, $419 \mathrm{~Pa} .504,522,215$ A.2d 597, 607 (1965) 
Despite the articulated deference to local legislative judgments, state courts have in fact accepted a more aggressive role in reviewing suburban land use decisions than would be expected by examination of the broad body of recent federal economic substantive due process cases. ${ }^{296}$ This type of interventionism has received support ${ }^{297}$ even from those who advocate restraint with respect to federal judicial intervention. ${ }^{298}$

In this Section federal court developments in the land use control context will be examined and contrasted with the state court developments analyzed in the two Sections above. The discussion will examine initially the Supreme Court's treatment of challenges to local zoning purposes, noting how only race has been deemed an unacceptable local legislative objective. ${ }^{299} \mathrm{Next}$, the analysis will turn to cases in which litigants have urged that the interests of broader constituencies be considered in adjudicating the validity of local zoning measures. The Supreme Court has steadfastly declined to develop its regionalism dictum in Euclid into substantive constitutional doctrine. In Subsection $C$. the restrained federal judicial role in land use adjudication will be discussed and contrasted with the rather interventionist approaches of the state courts that have struck out at exclusionary land use practices. In this regard, the analysis will cover the federal role in fashioning remedies, in allowing access to sue, and in reviewing the zoning procedures. Subsection D. will consider the permissible scope of government regulation of individual landowners' freedom to use their property, as elaborated by the Supreme Court.

\section{A. Proper Zoning Purposes}

The Supreme Court has not been receptive to challenges of local governmental action based on alleged failure to pursue a valid police power objective. Whereas state courts articulated the public purpose doctrine as a limita-

\footnotetext{
(“[Z]oning involves governmental restrictions upon a landowner's constitutionally guaranteed right to use his property, unfettered, except in very specific instances, by governmental restrictions") (footnotes omitted).

296. For an indication of the rubber-stamp nature of federal constitutional review under economic substantive due process, see North Dakota Bd. of Pharmacy v. Snyder's Drug Stores, Inc., 414 U.S. 156 (1973); Ferguson v. Skrupa, 372 U.S. 726, 730 (1963) ("We have returned to the original constitutional proposition that courts do not substitute their social and economic beliefs for the judgment of legislative bodies, who are elected to pass laws. ") For comparable cases under equal protection, see City of New Orleans v. Dukes, 427 U.S. 297 (1976); Hughes v. Alexandria Scrap Corp., 426 U.S. 794, 812 (1976); Lehnhausen v. Lake Shore Auto Parts Co., 410 U.S. 356 (1973).

297. See Sager, supra note 291, at 1400-02; Zoning Development, supra note 290, at 1707-08.

298. E.g. Ellickson, supra note 9, at 469-75.

299. See generally Hogue, supra note 291, at 66-81; Mandelker, supra note 293, at 1236-49; Wright, Constitutional Rights and Land Use Planning: The New Era and the Old Reality, 1977 DuKE L.J. 841, 86l-65.
} 
tion on state police power activity, ${ }^{300}$ the Supreme Court has declined to interfere with what it deemed a legislative function.

The decision upholding the validity of the urban renewal program ${ }^{301}$ set the tone. Justice Douglas, writing for the Court, made it abundantly clear that no federal counterpart to the state-derived public purpose doctrine existed. Once the legislative body chose a policy goal and an implementing strategy, that was conclusive unless some constitutionally protected interest were impaired by the governmental action. ${ }^{302}$ Berman, therefore, established that the federal constitution's protection against governmental infringement of individual rights (for example, the requirement that it pay just compensation when it condemns land ${ }^{303}$ ) would be the only source of redress for aggrieved landowners. Restrictions on the source of federal power through a vibrant public purpose doctrine or by putting teeth into the Fifth Amendment's 'public use" limitation on the eminent domain power $^{304}$ of government were eschewed.

In Village of Belle Terre $v$. Boraas ${ }^{305}$ the Court held valid a local zoning ordinance that restricted land use to single-family dwellings and defined "family" to include a maximum of two unrelated persons constituting a single housekeeping unit. ${ }^{306}$ Belle Terre had about 700 residents and 250 homes. ${ }^{307}$ Lo-

300. E.g., Allydonn Realty Corp. v. Holyoke Hous. Auth., 304 Mass. 288, 23 N.E.2d 665 (1939); Mitchell v. North Carolina Indus. Dev. Fin'g Auth., 273 N.C. 137, 159 S.E.2d 745 (1968). See 6 E. McQulllin, supra note 2, at $\S 24.09$; note 2 supra. See generally, Note Some Legal and Economic Aspects of Indusirial Development Financing, 22 VAND. L. REv. 159, 174-80 (1968).

301. Berman v. Parker, 348 U.S. 26 (1954)

302. Id. at 32 .

303. U.S. Const, amend. V. See notes 550-51 infra.

304. In Berman the Court identified a proper public purpose with the "public use" concept expressed in the Constitution. In essence, the Court held that condemnation was merely a means of achieving a permissible governmental goal. Once the legislature determined that there was a proper public purpose, something about which the federal court would not intervene, the landowner's interest was protected merely by payment of just compensation. Berman, therefore, seemed to eliminate public use as a restriction on governmental eminent domain power. 348 U.S. at 33 .

Although it is often difficult to determine what uses are properly public within the terms of the fifth amendment, it is not self-evident that the public purpose and public use concepts should be found to be identical. Thus, our law typically allows a landowner to refuse to sell his land for entirely subjective reasons. This has been labeled a protection of that entitlement by a property rule. See Calabresi \& Melamed, Property Rules, Liability Rules and Inalienability: One View of the Cathedral, 85 HARv. L. REv. 1089, 1092 (1972). The fifth amendment permits government to use its power of eminent domain by the payment of just compensation. That authority transforms the form of legal protection of a private entitlement from a property rule to a liability rule. Damages are then paid according to the objective market value of the land at its highest and best use. Autonomous subjective valuation is ignored. It is arguable that the fifth amendment's public use restriction should be treated as an independent limitation on governmental power, since the use of eminent domain is different from typical coercive exercises of police power in that it transforms the form of legal protection accorded to private entitlements from property rule protection to liability rule protection. See generally Calabresi \& Melamed, supra.

305. 416 U.S. 1 (1974).

306. Id. at 2 . 
cated near the Stony Brook campus of the State University of New York, Belle Terre's land area comprised less than one square mile; the zoning ordinance was apparently designed to exclude boarding houses and fraternity houses populated by student groups. ${ }^{308}$

The Boraas plaintiffs alleged that the zoning ordinance "expresse[d] the social preferences of the residents for groups that will be congenial to them; that social homogeneity is not a legitimate interest of government . . ."309 The Court concluded that the zoning provision affected no fundamental interest protected by the federal constitution and did not classify on a suspect basis such as race. Therefore, Justice Douglas found that only "economic and social legislation" 310 was involved, and consequently the standard for reviewing that legislative classification was the extremely deferential rationality criterion. Recognizing that multiple occupancy in "boarding houses, fraternity houses, and the like" ${ }^{11}$ can increase congestion and noise, the Court noted:

A quiet place where yards are wide, people few, and motor vehicles restricted are legitimate guidelines in a land-use project addressed to family needs. This goal is a permissible one within Berman v. Parker .... The police power is not confined to elimination of filth, stench, and unhealthy places. It is ample to lay out zones where family values, youth values, and the blessings of quiet seclusion and clean air make the area a sanctuary for people. ${ }^{312}$

Consequently, in Boraas the Supreme Court adhered to its permissive view of governmental goals as expressed earlier in Berman v. Parker. Despite the exclusionary effect of the zoning ordinance, the Court upheld it because it rationally furthered a legitimate goal. ${ }^{313}$ The environmental values espoused by the village were permissible, and the Court would not overturn the ordinance because it had the effect of promoting social homogeneity. Federal court intervention would be warranted only if a fundamental interest were infringed $^{314}$ or a suspect classification were involved. Environmental purposes would be treated with the same kind of judicial deference traditionally granted to social and economic legislation, ${ }^{315}$ even if the result were the exclu-

307. Id.

308. Id.

309. Id. at 7 .

310. Id. at 8 .

311. Id. at 9 .

312. Id.

313. Apparently, the entire Court was in agreement on this issue. The dissenters argued that the legitimate goal intruded upon basic freedom of association values. $/ d$. at 13 (Marshall, J., dissenting).

314. Whether or not a fundamental interest was at stake seems to be the issue that separated the majority and the dissent. See Moore v. City of East Cleveland, 431 U.S. 494, 498-506 (1977) (plurality opinion).

315. Cf. Steel Hill Dev., Inc. v. Town of Sanbornton, 469 F.2d 956 (1st Cir. 1972) (upholding large-lot zoning because of potentially hazardous environmental impact). 
sion of certain groups who might be "uncongenial"316 to the residents of Belle Terre. In short, the federal constitution was no bar to a local community's action to preserve its own character.

The extent to which the Supreme Court would accept a character of the community rationale was demonstrated in Young $v$. American Mini Theatres, Inc. ${ }^{317}$ in which the Court held valid Detroit's zoning restrictions on adult movie theatres. In Young, Detroit sought to disperse adult movie theatres (those exhibiting sexually explicit films) as part of a campaign to combat neighborhood deterioration. Presumably, the concentration of certain types of businesses in an area adversely affects property values and promotes neighborhood instability. ${ }^{318}$

It is not surprising that the Court found the anti-skid row purpose of the zoning ordinance valid. ${ }^{319}$ Given Euclid and Boraas, it is also not surprising that the Court would "accord[] high respect" to "the city's interest in attempting to preserve the quality of urban life." 320 What is dramatic about the Young decision is that in "requir[ing] adult theatres to be separated rather than concentrated in the same areas," ${ }^{21}$ Detroit was drawing a legislative distinction based on the content of the expressive activity regulated, a practice that many had thought to be precluded by the First Amendment. ${ }^{322}$

The Court acknowledged that First Amendment values were implicated by Detroit's zoning ordinance since the materials exhibited in adult movie houses were not legally obscene. ${ }^{323}$ Justice Stevens, for the plurality, concluded that legislation can classify expressive activity on the basis of content, provided there is no breach of "government's paramount obligation of neutrality in its regulation of protected communication," 324 and provided further that the classification can be "justified by the city's interest in preserving the character of its neighborhoods." 325

The Court resolved Young by using a balancing analysis. Justice Stevens

\footnotetext{
For state court treatments of environmental factors in a land use context, see e.g., SAVE A VALUABLE ENVIRONMENT v. City of Bothell, 89 Wash.2d 862, 576 P.2d 401 (1978) (holding that a municipality has a duty to serve regional welfare when the interest at stake is the quality of the environmenent); Just v. Marinette County, 56 Wis.2d 7, 201 N.W.2d 761 (1972).

316. 416 U.S. at 7.

317. 427 U.S. 50 (1976).

318. Id. at 55 .

319. Id. at 71. Justice Powell joined the plurality on this point. Id. at $73-74,80$ (Powell, J., concurring).

320. Id. at 71 .

321. Id.

322. The Court had previously held that "above all else, the First Amendment means that government has no power to restrict expression because of its message, its ideas, its subject matter, or its content." Police Dep't v. Mosley, 408 U.S. 92, 95 (1972). Justice Stewart, for the four dissenters, called the majority's decision "an aberration." 427 U.S. at 87 (Stewart, J., dissenting).

323. 427 U.S. at 62.

324. Id. at 70 .

325. Id. at 71 .
} 
disparaged the magnitude of the First Amendment interests involved by noting that society's stake in the exhibition of erotic materials was much less substantial than its interest in political expression. ${ }^{326} \mathrm{He}$ also noted that the zoning ordinance did not totally suppress communication, but rather limited the place where adult films could be exhibited ${ }^{327}$ In this way, Justice Stevens (and Justice Powell in his pivotal concurring opinion ${ }^{328}$ ) diminished the weight to be accorded the interests in free expression that were impaired by the Detroit ordinance.

At the same time, Justice Stevens was studiously vague in determining how important the city's interests had to be in order to justify infringement of even the diminished First Amendment interests involved. ${ }^{329}$ The Court's plurality opinion simply stated that the Court would not "appraise the wisdom ${ }^{350}$ of the ordinance but that "the [c]ity's interest in the present and future character of its neighborhoods adequately supports its classification of motion pictures."331 The opinion refrained from endorsing the entirely permissive standard applied to social and economic legislation adopted in Boraas, but it articulated only the conclusory finding that the city's justification was "adequate." 322

The Young decision is significant in the context of this Subsection because of its broad deference to governmental zoning goals and its willingness to permit these objectives to prevail even in the face of a confrontation between zoning and fundamental First Amendment values. Both the Stevens plurality

326. Id. at 70. As Justice Stevens put it, "few of us would march our sons and daughters off to war to preserve the citizen's right to see 'Specified Sexual Activities' exhibited in the theatres of our choice." Id. The dissent sharply criticized "such majoritarian limitations on individual liberty," stating that, "if the guarantees of the First Amendment were reserved for expression that more than a 'few of us' would take up arms to defend, then the right of free expression would be defined and circumscribed by current popular opinion." Id. at 86 (Stewart, J., dissenting).

327. Id. at 71 .

328. Id. at 77-78 (Powell, J., concurring).

329. Justice Powell avoided this form of balancing by adopting the four-part test of United States v. O'Brien, 391 U.S. 367, 377 (1968), a draft-card burning case. Under O'Brien, governmental regulation is justified, despite incidental impact on speech interests, " if it is within the constitutional power of the Government; if it furthers an important or substantial governmental interest; if the governmental interest is unrelated to the suppression of free expression; and it the incidental restriction on ... First Amendment freedoms is no greater than is essential to the furtherance of that interest." " 427 U.S. at 79-80, (Powell, J., concurring) (quoting 391 U.S. at 377). Justice Powell concluded that the zoning regulation passed constitutional muster under these criteria. 427 U.S. at 80.

330. Id. at 71 .

331. Id. at 72 .

332. Id. Certainly Justice Stevens steered far clear of the compelling interest formula that might be expected in a first amendment context. See, e.g., Police Dep't v. Mosley, 408 U.S. 92 (1972). Cf. Linmark Assocs. Inc. v. Township of Willingboro, 431 U.S. 85, 95 (1977) (ban on real estate "For Sale" signs, which had an impact on the free flow of public information, must be justified by an overriding governmental objective); Buckley v. Valeo, 424 U.S. 1, 25 (1976) (campaign finance law, which implicated fundamental first amendment interests, could be sustained only if government showed a sufficiently important interest and used narrowly drawn means). 
and the Powell concurring opinions evince great deference to a city's use of its zoning authority to combat "serious problems" ${ }^{333}$ and to promote interests that are "both important and substantial." 334 In the face of serious First Amendment questions, Young makes it clear that the Court is disinclined to intervene in the zoning process, absent more direct and pervasive intrusion on basic constitutionally protected interests. ${ }^{335}$

The deference to governmental land use decisions reflected in Euclid, Boraas and Young indicates that the Supreme Court is unwilling to develop Constitutional doctrines that would limit local growth management initiatives by aggressively barring exclusionary land use practices. It is only with respect to decisions based on racial criteria that the Court has agreed to intervene. ${ }^{336}$

The Court's concern about race-based zoning dates to its 1917 decision in Buchanan $v$. Warley, ${ }^{337}$ in which the racial grounds of classification in the land use scheme were explicit. After the desegregation cases, ${ }^{338}$ it comes as no surprise that an identifiably racial criterion for governmental action would be treated as suspect, reversing the ordinary presumption of validity and shifting the burden onto the locality to show that use of a racial classification was necessary to promote a compelling or overriding governmental interest. ${ }^{339}$ The issue in the zoning context was what standard would be applied to determine whether or not a measure was racially discriminatory. ${ }^{340}$

It is here that the adoption of either a purpose or an effect test is so important. Some federal cases had suggested that "the substantially disproportionate racial impact of a statute or official practice standing alone and without regard to discriminatory purpose, suffices to prove racial discrimination $\ldots . .^{341}$ In Washington $v$. Davis ${ }^{342}$ the Court rejected the unequal impact rule ${ }^{343}$ as a means of establishing racial discrimination. Justice White, for the major-

333. 427 U.S. at 71 (per Stevens, J.) (plurality opinion).

334. Id. at 80 (Powell, J., concurring).

335. See, e.g., Moore v. City of East Cleveland, 431 U.S. 494 (1977) (invalidating a zoning law that had the effect of prohibiting extended families from living in the same dwelling unit); Linmark Assocs., Inc. v. Township of Willingboro, 431 U.S. 85 (1977) (invalidating a ban on real estate "For Sale" signs, which was designed to promote stable, integrated housing, because ordinance impermissibly interfered with the flow of commercial communication).

336. See Village of Arlington Heights v. Metropolitan Hous. Dev. Corp., 429 U.S. 252 (1977). But see Moore v. City of East Cleveland, 431 U.S. 494 (1977) (plurality opinion). Moore, which is idiosyncratic, is not without its racial overtones. See id. at 508-10 (Brennan, J., concurring).

337. 245 U.S. 60 (1917).

338. E.g., Keyes v. School Dist. No. 1, 413 U.S. 189 (1973); Loving v. Virginia, 388 U.S. 1 (1967); McLaughlin v. Florida, 379 U.S. 184 (1964); Brown v. Board of Education, 347 U.S. 483 (1954).

339. See Developments in the Law-Equal Protection, 82 Harv. L. REv. 1065, 1101 (1969) [hereinafter cited as Equal Protection Development ].

340. See generally Mandelker, supra note 293, at 1236-42.

341. Washington v. Davis, 426 U.S. 229, 244 (1976).

342. 426 U.S. 229 (1976).

343. Id. at 247-48 and n.14. 
ity, concluded that proof of discriminatory purpose was a necessary ingredient in a finding of racial discrimination. ${ }^{344}$ The Washington Court declined to hold suspect a "statute designed to serve neutral ends . . . if in practice it benefits or burdens one race more than another. . . "345

A year prior to the Washington decision, the Supreme Court had dismissed a broad challenge to a suburban land use scheme on the ground that the many and varied plaintiffs lacked standing. ${ }^{346}$ That often criticized opinion, ${ }^{347}$ to be discussed in Subsection C.2. ${ }^{348}$ can be seen in retrospect as something of a holding action, signaling the Court's unwillingness to adjudicate broad-scale social issues in the suburban zoning context, at least until a consensus had been forged on substantive doctrine. This was recognized by Justice Douglas, who in dissent thought the majority "read[] the complaint and the record with antagonistic eyes," 349 and by Justice Brennan, who noted in dissent that " $[w]$ hile the Court gives lip service to the principle . . . that 'standing in no way depends on the merits of the plaintiff's contention that particular conduct is illegal,' . . . in fact the opinion . . . can be explained only by an indefensible hostility to the claim on the merits." 350

The standing requirement in Warth-that a zoning challenge be projectbased-was consistent with the purpose analysis subsequently adopted in Washington for proving racial discrimination. The Court, in the term following the Washington decision, had the opportunity to apply its criteria in the land use setting. Village of Arlington Heights v. Metropolitan Housing Development Corp. $^{351}$ involved a challenge to a suburb's refusal to rezone a fifteen acre parcel from a single-family to a multifamily classification, a change that would accommodate a proposed housing development for low and moderate income tenants. ${ }^{352}$ The existence of a project proposal and the leasing of a specific site satisfied the Warth standing criteria, ${ }^{353}$ and the Court proceeded, on the merits, to rely on Washington's holding "that official action will not be held unconstitutional solely because it results in a racially disproportionate impact." ${ }^{354}$ In order to find a federal constitutional violation of equal protection, "[p]roof of racially discriminatory intent or purpose is required." 355

344. Id. at $239-48$.

345. Id. at 248.

346. Warth v. Seldin, 422 U.S. 490 (1975).

347. See L. Tribe, American Constitutional Law \$3-21 (1978) ("[O]ne can only regard as aberrational in the extreme the decision in Warth v. Seldin . . . .); Sager, supra note 291, at 1376-1402.

348. See Section V.C.2. infra.

349. 422 U.S. at 518 (Douglas, J., dissenting).

350. Id. at 520 (Brennan, J., dissenting) (quoting majority opinion, id at 500).

351. 429 U.S. 252 (1977).

352. Id. at 254.

353. See Section V.C.2. infra.

354. 429 U.S. at 264-65.

355. Id. at 265. 
Arlington Heights makes explicit in the land use area that, as a matter of federal constitutional law, no affirmative duty exists for suburban communities to accommodate multifamily dwellings. All that plaintiffs can expect from federal courts is that they will police suburban land use practices intended to discriminate against racial minorities.

Arlington Heights indicates that a plaintiff need not prove that a "challenged action rested solely on racially discriminatory purposes. . . . or even that a particular purpose was the 'dominant' or 'primary' one."356 On the other hand, a showing that "a discriminatory purpose has been a motivating factor in the decision" 357 does not end the analysis. A community still has the opportunity to establish that the "same decision would have resulted even had the impermissible purpose not been considered." 358 Consequently, the discriminatory purpose must indeed be the proximate cause of the challenged action, but, once a prima facie case is established, the burden of persuasion on the issue of causation rests with the local government. ${ }^{359}$

The prima facie case of discriminatory purpose can be established in a variety of ways. Where "a clear pattern, unexplainable on grounds other than race, emerges from the effect of the state action," 360 an inference of impermissible purpose is possible, but Justice Powell noted that "such cases are rare" ${ }^{, 31}$ and made it clear that the pattern of proof must be "stark." ${ }^{62}$ Other factors to consider are the historical background, the "specific sequence of events leading up to the challenged decision," ${ }^{363}$ a deviation from normal procedural practices, a departure from substantive criteria applied elsewhere, and the legislative or administrative history (including minutes of meetings or legislative reports). ${ }^{364}$

356. Id

357. Id. at $265-66$.

358. Id. at $270 \mathrm{n} .21$.

359. Id. This is the analytical mode established in Mt. Healthy City Bd. of Educ. v. Doyle, 429 U.S. 274 (1977). There, the Court indicated that when a teacher made out a prima facie case that his termination by the school board had been impermissibly motivated by considerations barred by the first amendment, the school board still had an opportunity to show that the teacher would have been fired on permissible grounds. That is, the initial burden is placed upon a plaintiff to show improper motivation. If this is satisfied, the government must show by a preponderance of the evidence that it would have acted in the same manner on totally permissible grounds. $I d$. at 287.

360. 429 U.S. at 266 .

361. Id.

362. Id. Justice Powell cited the decision in Gomillion v. Lightfoot, 364 U.S. 339 (1960), to indicate just how stark the facts must be. In Gomillion a state legislature redrew a city's boundaries, altering the shape from a square to an irregular twenty-eight-sided figure. $I d$. at 340 . The gerrymandering removed from the city all but a handful of its 400 black voters while not a single white voter was affected. Id. at 341 . This deprivation of the blacks' preexisting municipal vote was found to violate the fifteenth amendment. Id. at 346 .

363. 429 U.S. at 267.

364. Id at 266-68. 
Specification of the factors that can lead to a finding of racially discriminatory purpose has both attractions and drawbacks from a complainant's perspective. It does provide guidance with respect to presenting proof and indicates that circumstantial evidence is probative. ${ }^{365}$ It also, however, furnishes well-counseled municipalities with a virtual handbook for duplicity, allowing communities to excise reference to race from the public record and encouraging them at the same time to fill the record with boilerplate so that, if a prima facie case is established, ample rebuttal evidence on proximate causation will be available.

The narrowness of the Washington-Arlington Heights doctrine is apparent. Disproportionate impact, what the Court has labeled the "naked statistical argument," 366 will not permit judicial intervention even if the disproportionate effect on racial or certain socioeconomic groups is foreseeable. ${ }^{367}$ Thus, the Court has rejected a claim that a program that treated Aid to Families with Dependent Children (AFDC) recipients (predominantly blacks and MexicanAmericans) worse than other categorical assistance beneficiaries resulted in a racial classification. ${ }^{368}$ It has declined to infer race discrimination from a referendum requirement for approving the construction of low income housing, refusing to draw the nexus between socioeconomic status and race. ${ }^{369}$

Justice Stewart recently noted, in a claimed gender-based discrimination context, that "[t]he calculus of effects, the manner in which a particular law reverberates in a society, is a legislative and not a judicial responsibility." 370 That comment characterizes accurately the approach of the Supreme Court in reviewing legislative classifications in the land use field..$^{371}$ The Court has been extremely reticent to intervene, restricting its role to policing against race discrimination. Even then, it has applied a narrow interpretation of what constitutes race discrimination. It has required a showing that a course of con-

365. Justice Stevens emphasized this point in his Washington concurrence. 426 U.S. at 253. And, presumably, this explains the partial concurrence by Justices Marshall and Brennan in Arlington Heights. See 429 U.S. at 27 1-72 (Marshall, J., concurring).

366. Jefferson v. Hackney, 406 U.S. 535, 548 (1972).

367. See Personnel Adm'r v. Feeney, 99 S. Ct. 2282, 2295-96 (1979).

368. See Jefferson v. Hackney, 406 U.S. 535 (1972).

369. See James v. Valtierra, 402 U.S. 137 (1971). Cf. Hunter v. Erickson, 393 U.S. 385 (1969) (explicit racial classification). For further discussion of these points, see Blumstein, Constitutional Prespectives on Governmental Decisions Affecting Human Life and Health, 40:4 Law \& ContemP. Prob., Autumn 1976, at 231, 289-93 (1976); Eisenberg, Disproportionate Impact and Illicit Motive: Theories of Constitutional Adjudication, 52 N.Y.U. L. REv. 36, 43-50 (1977); Perry, The Disproportionate Impact Theory of Racial Discrimination, 125 U. PA. L. Rev. 540, 582-89 (1977).

370. Personnel Adm'r v. Feeney, 99 S. Ct. 2282, 2292 (1979). For a discussion of genderbased discrimination prior to and consistent with Feeney, see Blumstein, supra note 369, at 293-97.

371. Some courts have recognized the implications of the intent-based standard for proving race discrimination and have found such a view to be excessively narrow in interpreting the federal Fair Housing Act. See, e.g., Metropolitan Hous. Dev. Corp. v. Village of Arlington Heights, 558 F.2d 1283, 1289 (7th Cir. 1977), cert. denied, 434 U.S. 1025 (1978). See also Section VI.A infra. 
duct was pursued 'at least in part 'because of,' not merely 'in spite of,' its adverse effects upon an identifiable group." ${ }^{372}$ The Court has also provided ample opportunity to local governments to develop an antiseptic record that can either refute an inference of racial motivation or can justify their actions (even if race discrimination is actually found as a motivating factor). Clearly, concern with the effects of legislative actions on low and moderate income groups is deemed a political matter not warranting federal judicial intercession. The scrutiny of legislative purposes is minimal and the deference to legislative judgments is extraordinary except where there is proof of racially discriminatory motivation, in which case such deference "is no longer justified." 373

\section{B. The Scope of the Appropriate Constituency}

Despite the dictum in Euclid that regional interests might require, in some circumstances, the subordination of local welfare to that of a broader public, the Supreme Court has declined to expand the scope of the relevant constituency in reviewing local land use cases. This general reticence to broaden the scope of the appropriate constituency beyond state-defined geographical boundaries is also reflected in the analogous voter qualification cases. This Subsection will consider both lines of cases.

In Boraas $^{374}$ the village-imposed zoning limitation on households having more than two unmarried persons was considered entirely within the context of the general welfare of the village of Belle Terre, the enacting community. This lesson of Boraas was not lost on the ninth circuit when it heard a challenge to the growth limitation plan adopted by the California city of Petaluma. ${ }^{375}$ Facing rapid population growth as it became part of the San Francisco Bay Area metropolitan housing market, Petaluma temporarily froze development. ${ }^{376}$ After a study of the recent housing growth in the community, the city imposed (ostensibly for a five-year period) a housing development cap at $500 \mathrm{dwelling}$ units per year. ${ }^{377}$ The trial court found that the growth limitation was enacted to restrict the rate of increase in new housing and to control the rate of population growth through in-migration. ${ }^{378}$ The evidence indica-

372. $99 \mathrm{~S}$. Ct. at 2296 .

373. 429 U.S. at 266.

374. Village of Belle Terre v. Boraas, 416 U.S. 1 (1974).

375. Construction Indus. Ass'n v. City of Petaluma, 522 F.2d 897 (9th Cir. 1975), cert. denied, 424 U.S. 934 (1976).

376. Id. at 900 .

377. Id. at 901 . The city's growth plan also provided for the following: a "greenbelt" to circle the city and contain expansion; an intricate point system whereby a builder obtained building permits by conforming to city environmental, social, aesthetic and recreational goals; an even geographical distribution of development; and a guaranteed amount of low and moderate income housing. The city also solicited the county to take appropriate measures in areas outside the city in order to facilitate the city's plans. $I d$.

378. Id. at 902 (citing Construction Indus. Ass'n v. City of Petaluma, 375 F. Supp. 574, 576 
ted that if Petaluma's program were enacted by other municipalities throughout the region, "the impact on the housing market would be substantial." 379 With respect to the city of Petaluma alone, however, no decrease in housing opportunities for low and middle income persons would result because the plan increased the availability in Petaluma of multifamily units. ${ }^{380}$ Since the trial court found that Petaluma enacted the growth control cap for the purpose of excluding people who otherwise would have moved to the city and that the cap had that exclusionary effect, plaintiffs argued that the plan was invalid. ${ }^{381}$ The ninth circuit, however, concluded that a finding of exclusionary purpose or effect did not end the analysis. Rather, the panel proceeded to "determine ... whether the exclusion bears any rational relationship to a legitimate state interest." ${ }^{382}$ If the housing cap promoted a legitimate interest of the enacting community, the court would defer to the legislative judgment. ${ }^{383}$

Relying on Boraas ${ }^{384}$ the court held that preserving the small town character of the community and avoiding "uncontrolled and rapid growth" were within the police power as "within the broad concept of "public welfare'." 385 Even though Petaluma's action adversely affected regional housing conditions by curtailing increases in supply, the ninth circuit declined to invalidate the Petaluma plan because of its regional impact.

[U]nilateral land use decisions by one local entity affect the needs and resources of an entire region. [citations omitted] It does not necessarily follow, however, that the due process rights of builders and landowners are violated merely because a local entity exercises in its own self-interest the police power lawfully delegated to it by the state. [citations omitted] If the present system of delegated zoning power does not effectively serve the state interest in furthering the general welfare of the region or entire state, it is the state legislature's and not the federal court's role to intervene and adjust the system. ${ }^{386}$

(N.D. Cal. 1974)). The 500-unit cap reflected a fifty percent reduction in the rate of increase in the two years immediately prior to adoption of the plan. That figure may be exaggerated, however, because the cap excluded residential developments of fewer than five units. 522 F.2d at 901-02.

379. Id. at 902 .

380. Id.

381. See text accompanying notes 341-73, 378-79 supra.

382. 522 F.2d at 906 (italics in original).

383. Id. The plaintiffs in Petaluma, two landowners and a building association, asserted a constitutional right to travel claim. As the court found that the plaintiffs' legitimate economic interests fell "outside the zone of interest to be protected by any purported constitutional right to travel," id. at 904, that claim fell within the prudential limitation on standing established by the Supreme Court in Warth v. Seldin, 422 U.S. 490 (1975). (See text accompanying notes $445-54$ infra.) Plaintiffs were barred from asserting the rights of newcomers in order to obtain relief from injury to themselves. This could be done only by "those individuals whose mobility is impaired." 522 F.2d at 904.

384. Village of Belle Terre v. Boraas, 416 U.S. 1 (1974). See also Ybarra v. City of Los Altos Hills, 503 F.2d 250 (9th Cir. 1974).

385. 522 F.2d at 906 .

386. Id. at 908 . 
Thus, the ninth circuit explicitly declined to expand the scope of its analysis of the public welfare concept to incorporate regional as well as local interests. It refused to place itself in the position of determining "the point at which legitimate local interests in promoting the welfare of the community are outweighed by legitimate regional interests, ${ }^{387}$ implicitly rejecting the invitation suggested by the dictum in Euclid.

The extent of the Supreme Court's refusal to establish a locality's duty to accommodate broader regional interests is reflected not only in its willingness to impose regional criteria in reviewing local land use regulations but also in its recent decisions in the analogous voting rights area ${ }^{388}$ Despite the evolution of a strict standard of review in cases where residents are selectively excluded from the franchise, the Court has been unwilling to extend the doctrine of the voter qualification cases to recognize interests of nonresidents. Even when a city has legislative police power authority over an extraterritorial area whose geographical boundaries are definitively established by state legislation, the Court has declined to apply the rationale of the voter qualification cases. Consequently, residents in extraterritorial areas, who are bound by municipal decisions but who do not participate in municipal elections, have not been accorded the benefit of the stricter standard of review applied in voter qualification cases. Because of the close analytical parallels between the extraterritorial voting rights situation and the regional focus in the land-use context, the voting rights developments are worthy of attention in considering the Court's treatment of the constituency issue.

In a line of cases commencing with Carrington v. Rash ${ }^{389}$ in 1965, the Supreme Court held invalid a variety of restrictions on voter qualifications. In Carrington, Texas had precluded servicemen from ever acquiring resident status for voting purposes if, prior to entering the service, they had not been Texas residents. ${ }^{390}$ The Court held that this form of classification-based on a "conclusive presumption that their necessarily transient status precluded them from being bona fide residents" 391 — violated equal protection since it affected the ability of servicemen to vote-that is, to exercise their fundamental interest in participating in the political process.

Carrington was followed by a series of $\operatorname{cases}^{392}$ that established the general

387. Id. The Court was adamant in its refusal to sit as "a super zoning board." Id. Although it recognized that present methods of supplying housing in metropolitan areas were inadequate, the Court found the extensive controversy aroused by the Petaluma litigation to be "compelling evidence that resolution of the important housing and environmental issues raised here is exclusively the domain of the legislature." Id. at 909 n.17. See generally Note, supra note 241, at 605-11.

388. See generally Blumstein, The Supreme Court and Voter Eligibility, in Issues of ElectoraL ReForm 74 (R. Carlson ed. 1974).

389. 380 U.S. 89 (1965).

390. Id.

391. Town of Lockport v. Citizens For Community Action, 430 U.S. 259, 267 n.12 (1977).

392. E.g., Hill v. Stone, 421 U.S. 289 (1975); Dunn v. Blumstein, 405 U.S. 330 (1972); City of 
proposition that since "statutes distributing the franchise constitute the foundation of our representative society," 393 such statutes are subject to "exacting judicial scrutiny." 394 Consequently, where a statute selectively distributes the franchise, the exclusion of some potentially qualified voters can only be justified if "necessary to promote a compelling state interest," ${ }^{395}$ the traditional formula for strict scrutiny. ${ }^{396}$

These voter qualification cases recognized that the state could limit participation in an election to those "primarily interested" or "primarily affected,"397 and they all involved situations where the challenge was brought by a potential voter who met the basic age, citizenship and residency requirements for voting. ${ }^{398}$ Nevertheless, recognition of the stake of potential residents in the land use decision making process of local governments ${ }^{399}$ led some to the conclusion that the voter qualification cases offered a mechanism for the Court to impose a broader voting constituency on local governments, at least in situations where external interests in local land use decision-making were discernible. ${ }^{400}$ Such expansion of the voting constituency would presumably increase the legitimacy of the locality's land use decisions.

Even proponents of the use of the voter qualification cases in the local zoning context acknowledged that the appropriate remedies-"provid[ing] outsiders access to suburban communities or ... enlarg[ing] the constituency by drawing new jurisdictional lines" ${ }^{401}$ - were cumbersome for courts to order. Instead, the recommendation was that a court hold invalid the existing system, "explain the principles upon which it bases it decision," 402 and allow the legislature to provide a solution within the framework enunciated by the court. $^{403}$

One of the major practical difficulties in fashioning judicial relief in such a hypothetical challenge is to determine the scope of the affected constituency

Phoenix v. Kolodziejski, 399 U.S. 204 (1970); Evans v. Cornman, 398 U.S. 419 (1970); Cipriano v. City of Houma, 395 U.S. 701 (1969); Kramer v. Union Free School Dist., 395 U.S. 621 (1969). But see Associated Enterprises, Inc. v. Toltec Watershed Improv. Dist., 410 U.S. 743 (1973); Salyer Land Co. v. Tulare Water Dist., 410 U.S. 719 (1973). See generally Blumstein, supra note 388 .

393. Kramer v. Union Free School Dist., 395 U.S. 621,626 (1969).

394. Id. at 628 .

395. Id. at 627 (citing to Carrington v. Rash, 380 U.S. 89 (1965)).

396. See Dunn v. Blumstein, 405 U.S. 330,337 (1972). See generally Equal Protection Development, supra note 339 , at $1120-22$.

397. 395 U.S. at 632. See Associated Enterprises, Inc. v. Toltec Watershed Improv. Dist., 410 U.S. 743 (1973); Salyer Land Co. v. Tulare Water Dist., 410 U.S. 719 (1973).

398. E.g., 395 U.S. at 625

399. See Note, supra note 193.

400. See Note, The Constitutionality of Local Zoning, 79 Y ALE L.J. 896 (1970).

401. Id. at 923 .

402. Id. at 924 .

403. Id. 
beyond the local unit's boundaries ${ }^{404}$ Applying the strict scrutiny standard within a fixed, legislatively determined geographic area is considerably more manageable than ranging into the fine calculations necessary to determine who should participate in the political process of a community because she is affected by its decisions. ${ }^{405}$

In a real sense, then, if the voter qualification cases were to be applied to a claim by nonresidents that they be permitted to participate in a community's political process, the most likely candidate for success would be a situation in which the legislature had exhaustively defined the geographical limits of the extraterritorial area. Specifically, where a city is granted extraterritorial police power over a defined area whose residents have no voice in the city's political arena, one would think that extension of the rationale of the voter qualification cases would be most acceptable from the perspective of judicial manageability. Although the existing political constituency would be expanded, the courts would have clear, legislatively-determined boundaries to confine the scope of judicial discretion in formulating a remedy. ${ }^{\mathbf{4 0 6}}$

The Court's reluctance to interfere with the autonomy of the political structure of local units of government, ${ }^{407}$ even in the most favorable paradigm case, was evidenced recently in Holt Civic Club $v$. City of Tuscaloosa, ${ }^{408}$ in which the Court rejected a challenge by nonresidents of Tuscaloosa to the city's exercise of the police power over them. Alabama statutes granted Tuscaloosa specified police powers over nonresidents living within three miles

404. This, of course, has been a major difficulty for the states that have adopted the regional fair share concept. See, e.g., Associated Home Builders v. City of Livermore, 18 Cal.3d 582, 608, 557 P.2d 473, 488, 135 Cal. Rptr. 41, 56 (1976); Oakwood at Madison, Inc. v. Township of Madison, 72 N.J. 481, 498-500, 371 A.2d 1192, 1200-01 (1977); Southern Burlington County NAACP v. Township of Mount Laurel, 67 N.J. 151, 189-190, 336 A.2d 713, 733 (1975), appeal dismissed, 414 U.S. 12 (1975). For federal treatment of similar issues see Kollar v. City of Tucson, 319 F. Supp. 482 (D. Ariz. 1970), aff'd mem., 402 U.S. 967 (1971). The problem of defining a "region" has elicited a considerable amount of commentary. E.g., Ackerman, supra note 134, at 24-27; Rose, supra note 137, at 717-20.

405. This point was emphasized in the voter residency litigation. See Appellee's Brief at 26-28, Dunn v. Blumstein, 405 U.S. 330 (1972).

406. Cf. Wright v. Council of Emporia, 407 U.S. 451 (1972) (city school district not allowed to secede from county system when to do so would impair effectiveness of court-ordered desegregation of county system). The Court's task was made easier by the state's definition of the county as the appropriate original jurisdiction for a school district. See also United States v. Scotland Neck Bd. of Educ., 407 U.S. 484 (1972).

407. See Hunter v. City of Pittsburgh, 207 U.S. 161, 178-79 (1907) ("Municipal corporations are political subdivisions of the State, created as convenient agencies for exercising such of the governmental powers of the State as may be entrusted to them. . . [T] ... may do as it will [with these corporations], unrestrained by any provision of the Constitution of the United States.") But cf. Kramer v. Union Free School Dist., 395 U.S. 621 , 628 n.10 (1969) ("'[S]tatutes structuring local government units receive no less exacting an examination merely because the state legislature is fairly elected."); Avery v. Midland County, 390 U.S. 474, 481 n.6 (1968) ("Inequitable apportionment of local governing bodies offends the Constitution. . .").

408. 439 U.S. 60 (1978). 
of the city, provided the areas were unincorporated; these nonresidents were ineligible to vote in city elections.

In upholding the Alabama statute the Court noted that the voter qualification cases all had a "common characteristic," 409 namely "the challenged statute in each case denied the franchise to individuals who were physically residents within the geographic boundaries of the governmental entity concerned." 410 Justice Rehnquist, for the majority, was clearly concerned with the practical difficulties of abandoning the residency criterion that had been accepted in prior cases. ${ }^{411} \mathrm{He}$ did not even mention the three-mile geographical limitation contained in the Alabama statute, concluding instead that the voting qualification cases would be confined to situations where the potential voter is a resident of "the geographical boundary of the governmental unit at issue." 412

In this way, the issue in Holt was "stripped of its voting rights attire,"413 and the Court proceeded to emphasize its reluctance, despite the reapportionment and voting qualification cases, to intrude on "the extraordinarily wide latitude that states have in creating various types of political subdivisions and conferring authority upon them."414 Accordingly, the Court applied its most deferential form of rationality standard ${ }^{415}$ and concluded that the statute's provisions were rational.

Justice Brennan noted in dissent that "[t]he criterion of geographical residency is . . . entirely arbitrary when applied to this case." ${ }^{116}$ By refusing to apply the strict scrutiny of the voting qualification cases, he argued, "the court cede[d] to geography a talismanic significance contrary to the theory and meaning of our past voting rights cases." ${ }^{417}$ The criterion of residency was approved in earlier cases, according to Justice Brennan, because it helped define the relevant political community. Since such a community depends, for its legitimacy, on "the notion of a reciprocal relationship between the process of government and those who subject themselves to that process by choosing to

409. Id. at 86 .

410. Id. An interesting parallel, not mentioned by the majority or the dissent, is the racial gerrymandering of Tuskegee, Alabama, held violative of the fifteenth amendment in Gomillion v. Lightfoot, 364 U.S. 339 (1960). If a nonresident has no constitutionally-protected interest in voting in a particular geographic constituency, it is difficult to see how this fifteenth amendment right to vote has been impaired by a racial gerrymander. See note 362 supra.

411. E.g., Dunn v. Blumstein, 405 U.S. 330, 343-44 (1972); Evans v. Cornman, 398 U.S. 419 , 422 (1970); Kramer v. Union Free School Dist., 395 U.S. 621,625 (1969); Carrington v. Rash, 380 U.S. 89,91 (1965).

412. 439 U.S. at 70 .

413. Id.

414. Id. at 71 .

415. According to the Court "[a]uthority to make those [governmental structure] judgments resides in the state legislature, and Alabama citizens are free to urge their proposals to that body. ... Our inquiry is limited to the question whether 'any state of facts reasonably may be conceived to justify' Alabama's system of police jurisdictions. ..." Id. at 74 (citations omitted).

416. Id. at 89 (Brennan, J., dissenting).

417. Id. at 81 . 
live within the area of its authoritative application," 418 the dissent argued that "[s]tatutes . . . which fracture this relationship by severing the connection between the process of government and those who are governed in the places of their residency . . . undermine the very purposes . . . [for approving] . . bona fide residency requirements." 419

Moreover, pragmatically, the plaintiffs actually lived within the geographic boundaries established by the state for the exercise of extraterritorial authority. In that sense, the challengers had, for the dissent, a valid claim to residency status within the area of Tuscaloosa's police power authority.

If the Court were inclined to extend the doctrine established in the voting qualification cases, Holt would have been a good candidate for many of the reasons voiced by Justice Brennan in his cogent dissent. The depth of the Court's disinclination to impose obligations on localities to nonresidents is evident from the extraordinarily restrained review applied in Holt, reminiscent of the highly deferential formulation in Boraas. ${ }^{420}$ Consequently, in both the zoning and the voting qualification contexts the Court has been unwilling to intervene to curtail local autonomy in the name of those whose interests are affected but who are not participants in the local unit's political process. ${ }^{421}$ Quite clearly, this federal judicial posture is at odds with the stance adopted by the courts in Pennsylvania and New Jersey, and even by the courts in New York and California.

\section{Remedial and Procedural Issues}

Substantively, the Supreme Court has been extremely reticent to intervene in local land use decisions. Only racial classifications have been more than minimally scrutinized ${ }^{42}$ and the Court has steadfastly declined to infer racial classifications from evidence of disproportionate impact. ${ }^{423}$ In addition, the

418. Id. at 82

419. Id.

420. See Village of Belle Terre v. Boraas, 416 U.S. 1, 9 (1974). Holt was not, however, a complete blank check approval of municipal extraterritorial power over bordering areas. See 439 U.S. $60,72-73$ n.8 (1978). The Court suggested that the extraterritorial powers of cities might not "pass constitutional muster" if they included "the vital and traditional authorities of cities and towns to levy ad valorem taxes, invoke the power of eminent domain, and zone property for various types of uses." Id. The dissent would have characterized the Holt situation as such a case, see id. at $82 \mathrm{n} .9$ (Brennan, J., dissenting), since the challenged statute "sever[ed] the connection between the process of government and those who are governed in the places of their residency ...."Id. at 82 .

421. For another example of deference to state structural decisions in the voting context, see Town of Lockport v. Citizens for Community Action, 430 U.S. 259 (1977) (upholding dual city and county majority for adoption of charter). Cf. Mahan v. Howell, 410 U.S. 315 (1973) (showing deference to county political boundaries in a reapportionment context); Abate v. Mundt, 403 U.S. 182 (1971) (permitting deviation from one person, one vote standard because of historical functional interdependence of county and town subdivisions in New York).

422. But see Moore v. City of East Cleveland, 431 U.S. 494 (1977); Zoning Development, supra note 290 , at $1568-74$.

423. See text accompanying notes $366-67$ supra. 
Court has refused to impose a duty on local governments to accommodate regional interests. These developments in the evolution of substantive doctrine are paralleled in the Court's narrowing of its role: (1) in ordering remedies for constitutional violations of a municipality beyond its borders; (2) in allowing litigants standing to challenge the validity of allegedly unconstitutional local zoning ordinances; and (3) in sustaining zoning procedures that may adversely affect the interests of landowners and potential residents by committing zoning decisions to the vicissitudes of ad hoc political decision making through the referendum process. Decisions in each of these areas will be considered in turn.

\section{Extraterritorial Remedies}

In declining to impose regional obligations on local governments, the Court has narrowly circumscribed its role in reviewing local government land use decisions. Even where local governments have acted in an unconstitutional way, the Court has been extremely reluctant to impose a remedy that disregards political boundaries established by the states. ${ }^{424}$

Although the principles of one person, one vote necessarily resulted in the judicially imposed redrawing of legislative district lines, ${ }^{425}$ the Court has been sensitive to the peculiar needs of local units of governments, permitting greater deviations from strict mathematical precision in order to respect political boundaries ${ }^{426}$ and local functional arrangements. ${ }^{427}$ It has recognized the desirability of encouraging local accommodations ${ }^{428}$ and bent over backwards to facilitate creation of special, limited function units of government by essentially immunizing them from basic voting rights principles. ${ }^{429}$ In short, the Court has continued to respect its early view ${ }^{430}$ that states should have considerable freedom in structuring their system of local governments. ${ }^{431}$

In Milliken $v$. Bradley ${ }^{432}$ the Court reversed a lower court's order for a school desegregation remedy beyond the boundary of Detroit. ${ }^{433}$ The district judge assumed that school district lines were not insurmountable obstacles to

424. See Milliken v. Bradley, 418 U.S. 717 (1974).

425. E.g., Reynolds v. Sims, 377 U.S. 533 (1964).

426. See Mahan v. Howell, 410 U.S. 315 (1973).

427. See Abate v. Mundt, 403 U.S. 182 (1971).

428. E.g., Town of Lockport v. Citizens for Community Action, 430 U.S. 259 (1977); Dusch v.

Davis, 387 U.S. 112 (1967); Sailors v. Board of Educ., 387 U.S. 105 (1967).

429. See Associated Enterprises, Inc. v. Toltec Watershed Improv. Dist., 410 U.S. 743 (1973);

Salyer Land Co. v. Tulare Water Dist., 410 U.S. 719 (1973). But see Hadley v. Junior College

Dist., 397 U.S. 50 (1970).

430. Hunter v. City of Pittsburgh, 207 U.S. 161 (1907).

431. See Town of Lockport, 430 U.S. at 271-72.

432. 418 U.S. 717 (1974).

433. The lower courts had found de jure segregation within the Detroit school system. Id. at $724-28,734-35$. This finding was not seriously challenged in the Supreme Court. Id. at 738 n. 18 , 748. 
federal judicial equitable power. ${ }^{434}$ In his view, effective desegregation required a remedy beyond the Detroit system; that view was influenced by the district judge's apparent perception that desegregation required, as a substantive matter, a certain degree of actual racial mixing. Without an interdistrict order, there simply were not sufficient white children to result in significant racial mixing. ${ }^{435}$

Chief Justice Burger's majority opinion emphasized that racial balance is not an affirmative constitutional guarantee. ${ }^{436}$ Moreover, local autonomy in education was an important value that federal courts could not ignore. In order to justify an interdistrict remedy, the Court required a showing either that the district lines were drawn deliberately on a racial basis or that the racial discrimination of a local district actually caused interdistrict segregation. ${ }^{437}$ Those narrow grounds for an interdistrict remedy circumscribe the

434. Id. at 741 .

435. Justice Marshall took this position in his dissenting opinion. Id. at 783-90, 803-05 (Marshall, J. dissenting).

436. Id. at 740-41. The majority opinion relied upon Swann v. Charlotte-Mecklenburg Bd. of Educ., 402 U.S. 1, 24 (1971).

437. 418 U.S. at 745. The decision in Milliken imposed a duty on plaintiff to show either intentional segregation in the structuring of districts or discriminatory acts of one district which had a causal relationship to segregation in an adjacent district. Id. Thus, plaintiff had the burden of showing, through demographic and other data, that there had been a racially discriminatory impact beyond the district in which the showing of deliberate segregation had been made.

In the earlier decision of Keyes v. School Dist. No. 1, 413 U.S. 189 (1973), the Court had established a very different burden of proof. Within a single district, a plaintiff need only show intentionally segregative acts within a meaningful portion of the district. That showing constitutes a prima facie case of reciprocal segregative effects beyond the area, but still within the district. Id. at 208. The school district then must show, to defeat a finding of liability, that these presumed reciprocal effects did not materialize. Id. at 204-05, 213. This could be proven if, for example, the area in which the segregative intent occurred was shown to be a "separate, identifiable and unrelated unit" of the district. Id. at 203, 205, 213 .

With respect to the finding of intent, once a plaintiff shows an intent to segregate in a significant portion of a single district, the Court will presume that de facto segregation in the rest of the district was not accidental, but arose from that same discriminatory intent. Id. at 208-10, 213 . That element in the finding of Keyes drew a stinging rebuke from Justice Rehnquist in dissent. He labeled that presumption as analogous to the doctrine of "taint" which was still to be found in some "primitive" legal systems. Id. at 257 (Rehnquist, J., dissenting).

Under the Keyes presumption formulation, the school district theoretically has an opportunity to disprove the presumption, but the burden of proof is virtually insurmountable. See, e.g., Columbus Bd. of Educ. v. Penick, 99 S. Ct. 2941, 2971 (1979); Dayton Bd. of Educ. v. Brinkman, 99 S. Ct. 2971, 2982 (1979) (Rehnquist, J., dissenting). The district must prove a negativenamely, that there was no discriminatory intent or that the segregation would have arisen in any case despite the actions of the school board. 413 U.S. at $211,213-14$.

In Milliken, neither of the Keyes presumptions was applied. The common sense basis for the presumption about intent-that a single school district was involved-did not exist. With respect to the reciprocal effect analysis, the Court concluded that deference to political boundaries of school districts was a matter of great importance. Presumably, using the Keyes reasoning, a political school district line created a separate, identical, and unrelated district, unless the plaintiffs could prove otherwise.

The dissenters in Milliken argued that the State of Michigan was implicated in the discriminatory behavior. 418 U.S. at 790-98 (Marshall, J., dissenting). For that reason, they concluded that the Keyes analysis was much more appropriate than the majority suggested. Id. at 793-98. 
Court's equitable authority where the structure of local governments is at stake.

The Milliken doctrine is consistent with the Court's refusal, in the land use area, to impose affirmative regional duties on municipalities. Because Milliken "was premised on a controlling principle governing the permissible scope of federal judicial power," ${ }^{438}$ it has broad application beyond the school desegregation context. It was not merely the consequence of a balancing process among competing equitable principles; rather, it "was based on basic limitations on the exercise of the equity power of the federal courts." 439 As such, Milliken's principles of interdistrict relief, even where racial discrimination against a municipality has been found, are presumably applicable in a land use context. ${ }^{400}$ The narrow range for interdistrict relief is further evidence of the Supreme Court's disinclination to impose regional duties or remedies on local units of government, whose authority and jurisdiction have been established under state law. ${ }^{441}$

\section{Standing}

The Court's reluctance to countenance sweeping remedies that transcend local boundaries, to narrow the range of permissible zoning purposes, or to develop substantive doctrines that establish regional obligations for local units of government is manifest in its restrictive interpretation of standing doctrine in the exclusionary zoning context.

Warth $v$. Seldin ${ }^{442}$ involved a broad systemic challenge to the zoning scheme of Penfield, a suburb of Rochester, New York. The plaintiffs, in what was obviously a major law reform lawsuit, have been described by a sympathetic commentator as having the "mutually supportive qualities of a troop deployment." ${ }_{433}$ They included individual nonresidents who alleged that the zoning

438. Hills v. Gautreaux, 425 U.S. 284, 294 n.11 (1976).

439. Id. at 294.

440. In Hills, the Supreme Court specifically noted that the Milliken analysis could not be confined to a school district setting. Id. at 294-95. Nevertheless, the Hills Court awarded a remedy which extended beyond the local unit of government.

The unanimous Court based the broader relief on a finding that the federal Department of Housing and Urban Development (HUD) was guilty of racially discriminatory actions. Id. at 289. HUD had areawide jurisdiction that extended beyond the city limits as did the Chicago Housing Authority (CHA), which had also been found guilty of racial discrimination. Id. at 286, 298.

Furthermore, HUD did not need local governmental approval for construction of low-cost housing in a suburb except in certain specified instances. Id. at 304 . The Court, therefore, felt no discomfort in ordering HUD to exercise authority it already had under governing federal law and in ordering the CHA to exercise similar authority granted by state law.

441. Where the geographical jurisdiction is so defined as to further racially discriminatory objectives, Milliken allows judicial rejection of state-drawn boundaries. See note 437 supra. For an example of racial boundary drawing, see United States v. Scotland Neck Bd. of Educ., 407 U.S. 484 (1972).

442. 422 U.S. $490(1975)$

443. Sager, supra note 291 , at 1376 n.9. 
practices of Penfield had the effect of excluding them from living in the community. ${ }^{44}$ Without deciding the merits, the Court held that none of the plaintiffs had standing. For the five-to-four majority, Justice Powell distinguished between two types of standing: constitutional and prudential. ${ }^{445}$ The constitutional doctrine of standing is a threshold inquiry mandated by the "case or controversy" requirement of Article III.446 In this sense, "standing imports justiciability," that is "whether the litigant is entitled to have the court decide the merits of the dispute or of particular issues." 447 The constitutional limitation, therefore, "determin[es] the power of the court to entertain the suit," 448 whether federal jurisdiction can be invoked by a given plaintiff who seeks the "exercise of the court's remedial powers on his behalf." 449

The prudential limitations on standing announced in Warth, "essentially matters of judicial self-governance,"450 are imposed because of the Court's concern about its legitimacy which stems from its unelective nature and the life tenure of its members. ${ }^{451}$ Justice Powell made it clear that the prudential limitations on standing allowed courts to shun "abstract questions of wide public significance" where "judicial intervention may be unnecessary to protect individual rights." ${ }^{452}$

In the factual context of Warth, the major example of a prudential limitation on standing was the requirement that a plaintiff assert his own legal rights and interests, not those of third parties. ${ }^{453}$ That disposed of the claims

444. Other plaintiffs included Rochester property owners and taxpayers who alleged that the exclusionary practices resulted in higher tax rates within the city, a builders' association which alleged that the exclusionary practices resulted in loss of profits and business opportunities on the part of its members, a nonprofit housing council which was interested in developing low and moderate cost housing, and Metro-Act, a citizens' action group which sought to alleviate the housing shortage in Monroe County. 422 U.S. at 493-517 passim. For a discussion of the standing requirements as applied to these plaintiffs, see The Supreme Court, 1974 Term, 89 HARv. L. Rev. 47 , 189-95 (1975).

445. Justice Powell first made this distinction in United States v. Richardson, 418 U.S. 166, 181 (1974) (Powell, J., concurring).

446. "The Judicial Power shall extend to all Cases, in Law and Equity, arising under this Constitution, the Laws of the United States, and Treaties . . . [and] to Controversies to which the United States shall be a Party . . ."U.S. Const. art. III, $\S 2$, cl. 1 .

447. 422 U.S. at 498.

448. Id.

449. Id. at 498-99.

450. Id, at 500 .

451. Justice Powell had earlier warned of this concern. "Relaxation of standing requirements is directly related to the expansion of judicial power .... We should be ever mindful of the contradictions that would arise if a democracy were to permit general oversight of the elected branches of government by a nonrepresentative, and in large measure insulated, judicial branch." United States v. Richardson, 418 U.S. 166, 188 (1974) (Powell, J., concurring) (footnotes omitted). See generally A. Bickel, The Least Dangerous Branch (1962). But see Wright, Professor Bickel, The Scholarly Tradition, and the Supreme Court, 84 Harv. L. REv. 769 (1971).

452. 422 U.S. at 500 .

453. Id. at 499. Justice Powell also wrote that " $[w]$ hen the asserted harm is a 'generalized grievance' shared in substantially equal measure by all or a large class of citizens, that harm alone normally does not warrant exercise of jurisdiction." Id. This is the traditional requirement that "a 
of residents of Penfield, who were asserting the rights of allegedly excluded nonresidents. ${ }^{454}$ One important feature of a prudentially-imposed standing rule is that it can be overturned by an explicit legislative judgment that the courts should take on the case. ${ }^{455}$ Provided the Court, out of self-restraint, declines to hear a case because of the absence of legislative authorization, it follows that the Court can adjudicate an issue when standing is statutorily conferred.

At least with respect to the prudential standing component of Warth, a remedy lies with the legislature. More serious from a plaintiff's perspective is the Article III component of Warth, which held that nonresidents did not satisfy the basic constitutional minimum to pass the "case or controversy" threshold. ${ }^{456}$ That decision, resting on the Constitution, is not so readily altered by legislative action.

Warth identified two components to the "injury in fact" that is necessary to achieve constitutional standing. ${ }^{457}$ First, a plaintiff must allege a "distinct and palpable injury to himself;" 458 that is, a nonresident plaintiff must allege "specific, concrete facts demonstrating that the challenged practices harm him."459 Second, the plaintiff must show that there is a "substantial probability" 460 that he will "personally . . . benefit in a tangible way from the court's intervention." 461 Thus, in addition to harm, a plaintiff must show that there is a causal relationship between the Court's action and some tangible personal benefit. ${ }^{\mathbf{4 6 2}}$

plaintiff must allege some particularized injury that sets him apart from the man on the street." Richardson, 418 U.S. at 194 (1974) (Powell, J., concurring) (footnote omitted). That prong of the Warth decision seems to have been somewhat undermined by the recent decision in Duke Power Co. v. Carolina Environmental Study Group, Inc., 438 U.S. 59 (1978), in which the Court declined to apply the limitation "to all cases as a matter of course." Id. at 80 . Where the constitutional standing requirements are met and "[w]here a party champions his own rights, ... the basic practical and prudential concerns underlying the standing doctrine are generally satisfied ..."Id. at 80-81.

454. 422 U.S. at 514.

455. Id. at 509. For an example of a broad interpretation of a statutory conferral of standing, see Trafficante v. Metropolitan Life Ins. Co., 409 U.S. 205 (1972) (allowing third party standing under Fair Housing Act). Accord, Gladstone, Realtors v. Village of Bellwood, 441 U.S. 91 (1979).

456. 422 U.S. at 502. The New Jersey Supreme Court's approach to standing, like its approach on the substantive issues, is strikingly at variance with federal standing doctrine. See Southern Burlington Cty. NAACP v. Township of Mt. Laurel, 67 N.J. 151, 159 n.3, 336 A.2d 713,717 n.3 (1975).

457. The Court in Warth did not mention the traditional requirement that a plaintiff's claim come within the zone of interest protected by the constitutional or statutory provision involved. For discussion of this requirement see Boston Stock Exch. v. State Tax Comm'n, 429 U.S. 318 , 320-2 1 n.3 (1977); Barlow v. Collins, 397 U.S. 159, 164-66 (1970); Association of Data Processing Serv. Orgs. Inc. v. Camp, 397 U.S. 150, 152-54 (1970); L. TRIBE, supra note 347, at $\$ 3-22$; Sager, supra note 291 , at $1377-81$.

458. 422 U.S. at 501.

459. Id. at 508 (emphasis in original)

460 . Id. at 504 .

461. Id. at 508 .

462. The causal nexus requirement was elaborated on in the subsequent case of Simon v. Eastern Ky. Welfare Rights Org., 426 U.S. 26, 38-39, 44-46 (1976). 
Despite Justice Powell's assertion that standing does not turn on the merits, ${ }^{483}$ he conceded that it often does depend on the "nature and source of the claim asserted." ${ }^{464}$ The dissenters perceived that the constricted view of causality in Warth must stem from hostility to judicial involvement in such matters of local political structure, which have significant socioeconomic overtones. ${ }^{465}$ That view is shared by those who observe that " $[t]$ he remedy-injury nexus ... reflects the Court's reluctance to decide abstract social issues or to determine complex claims of cause and effect." ${ }^{466}$

The Warth decision has come in for considerable criticism, ${ }^{467}$ with Professor Sager labeling the Warth causality rule "an analytical embarrassment," 468 and Professor Tribe calling the result "aberrational"469 and "harsh and bizarre." 470

Careful, and even casual, readers of Warth must be struck by the theme of judicial self-restraint that Justice Powell first introduced into the law of standing in his concurrence in United States $v$. Richardson. ${ }^{471}$ To the extent that matters of grave public policy are brought into federal court by an expansively defined law of standing, the courts are bound to come into increasing conflict with the political decisions of popularly elected officials. ${ }^{472}$ For Justice Powell, the intellectual heritage of Justice Frankfurter and Professor Bickel ${ }^{473}$ counsels caution before allowing judicial intrusion in broad political matters.

The prudential standing doctrine, with its emphasis on deference to legislatively conferred standing, conforms closely to the Powell view that the Court should enter a cooperative political dialogue with the legislative branch, imposing limits on its own authority but accepting expansion of its role at the behest of Congress.

The causality requirement in Warth, viewed sympathetically, may be an at-

463. 422 U.S. at 500 .

464. Id.

465. Id. at 518 (Douglas, J., dissenting); id. at 520 (Brennan, J., dissenting). The majority openly admitted its reluctance to interfere in the political process. See id. at $508 \mathrm{n} .18$ ("[Zoning laws] are ... subject to judicial review in a proper case. But citizens dissatisfied with provisions of such laws need not overlook the availability of the normal democratic process.").

466. Zoning Development, supra note 290 , at 1663 . According to that commentator, "[i]n the majority's view, to reach the merits of the alleged constitutional violation in Warth would be to invite judicial participation in a complicated reordering of perceived local decision making." Id. See also Sager, supra note 291 , at 1389 ("[T]he Court is reluctant to have the federal judiciary assume the prominent role in the process of land use planning which the adjudication of farreaching claims of zoning exclusion would require"); Zoning Development, supra, at 1663 n.159.

467. E.g., L. Tribe, supra note 347, at \$ 3-21; Note, Standing to Challenge Exclusionary Land Use Devices in Federal Courts after Warth v. Seldin, 29 STAN. L. Rev. 323, 345-49 (1977).

468. Sager, supra note 291 , at 1388 (footnote omitted).

469. L. TRIBE, supra note 347 , at 96 .

470. Id. at 97 .

471. 418 U.S. 166,180 (1974). See also note 451 supra.

472. 418 U.S. at 188 .

473. See, e.g., A. Bickel, The Supreme Court and the Idea of Progress (1970); Bickel, The Supreme Court, 1960 Term-Foreword: The Passive Virtues, 75 HARv. L. REv. 40 (1961). See also Blumstein, The Supreme Court's Jurisdiction-Reform Proposals, Discretionary Review, and Writ Dismissals, 26 VAND. L. REv. 895, 901-16 (1973); Wright, supra note 451. 
tempt to channel constitutional challenges into what Professor Sager has called the Marbury model ${ }^{47}$ - that is, constraining judicial review by limiting it to the personal rights of individual litigants. ${ }^{45}$ The classic justification for judicial review has been the notion that courts, almost against their will, are dragged into constitutional adjudication only as an incident of their core role of vindicating individual rights. A requirement that a judicial decree benefit a plaintiff in a tangible way is a reasonably faithful adaptation of the law of standing to the principles of Marbury-at least one version of Marbury. ${ }^{476}$

The problem in Warth is the "substantial probability" language and the almost tortured and speculative basis of the Court's analysis of the interests of nonresident plaintiffs. This is most glaring in an extended footnote in which Justice Powell attempted to rebut the causal relationship between a judicial invalidation of the zoning ordinances and the nonresident plaintiffs' potential to benefit from such a decree. ${ }^{477}$ After all, it does seem likely that if restrictive land use regulations are stricken, at least the filter down rationale of Oakwood at Madison ${ }^{478}$ would suggest expanded opportunities for low and moderate income persons. ${ }^{479}$

The basic question for the Powell analysis, however, is whether the invocation of the Court's authority is appropriate when only a structural change in the housing market will come about and the resulting benefit would be of a "statistical" rather than an "identifiable" variety. ${ }^{480}$ One can understand why a court seeking to uphold the Marbury model might well conclude that the broad systemic challenge represented by Warth should be narrowed so that the range of issues to be considered by a court can be more narrowly confined to those of more immediate benefit to identifiable individuals.

Nevertheless, even if one is understanding toward the Court's "bias against systemic zoning attacks," 481 one must conclude that Warth's standard ("sub-

474. Sager, supra note 291 , at 1377-81.

475. Marbury v. Madison, 5 U.S. (l Cranch) 137 (1803).

476. For a thorough discussion of the various possible interpretations of Marbury, see Van Alstyne, A Critical Guide to Marbury v. Madison, 1969 Duke L.J. 1

477. 422 U.S. at 506 n.16. See Zoning Development, supra note 290, at $1663 \mathrm{nn} .158$ \& 161.

478. Oakwood at Madison, Inc. v. Township of Madison, 72 N.J. 481, 513-14, 371 A.2d 1192, 1208 (1977). See notes $161 \& 163$ supra and accompanying text.

479. Compare the rigorous causality requirement in Warth with the more permissive standard in Duke Power Co. v. Carolina Environmental Study Group, Inc., 438 U.S. 59, 80-81 (1978). It was clear that a majority of the Duke Power Court wished to reach the merits of the claim, as was duly noted by Justice Rehnquist. Id. at 95 (Rehnquist, J., concurring in judgment).

480. These terms are derived from the medical services context. They describe the ability of society to cope with statistical lives-the lives lost through higher speed limits or lax safety requirements-more easily than it copes with identifiable lives-the balloonist lost at sea or the astronaut lost in space. See Fried, The Value of Life, 82 HARv. L. Rev. 1415 (1969); Havighurst \& Blumstein, Coping with Quality/Cost Trade-Offs in Medical Care: The Role of PSROs, 70 Nw. U. L. Rev. 6, 21 -23 (1975); Havighurst, Blumstein \& Bovbjerg, Strategies in Underwriting the Costs of Catastrophic Disease, 40 LAw \& Contemp. Prob., Autumn 1976, at 122, 140-45.

481. Sager, supra note 291 , at 1393 n.68. 
stantial probability" of achieving an ultimate benefit) is excessively stringent. ${ }^{482}$ The Court's rapid reformulation of that rule in subsequent decisions $^{483}$ suggests that Warth is best read as an interstitial decision, articulating for a majority the twin concepts of constitutional and prudential standing and introducing the causality concept as a component of constitutional standing. Arising in a land use context, Warth preceded the decision in Washington $v$. Davis, ${ }^{\mathbf{4 8 4}}$ which crystallized federal constitutional doctrine in reviewing local land use decisions. In this regard, perhaps it is worth more prominent attention that the majority treated the claim as one of economic discrimination. ${ }^{485}$ Although Justice Brennan's dissenting opinion treated the complaint as alleging purposeful racial discrimination, the majority consistently regarded the case as one involving at most purposeful exclusion of low and moderate income persons. ${ }^{486}$

Given the ambiguity in the contemporaneous development of substantive doctrine, ${ }^{487}$ Warth may best be seen as a holding action, barring broad systemic challenges until such time that substantive doctrine could be elaborated and clarified through an evolving consensus. Of course, there is ample room for criticism of that type of ruling, ${ }^{488}$ but it does conform to the ascendant majority's general deference to and faith in legislative processes, ${ }^{489}$ its somewhat romantic conviction that democratic processes will function fairly without judicial oversight, ${ }^{490}$ and its general aversion at ordering major institutional restructuring. ${ }^{491}$

That Warth's barrier to exclusionary zoning litigation was not insuperable was made manifest less than two years later, after the Washington ${ }^{\mathbf{4 9 2}}$ decision established the analytical framework for determining how racial discrimination was shown in a constitutional context. In the Arlington Heights ${ }^{493}$ case, the Court found standing for a nonresident plaintiff. ${ }^{494}$ There was a specific project involved, and so the focus of analysis was narrowed. The nonresident plaintiff lived twenty miles from Arlington Heights but worked in a factory

482. The standard also seems malleable and subject to the Court's perception of the merits of a complaint. See note 479 supra. Compare Simon v. Eastern Ky. Welfare Rights Org., 426 U.S. 26

(1976) with Duke Power Co. v. Carolina Environmental Study Group, Inc., 438 U.S. 59 (1978).

483. E.g., Duke Power Co. v. Carolina Environmental Study Group, Inc., 438 U.S. 59 (1978). See note 453 supra.

484. 426 U.S. 229 (1976).

485. 422 U.S. at 513 \& n.21; Zoning Development, supra note 290 , at 1664 n.162.

486. 422 U.S. at 493, 495, 496, 502, 507, 512-13 \& n.21; Sager, supra note 291, at 1376 n.8.

487. See Washington v. Davis, 426 U.S. 229, 244 n.12 (1976).

488. See, e.g., Sager, supra note 291, at 1390; Zoning Development, supra note 290, at 1663 n. 159 .

489. See Blumstein, supra note 153 , at 477 n.13.

490. E.g., Morris v. Gressette, 432 U.S. 491,506 n.23 (1977).

491. E.g., Rizzo v. Goode, 423 U.S. 362 (1976).

492. 426 U.S. 229 (1976). See text accompanying notes 343 \& 344 supra.

493. Village of Arlington Heights v. Metropolitan Hous. Dev. Corp., 429 U.S. 252 (1977).

494. Id. at 264 . 
there. He alleged that, if the project were built, he would be eligible to move there, closer to his job. ${ }^{495}$

The Court decided that the nonresident individual had standing because he would probably benefit if the project were built and if the Court granted relief the project would actually be built. This chain of causation is far from certain $^{496}$ and the standard seems less rigorously applied than in Warth ${ }^{497}$ Moreover, with respect to the nonprofit housing developer, the Court seemed to apply not a standard of "substantial probability" but a somewhat more lenient "like[lihood]" criterion. ${ }^{498}$

The existence of a specific project and the decision in Washington that set out an analytical framework made the Arlington Heights situation more containable from the perspective of Justice Powell. Applying the intentional discrimination test of Washington, the Court found no substantive violation. ${ }^{499}$ The application of Washington to the land use context makes it seem more plausible that Warth was indeed a holding action. After the anlysis in Arlington Heights, it would appear difficult if not impossible as a practical matter to make out a claim of racial discrimination in zoning, especially using a "systemic" theory. However, if a community is sufficiently blatant in its racist approach, it is likely to be manifest in one or a set of identifiable projects. In such a case, a plaintiff need not be excessively intimidated by the more outlandish speculations of Warth. Given Arlington Heights and the clarification of substantive doctrine, lawsuits in the "proper" mold will not likely face the same type of hostility that the plaintiffs in Warth endured. Systemic reformers, on the other hand, seeking to undermine the purpose approach of Washington and Arlington Heights by promoting an impact rationale, ${ }^{500}$ are likely to face resistance, if not on standing grounds then on the merits. Those efforts are likely to continue and just as likely to breed frustration. ${ }^{501}$

\section{Popular Referenda}

Efforts to invoke Supreme Court assistance in limiting the procedures by which local land use decisions are made have been as unsuccessful as other similar reformist initiatives have been. The Court is apparently satisfied with a

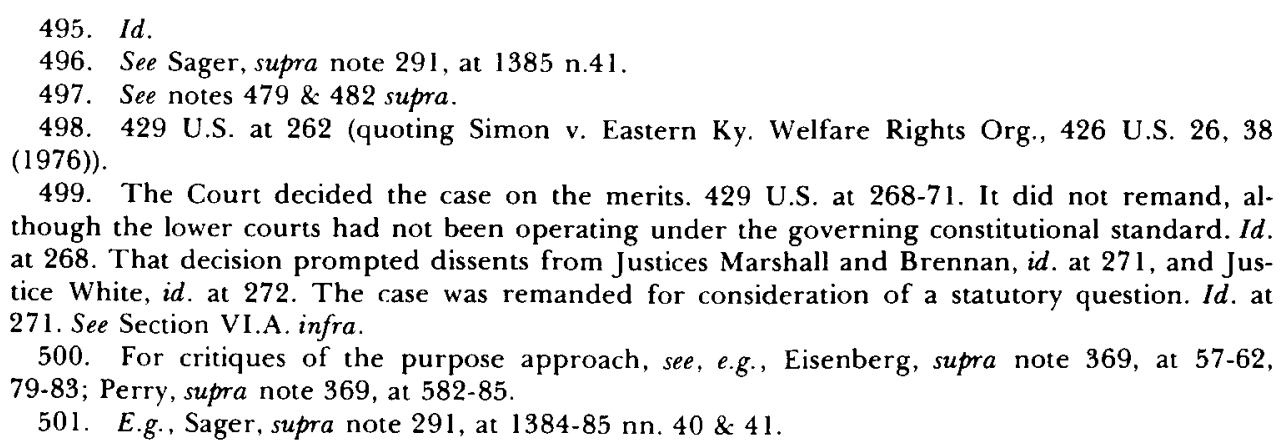

499. The Court decided the case on the merits. 429 U.S. at 268-71. It did not remand, although the lower courts had not been operating under the governing constitutional standard. Id. at 268. That decision prompted dissents from Justices Marshall and Brennan, $i d$. at 271, and Justice White, id. at 272. The case was remanded for consideration of a statutory question. $I d$. at 271. See Section VI.A. infra.

500. For critiques of the purpose approach, see, e.g., Eisenberg, supra note 369, at 57-62, 79-83; Perry, supra note 369 , at 582-85.

501. E.g., Sager, supra note 291, at 1384-85 nn. 40 \& 41. 
Euclid-Nectow style of substantive review for arbitrariness after the fact; ${ }^{502}$ it has declined to impose standards of procedural or structural due process on local land use decision making, ${ }^{503}$ absent a finding of purposeful or facial racial discrimination. ${ }^{504}$

In City of Eastlake v. Forest City Enterprises, Inc. ${ }^{505}$ the Court upheld the validity of a city charter amendment that required popular approval of any zoning changes approved by the city council. ${ }^{506}$ For the six-to-three majority, Chief Justice Burger rejected the twin claims of impermissible ${ }^{507}$ and standardless ${ }^{508}$ delegation of legislative authority. By framing the issue in that way, the Chief Justice was able to avoid dealing with "a serious issue of democratic theory," 509 which was in the case if sympathetically viewed.

The Court's analysis of the Eastlake claims was disarmingly simple. The majority dismissed, almost out of hand, the contention that "a zoning referendum involves a delegation of legislative power." 510 The reason, straightforward enough, was that a referendum is a "reservation" of power by the people, from whom "all power derives," 11 and cannot properly be "characterized as a delegation of [legislative] power" at all. 512

502. City of Eastlake v. Forest City Enterprises, Inc., 426 U.S. 668, 677 (1976).

503. Id. at 679. For a discussion of the structural due process approach, see Sager, supra note 291, at 1411-12. See generally L. TRIBE, supra note 347, at $\$ \$ 17-1$ to -3 ; Linde, Due Process of Law Making, 55 Neb. L. Rev. 197 (1976); Tribe, Structural Due Process, 10 Harv. C.R.-C.L.L. Rev. 269 (1975).

504. See Village of Arlington Heights v. Metropolitan Hous. Dev. Corp., 429 U.S. 252 (1977); Washington v. Davis, 426 U.S. 229 (1976). See generally Mandelker, supra note 293; Wright, supra note 299 .

505. 426 U.S. 668 (1976).

506. For critics of the decision, "Eastlake raises the spector of a popular veto of any municipal effort to accommodate unpopular use of land through relaxation of zoning restraints and, more particularly, of the chronic electoral exclusion of proposed lower income housing construction." Sager, supra note 291, at 1402. Since "[p]rovisions for referendums demonstrate devotion to democracy, not to bias, discrimination, or prejudice," James v. Valtierra, 402 U.S. 137, 141 (1971), the critics of using this form of popular democracy apparently are concerned with the reduced role for political compromise and judicial review. The decision is seen as a "disturbing portent" because it is a "setback in the fight against exclusionary zoning." Hogue, supra note 291, at 42.

In fact, the Court treated the Eastlake referendum provision as a property rights lawsuit, not an exclusionary zoning case. Two of the three dissenters in the public housing referendum case, James v. Valtierra, supra, (Justices Marshall and Blackmun) were in the Eastlake majority and Justice Powell, who dissented in Eastlake, made clear his concern with the "disquieting opportunities for local government bodies to bypass normal protective procedures for resolving issues affecting individual rights." 426 U.S. at 680 . The right of a landowner, who seeks a change in the land use category applied to his property, to a "fair procedure" to protect his "interest in making legitimate use of his property" was also the basis of Justice Stevens' dissent. Id. at 682 . Had the plaintiffs been able to marry the property rights component of their complaint with the interests of the potentially excluded newcomers-something done by the Pennsylvania Supreme Court, see Section III, A. supra-they might well have swung the critical votes of Justices Marshall and Blackmun.

507. 426 U.S. at 672 .

508. Id. at 675 .

509. Sager, supra note 291 , at 1403 .

510.426 U.S. at 672 .

511. Id.

512. Id 
On the question of standards, the claim was that "no mechanism existed nor indeed could exist, to assure that the voters would act rationally in passing upon a proposed zoning change." ${ }^{13}$ The Court's short answer to that proposition was that the need for standards existed only where legislative authority was delegated by the legislature to a regulatory body, not where it was "reserved by the people to themselves." 514 The reason for requiring standards where authority is delegated to a regulatory body is that it is "not directly responsible to the people." 515 Consequently, the requirement of "discernible standards" is a means of ensuring accountability, providing a mechanism for measuring an agency's actions "for its fidelity to the legislative will."516 When the original source of authority retains that power for itself, there is no similar need to build in a method for checking on accountability.

The Eastlake analysis is not wrong as far as it goes, but its simplicity is deceptive and ultimately unsatisfying because the Court has not come to grips with the core issue in the case-whether, as a matter of federal constitutional law, the decision on rezoning a single parcel of land can be committed to a political (i.e., legislative) process. ${ }^{517}$ The Court avoided grappling with that basic issue by relying on the Ohio Supreme Court's characterization of rezoning as a legislative matter under state law. ${ }^{518}$ That characterization is important under Ohio law, ${ }^{519}$ as it is in many states $^{520}$ because the state courts have distinguished between legislative matters, which are subject to the referendum process, and administrative matters, which are not. ${ }^{521}$

Yet, the characterization of rezoning as a legislative action effectively ends the analysis since traditionally notice and hearing and other procedural protections are required only in an administrative context. ${ }^{522}$ In short, if the claims of the plaintiff are to be listened to sympathetically, the Court must be willing to determine, as a constitutional matter, ${ }^{523}$ whether the nature of the

513. Id. at 675 .

514. Id.

515. Id.

516. Id.

517. Cf. Sager, supra note 291, at 1403 (The fundamental issue is "whether there are limits to the range of legislative functions which legitimately can be discharged by the electorate as opposed to deliberative governmental bodies") (footnotes omitted). See also id. at $1403 \mathrm{n} .104$.

518. 426 U.S. at 673 .

519. Ohio cases which draw that legislative/administrative distinction include Forest City Enterprises, Inc. v. City of Eastlake, 41 Ohio St. 2d 187, 324 N.E.2d 740 (1975) and Berg v. City of Struthers, 176 Ohio St. 146, 198 N.E.2d 48 (1964).

520. See Zoning Development, supra note 290 , at 1529 n.131 (cases collected).

521. See generally id. at 1528-36.

522. Id. at 1530 .

523. One commentator has gone so far as to assert that "whether rezoning a specific parcel of land is an administrative decision which therefore requires due process safeguards ... is a matter of constitutional, not state, law." Id. at 1540. This point is argued by Justice Stevens in his dissenting opinion in Eastlake, 426 U.S. at 686 . Justice Stevens, however, found state law controlling when writing the majority opinion in the contemporaneous decision in Bishop v. Wood, 426 U.S. 
governmental action involved is susceptible to determination by a process that is political-i.e., not subject to procedural safeguards nor to reliance on neutrally and fairly applied standards that govern outcomes. Moreover, as Professor Sager has argued, there is the further question whether the type of political decision used by Eastlake-namely, the referendum rather than a representative, deliberative political institution-is an appropriate form of political device that can be used in the rezoning situation. ${ }^{524}$

The Eastlake majority opinion failed to recognize that the state courts have wrestled with the distinction between legislative and administrative functions in the zoning process. ${ }^{525}$ These courts have noted the difference between the process of establishing general zoning policies in the comprehensive plan and in the general zoning ordinance on the one hand and in the fine-tuning of the land use scheme through individual lot rezoning on the other. ${ }^{526}$ The body performing the task is not the critical variable; instead, the nature of the function is determinative. ${ }^{527}$ These courts have concluded that a rezoning amendment is much closer in functional terms to a variance than to the initial adoption of a comprehensive zoning ordinance.

Accordingly, in the well known Fasano case, ${ }^{528}$ the Oregon Supreme Court

341 (1976), in which the sufficiency of a claim of "property interest" was "decided by reference to state law." Id. at 344. In Bishop Justice Stevens disparaged Justice Brennan's "innovative suggestion that we develop a federal common law of property rights ..." Id. at 349 n.14.

In contrast to his position on the source of the definition of property in the procedural due process context, Justice Stevens has viewed the "liberty" described in the fourteenth amendment as a term defined by federal constitutional norms. See Meachum v. Fano, 427 U.S. 215,233 (1976) (Stevens, J., dissenting). This dichotomy-between the source of property entitlements and liberty interests-seems to command a majority of the Court, despite some earlier indications to the contrary in Paul v. Davis, 424 U.S. 693 (1976). See Smith v. Organization of Foster Families, 431 U.S. 816 (1977); Ingraham v. Wright, 430 U.S. 651 (1977).

Since, presumably, a property right is at stake in Eastlake, the earlier distinction drawn in the procedural due process context poses a problem for the Stevens position in Eastlake. Perhaps the Stevens and Powell dissents in Eastlake suggest a possible rethinking of the rigid rule that defines property rights entirely by reference to state law. But see Greenholtz v. Inmates of Nebraska Penal and Correctional Complex, 99 S. Ct. 2100 (1979); Bishop v. Wood, 426 U.S. 341 (1976). See also Blumstein, supra note 369 , at $241-46 \mathrm{nn} .50,55,63,64,70,78,79 \& 81$.

524. Sager, supra note 291 , at 1402-23.

525. Justice Steven' Eastlake dissent, however, noted the state court efforts. 426 U.S. at 683.

526. E.g., Fasano v. Board of County Comm'rs, 264 Ore. 574, 507 P.2d 23 (1973); Fleming v. City of Tacoma, 81 Wash.2d 292, 502 P.2d 327 (1972). See generally Zoning Development, supra note 290 , at $1508-13$.

527. Contra, Berg v. City of Struthers, 176 Ohio St. 146, 198 N.E.2d 48 (1964); State ex. rel. Hunzicker v. Pulliam, 168 Okla. 632, 37 P.2d 417 (1934). See Zoning Development, supra note 290, at 1509. An overly formalistic approach, one that views the nature of the decision making body as determinative, is "inappropriate because it permits the availability of procedural rights to turn upon the legislative allocation of zoning power among city councils, zoning boards, and other governmental entities-an allocation guided by considerations of administrability and political expediency rather than by the functional interests underlying due process." Id. at 1510 (footnote omitted). See also Ward v. Village of Skokie, 26 Ill. 2d 415, 424-25, 186 N.E.2d 529, 534 (1962) (Klingbiel, J., specially concurring) ("[B]asic constitutional protections can readily be circumvented by the simple expedient of placing quasi-judicial functions in a legislative body").

528. Fasano v. Board of County Comm'rs, 264 Ore. 574, 507 P.2d 23 (1973). 
held that rezoning decisions would be reviewed more strictly than legislative actions because the nature of the rezoning process necessitates more of the procedural safeguards of an adjudicative process in order to assure fairness. ${ }^{529}$ Similarly, the Michigan Supreme Court has held that a zone change is not subject to a referendum because that process can be used only with respect to legislative acts, whereas rezoning was "in substance an administrative, not legislative act." $\$ 30$ While other state courts might treat these matters differently, ${ }^{531}$ the point is that they have acknowledged that a difference exists between acts that are functionally legislative and those that are functionally administrative or adjudicative. These distinctions are important because they determine the propriety of using a political process and of deferring to the outcome of those decisions.

Sympathetically viewed, the plaintiff's complaint in Eastlake was that the rezoning process had the functional elements of an administrative or adjudicative proceeding and, therefore, use of the political decision making mode was constitutionally inappropriate. The risk of abuse and unfair treatment was excessive, and procedural protections were necessary. ${ }^{532}$ At a minimum, pursuing the Sager argument, a more structured political forum was required, where a legislative body could conduct fact-finding hearings, accept evidence, hear the interested parties, and make an informed, albeit political, decision based on the data it assembled..$^{53}$

The Court's response was to ignore these issues by taking as given the Ohio Supreme Court's characterization of the process as "legislative in nature." ${ }^{\text {534 }}$ Presumably, the Court is unwilling to determine, by functional analysis, the nature of different facets of the zoning process. That would conform to its general unwillingness to intervene in the area and its overall deference to state courts to define as a state law matter concepts that have clear constitutional significance. ${ }^{535}$ Perhaps the closest parallel is the Court's persistent insistence that the term "property" as used in the Fourteenth Amendment be defined as a matter of state law in procedural due process cases.536 Apparently, the Court is similiarly inclined to allow states to determine what is legislative by reference to principles of state law. In Eastlake it declined an opportunity

529. Id. at 587-88, 507 P.2d at 29-30.

530. E.g., West v. City of Portage, 392 Mich. 458, 461, 221 N.W.2d 303, 304 (1974).

531. E.g. San Diego Bldg. Contractors v. City Council, 13 Cal. 3d 205, 529 P.2d 570, 118 Cal. Rptr. 146 (1974), appeal dismissed, 427 U.S. 901 (1976).

532. Accord, 426 U.S. at 680 (Powell, J., dissenting); id. at 694 (Stevens, J., dissenting).

533. Sager, supra 291, at 1402-23.

534. 426 U.S. at 673.

535. See note 523 supra. See also Blumstein, supra note 369 , at 241-46.

536. See, e.g., Greenholtz v. Inmates of Nebraska Penal and Correctional Complex, $99 \mathrm{~S} . \mathrm{Ct}$. 2100 (1979); Bishop v. Wood, 426 U.S. 341, 344 (1976) ("[T]he sufficiency of the claim of entitlement must be decided by reference to state law"). See generally Blumstein, supra note 369 , at $241-42$. 
to develop federal constitutional principles for classifying functions as legislative or administrative ${ }^{537}$ in nature.

537. The Eastlake opinion considered the Court's earlier decisions in Eubank v. City of Richmond, 226 U.S. 137 (1912), Thomas Cusack Co. v. City of Chicago, 242 U.S. 526 (1917), and Washington ex rel. Seattle Title Trust Co. v. Roberge, 278 U.S. 116 (1928). In Eubank the Court held invalid a city ordinance that allowed owners of two-thirds of the property abutting any block to establish building setback lines. In Cusack the Court upheld a provision that permitted neighboring property owners to waive a billboard ban. In Roberge the Court held invalid an ordinance that permitted old-age homes in a residential zone but only with the written approval of the owners of two-thirds of the property within 400 feet of the building

The Chief Justice distinguished Cusack on the ground that "[s]ince the property owners could simply waive an otherwise applicable legislative limitation, the Court in Cusack determined that the provision did not delegate legislative power at all." 426 U.S. at $677-78$ n.12. With regard to Eubank and Roberge, he observed that they did not involve a referendum procedure but rather a "standardless delegation of power to a limited group of property owners . . ." Id. at 678. That is, unlike the reservation of power to the people in Eastlake's referendum, Eubank and Roberge involved delegation by the legislature "to a narrow segment of the community, not to the people at large." Id. at 677 (emphasis in original).

Eubank and Roberge can be understood in two different ways. First, the Court may have implicitly concluded that establishing setbacks or approving old-age homes was an administrative decision. Thus, the absence of "discernible standards" would be fatal. Cusack could be reconciled with these cases on that reading by concluding that waiver of the ban of billboards was a political judgment. The legislature had defined the entitlement in favor of the neighborhood, and, at their discretion, the beneficiaries were entitled to show their magnanimity by conferring that benefit on the billboard owner. It is not self-evident why the decision in Cusack should be characterized as political while the others should be deemed administrative, but that distinction, which would harmonize the cases, is consistent with the delegation/non-delegation language of the Eastlake majority.

A second way of viewing the Eubank-Cusack-Roberge trilogy would be to characterize them all as involving political decisions. The delegation language, on that reading, did not mean delegation of legislative authority to an administrative entity but was used in the sense that state legislatures delegate legislative authority to city councils, which exercise delegated (but clearly legislative) power.

On that reading the delegation issue in Eastlake becomes very different. That interpretation of the early cases indicates that they should be given meaning in a modern context by reference to voter qualification cases such as Kramer v. Union Free School Dist., 395 U.S. 621 (1969). See text accompanying notes 389-421 supra. Thus, Eubank and Roberge would be explained as holding that voting on setbacks for a block or on the permissibility of an old-age home could not be confined to property owners in the immediate neighborhood. That is, other voters had a strong interest in those decisions, and committing the decisions to the narrow constituency was unconstitutional. Cusack would then be harmonized by concluding that property owners in the immediate block were primarily affected by the existence of a billboard, and they could properly be given authority to vote on a waiver. See Associated Enterprises, Inc. v. Toltec Watershed Improv. Dist., 410 U.S. 743 (1973); Salyer Land Co. v. Tulare Lake Basin Water Storage Dist., 410 U.S. 719 (1973).

Viewed in a voting rights context, Eubank-Cusack-Roberge suggest that the proper issue in Eastlake was the constituency formation question posed by Justice Stern's concurrence in the Ohio Supreme Court: whether it is legitimate to allow everyone in a large city to vote on rezoning a corner gasoline station. Forest City Enterprises, Inc. v. City of Eastlake, 41 Ohio St. 2d 187, 199-200, 324 N.E.2d 740, 748-49 (1975) (Stern, J., concurring). That is a question never answered in the voting qualification cases-whether the franchise has been extended to an excessively broad constituency. See Ellickson, supra note 9, at 404-05 and nn.46-47. That line of cases only dealt with challenges to narrowly drawn voting qualifications. However, seen as a voting qualification case, Eastlake raises the novel issue of an arguably overinclusive class of voters. The Court's "consciously narrow decision," Zoning Development, supra note 290, at 1536, in Eastlake did not touch on that potentially interesting question. 
The Eastlake decision leaves unanswered the question whether any "limits exist upon the use of initiatives or referenda to decide even indisputably administrative issues." ${ }^{38}$ The Chief Justice quoted a passage from a local government law treatise to the effect that " $[t]$ he power of initiative or referendum may be reserved or conferred 'with respect to any matter, legislative or administrative, within the realm of local affairs . . ."539 He noted that under Ohio law only land use changes approved by the Council "when acting in a legislative capacity were subject to the referendum process." 540 Consequently, hardship variances, which were administrative under state law, would not be subject to the referendum process. ${ }^{541}$

That is an interesting conclusion about the functioning of Ohio law, but it is not a definitive answer to the question in a state that chose to submit hardship variance decisions to a popular voting process. Because the Eastlake opinion relies exclusively on state court characterization of a procedure as legislative or administrative, a strict reading of the case would suggest that use of an initiative or referendum in such circumstances would violate no federal constitutional rights even though no evidence would have been taken, no hearing provided, no impartial decision making involved, and no criteria articulated.$^{\mathbf{5 4 2}}$ One commentator has concluded that "[s]uch an expansive reading . . . is unwarranted," ${ }^{43}$ but nothing in the Eastlake decision itself is reassuring or conclusive on the matter. ${ }^{544}$

538. Zoning Develotment, supra note 290, at 1539.

539. 426 U.S. at 674 n.9 (quoting 5 E. McQuillis, supra note 2, at $\S 16.54$ ).

540. 426 U.S. at 674 n.9 (emphasis in original).

541. Id.

542. See Zoning Development, supra note 290, at 1539.

543. Id.

544. Id. That commentary draws the following conclusion:

"If a clearly administrative decision involving protected property interests were submitted to popular vote, the Court would have strong reason to hold the decisionmaking procedure unconstitutional. It would be impossible to convene the electorate to hold hearings prior to the election; the interests served by due process would be unfulfilled by either a hearing before the city council or a 'hearing' in the political arena; the voter decision could not comply with either the requirement of impartial decisionmaking or the insistence upon a reasoned decision using articulable standards." Id. at 1540 n. 197 (citation omitted). For further discussion on the compatibility of procedural due process and the popular vote, see id. at 1525-28, 1530-34.

The Court's decision in Ingraham v. Wright, 430 U.S. 651 (1977), suggests an alternative analytical approach for reconciling the concepts of due process and popular voting. In Ingraham, the Court permitted a potential state law damage action to serve as an adequate alternative to hearing or notice. Ingraham involved a case of corporal punishment meted out by public school personnel. The Court conceded that a liberty interest was being infringed, but it declined to impose traditional due process standards of hearing and notice because of the existence of a state court remedy for excessive infliction of physical harm. Building on the Ingraham concept, the Court could conclude that the existence of a public referendum (which has received judicial endorsement, James v. Valtierra, 402 U.S. 137 (1971)), is an adequate process or an acceptable alternative to the traditional due process criteria. At present, Ingraham stands alone as an analytical mode of determining what process is sufficient. See generally Mathews v. Eldridge, 424 U.S. 319 (1976). Whether Ingraham could or would be expanded in the manner suggested is far from certain at this point. 


\section{Limits on Governmental Power to Restrict Private Use of Property}

In upholding the comprehensive zoning scheme in Euclid against a facial challenge, the Supreme Court articulated two principles of limitation: (1) specific applications of generally valid zoning measures could be arbitrary and, therefore, invalid; and (2) at some point, local governmental authority over zoning might have to yield to broader regional interests. ${ }^{545}$ The Supreme Court's unwillingness to develop the regionalism language has already been discussed. ${ }^{546}$ It is now appropriate to consider the Court's treatment of arguably excessive or unfair regulation of individual parcels of land.

The fundamental problems are to identify the permissible scope of governmental regulatory authority and under what circumstances and in what amounts government must compensate private landowners when governmental action infringes on their property interests. The task is made more difficult by the presence of two seemingly distinct sources of authority for governmental action-the police power and the eminent domain power; over time, these ostensibly clear distinctions have become blurred through judicial interpretation. ${ }^{547}$

Traditionally, under a police power analysis, the remedy for governmental overreaching has been declaratory and injunctive relief-a declaration that a challenged law, as applied, violates economic substantive due process and an injunction against its enforcement. ${ }^{548}$ Damages have not been awarded. ${ }^{549}$ Under the eminent domain power, the Fifth Amendment ${ }^{550}$ requires that "just compensation" be paid when "private property" is "taken" by government "for public use." 551 Although these two sources of authority seem distinct, ambiguity arises for at least three separate reasons.

545. See text accompanying notes 8-11 supra.

546. See Section V.B. supra.

547. See generally F. Bosselman, D. Callies \& J. Banta, supra note 10; Berger, The Accommodation Power in Land Use Controversies: A Reply to Professor Costonis, 76 Colum. L. Rev. 799 (1976); Costonis, The Disparity Issue: A Context for the Grand Central Terminal Decision, 91 HaRv. L. REv. 402 (1977) [hereinafter cited as The Disparity Issue]; Costonis, "Fair" Compensation and the Accommodation Power: Antidotes for the Taking Impasse in Land Use Controls, 75 Colum. L. Rev. 1201 (1975). [hereinafter cited as "Fair" Compensation].

548. See The Disparity Issue, supra note 547, at 403-05; "Fair" Compensation, supra note 547, at 1033-34. See also Penn Central Transp. Co. v. City of New York, 42 N.Y.2d 324. 366 N.E.2d 1271, 397 N.Y.S.2d 914 (1977), aff'd, 438 U.S. 104 (1978).

549. See Ellickson, supra note 9, at 490-93. Professor Ellickson has described this as " $[\mathrm{t}]$ he most pervasive judicial error in American land-development law." Id. at 490 . See also HFH, Ltd. v. Superior Court, 15 Cal.3d 508, 542 P.2d 237, 125 Cal. Rptr. 365 (1975), cert. denied, 425 U.S. 904 (1976); Fred F. French Investing Co. v. City of New York, 39 N.Y.2d 587, 350 N.E.2d 381, 385 N.Y.S.2d 5 (1976), appeal dismissed, 429 U.S. 990 (1976).

550. The eminent domain component of the fifth amendment applies to the states by virtue of its incorporation under the fourteenth amendment. Penn Central Transp. Co. v. New York City, 438 U.S. 104, 122 (1978); id. at 141 n.3 (Rehnquist, J., dissenting).

551. The fifth amendment reads in part: "nor shall private property be taken for public use, without just compensation." U.S. Const., amend. V. 
First, increasingly the Supreme Court has eschewed judicial intervention under the economic substantive due process umbrella. ${ }^{52}$ The Euclid decision held that governmental regulation of land use was permissible, even if the value of the property was thereby diminished. When acting validly under the police power, government incurred no obligation to compensate the landowner for the decrease in value. Euclid allowed for individual challenges to generally valid zoning measures, but it noted that "[i]f the validity of the legislative classification for zoning purposes be fairly debatable, the legislative judgment must be allowed to control." ${ }^{53}$ Provided that the zoning exclusions "bear[] a rational relation to the health and safety of the community," 554 they are valid.

In the subsequent Nectow case, ${ }^{555}$ a unanimous Court held a zoning ordinance invalid under Euclid. Using an arbitrariness standard, Justice Sutherland concluded that the ordinance as applied was not reasonably related to police power purposes, relying on a factual finding by a master that the land use restriction would not benefit the residents of the relevant area. ${ }^{556}$

Taken together, Euclid and Nectow have been extremely influential in building a framework for analyzing land use regulations. When they were decided, an economic substantive due process mode was compatible with existing doctrine in related police power areas. ${ }^{557} \mathrm{~A}$ decade after Nectow, however, the Court steered an entirely different course in the economic substantive due process field, ${ }^{558}$ virtually withdrawing federal constitutional oversight of state economic regulation on substantive due process grounds. ${ }^{559}$ At the same time, for about thirty-five years the Court declined to hear another zoning case, ${ }^{560}$ thereby leaving state courts to develop substantive due

552. E.g., Usery v. Turner Elkhorn Mining Co., 428 U.S. I (1976); Ferguson v. Skrupa, 372 U.S. 726 (1963).

553. Village of Euclid v. Ambler Realty Co., 272 U.S. 365, 388 (1926).

554. Id. at 391 .

555. Nectow v. City of Cambridge, 277 U.S. 183 (1928).

556. Id. at 188 .

557. Justice Peckham, for instance, wrote in Lochner:

It must, of course, be conceded that there is a limit to the valid exercise of the police power by the State .... Otherwise the Fourteenth Amendment would have no efficacy and the legislatures of the States would have unbounded power, and it would be enough to say that any piece of legislation was enacted to conserve the morals, the health or the safety of the people; such legislation would be valid, .. m matter how absolutely without foundation the claim might be. The claim of the police power would be a mere pretext

Lochner v. New York, 198 U.S. 45, 56 (1905).

558. E.g., West Coast Hotel Co. v. Parrish, 300 U.S. 379 (1937); Nebbia v. New York, 291 U.S. 502 (1934).

559. E.g., Usery v. Turner Elkhorn Mining Co., 428 U.S. 1 (1976); North Dakota Bd. of Pharmacy v. Snyder's Drug Stores, 414 U.S. 156 (1973); Ferguson v. Skrupa, 372 U.S. 726 (1963).

560. In 1974 the Court decided Village of Belle Terre v. Boraas, 416 U.S. 1 (1974). Goldblatt v. Town of Hempstead, 369 U.S. 590 (1962), was technically a regulatory case, not a zoning ques- 
process doctrine in a land use context that was grossly inconsistent with the emerging federal constitutional doctrine of economic substantive due process. In a modern context, outside the land use area, a decision such as Nectow would likely be considered a dispensable relic of the activist economic substantive due process era. ${ }^{561}$ Since the Court remained aloof from land use controversies for so long, it allowed state court evolution of land use doctrine, in reliance on Euclid-Nectow, that no longer comported with governing constitutional norms in the context of other forms of governmental regulation of private economic interests.

A consequence of the "fairly debatable" standard of Euclid, especially as influenced by later thinking on economic substantive due process, was expanded use of the police power by local governments in the land use context. $^{562}$ This was a particularly attractive option for local government because a valid police regulation-one that reasonably promoted a legitimate public purpose-allowed public restriction of private land use without compensation. As a result, the stakes for both government and private landowners were extremely high; if a regulatory measure were proper under the police power, no compensation whatever was necessary. If government chose to use the more complicated eminent domain power, it must compensate the property owner for the taking according to the property's "highest and best use," a standard that could be quite expensive for government. ${ }^{563}$

The disparity in treatment of landowners under the police and eminent domain powers would not be as significant if the Nectow style of relief under economic substantive due process had remained as strong as a restraint on governmental authority as earlier. But the increasingly permissive judicial attitude toward public regulation ${ }^{564}$ created a strong incentive for landowners to characterize excessive or unreasonable governmental restrictions as "takings" under the eminent domain power. ${ }^{565}$ The labeling of arbitrary regulatory ac-

tion. The Court has heard inverse condemnation cases for intrusion of air space. See Griggs v. Allegheny County, 369 U.S. 84 (1962); United States v. Causby, 328 U.S. 256 (1946).

561. This might be done in the manner of Justice Douglas, who, in overruling an earlier decision, said, "The Liggett case, being a derelict in the stream of the law, is hereby overruled." North Dakota Bd. of Pharmacy v. Snyder's Drug Stores, 414 U.S. 156, 167 (1973). Cf. New Orleans v. Dukes, 427 U.S. 297 (1976) (overruling Morey v. Doud, 354 U.S. 457 (1957), which had been the only exception made by the Warren Court in its usual deference to legislative economic regulation).

562. See Associated Home Builders v. City of Livermore, 18 Cal.2d 582, 607, 557 P.2d 473, 483, 135 Cal. Rptr. 41, 51 (1976).

563. See generally Berger, supra note 547; The Disparity Issue, supra note 547, at 411-12; "Fair" Compensation, supra note 547, at 1038-45.

564. E.g. Associated Home Builders v. City of Walnut Creek, 4 Cal.3d 633, 484 P.2d 606, 94 Cal. Rptr. 630 (1971), appeal dismissed, 404 U.S. 878 (1971); Just v. Marinette County, 56 Wis. 2d 7. 201 N.W. 2d 761 (1972).

565. E.g., Arastra Ltd. Partnership v. City of Palo Alto, 401 F. Supp. 962, (N.D. Cal. 1975), vacated per stipulation, 417 F. Supp. 1125 (N.D. Cal. 1976); HFH, Ltd. v. Superior Court, 15 Cal. 3d 508, 542 P.2d 237, 125 Cal. Rptr. 365 (1975), cert. denied, 425 U.S. 904 (1975); Fred F. 
tion as a "taking" is the second source of the blurring of the police and eminent domain powers. ${ }^{566}$

The blurring of the two concepts was made easier doctrinally by two things. One was the concept of inverse condemnation. ${ }^{567}$ That arose when government effectively appropriated private property for public use. but sought to avoid paying just compensation. The existence of situations where private property was taken for a public use but where government declined to acknowledge the need for compensation allowed for the evolution of an initially narrow doctrine of inverse condemnation that, in turn, provided a vehicle for doctrinal expansion to cover situations of overregulation.

The doctrinal expansion of inverse condemnation, which led to the "premise that the police and eminent domain powers are correlatives," 568 was, in turn, facilitated by what Professor Costonis has labeled Justice Holmes' "aphorism" ${ }^{569}$ in Pennsylvania Coal Company v. Mahon: "The general rule at least is, that while property may be regulated to a certain extent [under the police power], if regulation goes too far it will be recognized as a taking." 570 The Pennsylvania Coal analysis suggested that the police and eminent domain powers were on a continuum; if government went too far in the exercise of its regulatory function, that would amount to a taking.

The Holmes view in Pennsylvania Coal, a regulatory case, has served as an invitation to landowners to characterize regulatory actions as implicit exercises of eminent domain powers. That has the simultaneous benefit, from a landowner's perspective, of eliminating the permissive form of due process review and also suggesting the propriety of awarding compensation.

The Brandeis dissent in Pennsylvania Coal argued forcefully that the correlatives approach was mistaken. Justice Brandeis thought that substantive due process, not eminent domain, was the proper approach. The question should be whether the statute, which prohibited mining if that created subsidence of homes, was rationally related to a permissible legislative goal. ${ }^{571}$ Relying on cases such as Mugler $v$. Kansas, ${ }^{572}$ which had upheld against a substantive due process attack a state ban on the sale or manufacture of liquor, the dissent concluded that a legitimate goal, reasonably pursued, was valid, even if there were substantial economic hardships that resulted. The issue, for Justice

French Investing Co. v. City of New York, 39 N.Y.2d 587, 350 N.E.2d 381, 385 N.Y.S.2d 5 (1976), appeal dismissed, 429 U.S. 990 (1976).

566. See, e.g., Ellickson, supra note 9, at 493-509.

567. See Griggs v. Allegheny County, 369 U.S. 84 (1962); United States v. Causby, 328 U.S.

256 (1946); Van Alstyne, Taking or Damaging by Police Power: The Search for Inverse Condemnation Criteria, 44 S. Calif. L. Rev. I (1970).

568. "Fair" Compensation, supra note 547, at 1033.

569. Id.

570. Pennsylvania Coal Co. v. Mahon, 260 U.S. 393, 415 (1922).

571. Id. at 416-22 (Brandeis, J., dissenting).

572. 123 U.S. $623,668-69$ (1887). 
Brandeis, was to characterize the nature of the government's action-police or eminent domain-not to see them as loci along a single continuum of governmental action.

The Holmes approach in Pennsylvania Coal could be somewhat contained by the "public use" language of the takings clause. Even if the police and eminent domain powers were correlatives, there was at least the requirement that a taking be for a public use. A third factor in blurring the distinction between police and eminent domain powers was the Court's decision in Berman $v$. Parker. ${ }^{573}$ An eminent domain case involving the validity of an urban renewal program, Berman raised the issue whether condemnation of one private parcel for resale to another private owner constituted a public use under the Fifth Amendment. Justice Douglas for the Court competely obliterated any analytical role for the public use principle as a limitation on the eminent domain power. He appeared instead to treat the power of eminent domain as no different from any other exercise of governmental power-merely one means to an end. If the purpose were legitimate, the Court would not scrutinize the ultimate means by which government implemented its policy. ${ }^{574}$ In short, government could use the eminent domain power as it could any other power, without further judicial scrutiny. With the public use limitation thus eviscerated, the eminent domain power was no longer distinct analytically from other forms of governmental authority. Both were limited only by a public purpose requirement, which Berman made clear would be a policy judgment for legislatures to make unchecked by judicial review. Thus, there was little to stand in the way of characterizing excessive governmental regulation as a taking, even if there was no plausible governmental appropriation for public use.

The blurring of the eminent domain and police powers in state courts has thus been spurred by the demise of economic substantive due process, Holmes' "famous aphorism" in Pennsylvania Coal, and Douglas' fatal rendering of the public use limitation on eminent domain in Berman. The Supreme Court contributed by largely remaining aloof from the field. However, its recent decision in Penn Central Transportation Company $v$. New York City ${ }^{575}$ and its earlier decision in Goldblatt $v$. Town of Hempstead ${ }^{576}$ have provided certain insights into how the Court perceives some of these issues.

Goldblatt involved an ordinance that regulated dredging and pit excavating and had the effect of requiring the owner of an active sand and gravel mine

573. 348 U.S. 26 (1954).

574. Id. at 33. Justice Douglas wrote that "[t]he definition [of the police power] is essentially the product of legislative determinations addressed to the purposes of government . . . This principle admits of no exception merely because the power of eminent domain is involved .... Once the object is within the authority of Congress, the right to realize it through the exercise of eminent domain is ... merely the means to the end." Id. at 32-33.

575. 438 U.S. $104(1978)$.

576. 369 U.S. 590 (1962). 
to shut down. ${ }^{577}$ Although the Court indicated its apparent acceptance of the correlatives model of Pennsylvania Coal-noting that "[t]here is no set formula to determine where regulation ends and taking begins"578_-it analyzed the validity of the ordinance under the police power.

The ordinance prevented deepening a water filled pond below twenty-five feet; ${ }^{579}$ despite its skepticism about the marginal safety benefit from that prohibition, the Court concluded that there was insufficient evidence on reasonableness to rebut the general presumption of validity. ${ }^{580}$ Since the burden of proving unreasonableness rested on the challengers, and they had failed to meet it, the Court upheld the regulation as a valid police measure.$^{\mathbf{5 8 1}}$

Goldblatt is significant because it followed the police power cases such as Mugler, from which it quoted extensively. ${ }^{582}$ It applied a very restrained standard of review, relying on the landowner's failure to carry its burden of rebutting the presumption of validity. ${ }^{583}$ Nevertheless, while "the fact that [the regulation] deprives the property of its most beneficial use does not render it unconstitutional," ${ }^{584}$ the Court carefully noted that "there is no evidence in the present record which even remotely suggests that prohibition of further mining will reduce the value of the lot in question." ${ }^{585}$ From a formalistic point of view, that lack of evidence of diminution in value, however strained, made it easier for the Court not to treat the matter as a taking case.

Thus, the Pennsylvania Coal continuum (or correlatives) analysis seemed to

577. Id. at 592 .

578. Id. at 594. The Court also indicated that "governmental action in the form of regulation cannot be so onerous as to constitute a taking which constitutionally requires compensation." Id. See also Penn Central Transp. Co. v. New York City, 438 U.S. 104, 123 n.25 (1978).

579. 369 U.S. at 595.

580. Id. at 595-96.

581. Id. at 596 .

582. See id. at 593 .

583. Id. at 596. There are elements in Goldblatt that do not seem so restrained at all. For example, the Court suggests a balancing formula that would require that the means chosen by governmental action be "reasonably necessary" to achieve government's important ends. Id. at 594-95, quoting Lawton v. Steele, 152 U.S. 133, 137 (1894). Furthermore, in determining what is reasonable, the Court suggests evaluating "the nature of the menace against which it will protect, the availability and effectiveness of other less drastic protective steps, and the loss which [the property owner] will suffer from the imposition of the ordinance." 369 U.S. at 595 . These formulations have many elements in common with strict scrutiny under substantive due process, see Roe v. Wade, 410 U.S. 113 (1973), but are inconsistent with other economic substantive due process cases. E.g., Usery v. Turner Elkhorn Mining Co., 428 U.S. 1 (1976). Most significantly, however, in actually considering the facts in Goldblatt the Court declined to remand to overcome the "dearth of relevant evidence" in the record, 369 U.S. at 595, rather choosing to rely on the inadequacy of the record to justify a finding that the landowner failed to overcome the presumption of validity. In sum, despite some of the language in Goldblatt the actual form of review was extremely restrained.

584. Id. at 592

585. Id. at 594. Apparently, the Court "assumed that the ordinance did not prevent the owner's reasonable use of the property since the owner made no showing of an adverse effect on the value of the land." Penn Central Transp. Co. v. New York City, 438 U.S. 104, 127 (1978). 
be perpetuated, but with a subtle modification. Once categorizing the town's ordinance as a police regulation, the Court proceeded to determine only whether or not it was a permissible exercise of the police power. In essence, the Goldblatt Court regarded the police-eminent domain issue as a matter of threshold classification. ${ }^{586}$ To the extent that diminution in value was relevant (even if not conclusive), it and the parallel notion of alternative use were factors in determining whether the eminent domain or police power was involved. If a police measure, the regulation still had to pass the restrained due process reasonableness standard. If a taking, then presumably compensation would be required.

Goldblatt involved a prohibition on what was arguably a noxious use; governmental action could be justified on the ground that an externally harmful effect, albeit shy of a full-scale nuisance, was being combated. ${ }^{587}$ The Penn Central case, as Justice Rehnquist argued in dissent, ${ }^{588}$ could not fit easily into the same prevention-of-harm garb. There, New York City sought to restrict the right of the owner of Grand Central Terminal to construct a large office building that was otherwise allowed under the governing zoning ordinance. The rationale for the restriction was that "structures with special historic, cultural, or architectural significance enhance the quality of life for all." 589 No claim of negative externalities from the existing structure was made in support of the landmark law; rather, the external disbenefit stemmed from the alteration of the landmark as it currently existed. ${ }^{590}$

As in Goldblatt, the Court sought first to classify the landmark regulation as either an exercise of the eminent domain or police power. If an exercise of the former, presumably it would require compensation to be held valid; if an exercise of the latter, it would stand without compensation if reasonably related to a legitimate public purpose.

For the majority, Justice Brennan concluded that the landmark legislation did not impair the use of the existing terminal; furthermore, it did not "exploit[] ... for city purposes"591 the landowner's parcel, did not "facilitate[] . . . any entrepreneurial operations of the city," 592 nor did it "arise[] from" any such operations. ${ }^{593}$ In addition, Justice Brennan rejected the preventionof-harm/conferral-of-benefit dichotomy. Cases such as Goldblatt were "better

586. Id. at 592. For a discussion of other categorizational approaches, see Blumstein, supra note 153 , at 488 n.60.

587. See generally Hadachek v. Sebastian, 239 U.S. 394 (1915); Reinman v. City of Little Rock, 237 U.S. 171 (1915).

588. Penn Central Transp. Co. v. City of New York, 438 U.S. 104, 138 (1978) (Rehnquist, J., dissenting).

589. Id. at 108 .

590. Id. at 112 .

591. Id. at 135 .

592. Id.

593. Id. 
understood as resting not on any supposed 'noxious' quality of the prohibited uses but rather on the ground that the restrictions were reasonably related to the implementation of a policy-not unlike historic preservation-expected to produce a widespread public benefit and applicable to all similarly situated property." 594 In short, the city could reassign entitlements in land by establishing a public right in preserving its architectural heritage. Destruction or fundamental alteration of that heritage, in traditional terms, could then be characterized fairly as a prevention of harm..$^{595}$

The Court's analysis of the nature of the landmark regulation led it to the conclusion that the regulation should be treated as a police measure. ${ }^{596}$ Yet, the Court's further analysis of the regulation's validity as a police measure suggests a somewhat more stringent standard than Goldblatt. In Penn Central the Court found that the validity of the landmark law, as a police measure, turned on the "severity of the impact" of the measure on the relevant parcel. ${ }^{597}$ Arguably, that approach conforms to the analysis in Nectow, which, some have argued, established a reasonable beneficial use standard to measure the scope of permissible police power regulation. ${ }^{598}$ In Penn Central the Court found that the return from the present use of the terminal, the possibility that some project would be approved consistent with preservation of the landmark, and the opportunity to transfer the development rights above the terminal to nearby street parcels made the impact of the landmark regulation not unduly onerous. ${ }^{599}$

The Court's emphasis on reasonable beneficial use ${ }^{600}$ is somewhat puzzling, however, in light of earlier cases such as Mugler, in which the liquor manufacturing plant was rendered substantially useless. ${ }^{601}$ Under modern economic substantive due process doctrine, all the city would have to show is that its ordinance is reasonably related to a permissible police power goal. ${ }^{602}$ In stating its conclusion in Penn Central, however, the Court carefully noted the landmark not only met the rationality test but also satisfied the "reasona-

594. Id. at 134 n.30. The rejection of the harm/benefit distinction may be the most radical component of Penn Central. If noxious uses can be abated entirely, it seems that equating prevention of harm and conferral of benefit allows for dramatic expansion of government authority under the police power. The Court's discussion of reasonable beneficial use may suggest, however, that it did not intend some of the broader implications of its footnote 30. See text accompanying notes 596-607 infra.

595. 438 U.S. at $135,138$.

596. Id: at $130-35$.

597. Id. at 136 .

598. See, e.g., The Disparity Issue, supra note 547, at 411 \& nn.27 \& 28; Berger, supra note 547, at 817 .

599. 438 U.S. at $136-37$.

600. Id. at 138 .

601. See also Miller v. Schoene, 276 U.S. 272 (1928).

602. See cases cited in note 559 supra. 
ble beneficial use" standard. ${ }^{603}$ Although the Court's analysis in Penn Central is considerably closer to Justice Brandeis' dissent in Pennsylvania Coal than was Justice Holmes' majority opinion in that case, an adherence remains to a balancing formula to determine whether a governmental regulation has an excessive economic impact on "distinct investment-backed expectations."604

After Penn Central, then, it seems that the nature of the governmental action will predominate in determining whether or not an eminent domain issue is involved. The extent of the economic burden on the landowner will be involved primarily in determining whether a rational police measure is held valid. What Penn Central does not do, however, is explain why, in a police power context, the extra step of showing reasonable beneficial use is necessary. Unless the Court does not mean' its burial of the harm prevention/benefit conferral distinctions, ${ }^{605}$ it is unclear why the traditional deference of economic substantive due process analysis in other areas is inapplicable in a land use context. ${ }^{606}$

603. 438 U.S. at 138 .

604. Id. at 124 .

605. See id. at 133-34 n.30. Maintenance of the harm prevention/benefit conferral distinction, despite the difficulties in application, provides a benchmark for differentiating among different types of governmental interests. If government can totally abate a noxious use, irrespective of the magnitude of private harm, does the Court mean that it can similarly act to confer a benefit? The Court does not limit the taking concept to a transfer in "physical control," id. at 123 n.25. And it does impose a reasonable beneficial use limitation on governmental regulatory authority. But it is unclear how these are compatible with the broad governmental authority to restrict noxious uses if the prevention of noxiousness is not an analytically significanct component of those decisions. See id. at 133-34 n.30. Consequently, one of the ambiguous aspects of Penn Central is whether the Court really intended to obliterate the distinctions, and, if so, whether the reasonable beneficial use standard will prove to be a meaningful limitation on governmental authority. If it is a significant limitation, the further question for resolution is why such a requirement is part of the analysis and how it would be applied in a future noxiousness situation.

The analysis would be simpler, and more easily reconciled with economic substantive due process doctrine, if the reasonable beneficial use analysis were a part of the threshold inquiry on eminent domain versus police power. In that context the Court could quite properly focus on the "character of the [governmental] action and on the nature and extent of the interference with [private] rights," id. at 130, which stem from "distinct investment-backed expectations." Id. at 124. Moreover, obliteration of the harm prevention/benefit conferral distinction would no longer have such substantial implications because, presumably, other forms of distinctions can be drawn to help make the initial threshold determination of either eminent domain or police power. See, e.g., B. Ackerman, Private Property and the Constitution (1977); Michelman, Property, Utility, and Fairness: Comments on the Ethical Foundations of "Just Compensation" Law, 80 HARv. L. REv. 1165 (1967). What is so enigmatic and troubling about Penn Central is the police power mode of analysis, when combined with the imposition of the reasonable beneficial use criterion and the purported elimination of the harm prevention/benefit conferral distinction.

606. See F. Bosselman, D. Callies \& J. Banta, supra note 10, at 240-46. The Court's treatment of reasonable beneficial use in Penn Central suggests that the "nature and extent of the interference" with private property rights, 438 U.S. at 130, is an important part of the analysis under the police power. Although ambiguous, Goldblatt had indicated that these considerations were relevant in categorizing a governmental regulation at the threshold as either based on the eminent domain or police power. The analysis in Penn Central seems to establish reasonable beneficiai use as an independent criterion that must be satisfied even under a police power analysis. That is, 
While Penn Central does not explain satisfactorily why it adds an extra substantive element to a normal substantive due process analysis, it does provide a vehicle for approaching the compensation dilemma that has concerned Professor Costonis. ${ }^{607} \mathrm{He}$ has objected to the Holmes correlatives approach largely because of the compensation implications of a finding that excessive police regulation constitutes a taking. Once characterized as an eminent domain case, "just compensation" would be required, and the standard of just compensation has been defined as "highest and best use." ${ }^{608}$ The theory of "just compensation" is that there must be full compensation to the "full and perfect equivalent for the property taken."609

Costonis objects to use of the "just compensation" principle in cases of regulatory overreaching and has proposed a "middle way"610_a less generous standard of "fair" compensation in cases involving excessive regulation rather than conscious attempts at use of eminent domain powers. ${ }^{611}$ He has labeled the intermediate standard the accommodation power, applicable in "disparity genre" circumstances, ${ }^{612}$ and has suggested that compensation be paid by the

it appears to be a part of a due process balancing analysis rather than part of the initial categorization decision.

Read that way, the Penn Central decision apparently treats this species of economic due process case differently from others because such a balancing is not normally part of the deferential mode of analysis in the garden variety economic substantive due process context. The Court, in those circumstances, will look only at the legitimacy, not the weight, of a governmental interest and uphold the regulation if it is rational, despite the "severity of the impact," id. at 136, of the regulation on an individual's economic interest.

The Court's analytical framework can be interpreted in at least two ways. One is to suggest that the Court really does intend to put more teeth into substantive economic due process analysis when restrictions on land use are implicated. That would be consistent with Pennsylvania Coal and the Court's recent revival of contracts clause doctrine. See note 623 infra. It would not be consistent with developments over the last forty years in economic substantive due process, however.

Another view, more cynical perhaps, is that Penn Central actually reflects an even further erosion of constitutional protections for property interests than Goldblatt. See note 594 supra. This position would view the treatment of reasonable beneficial use in Penn Central skeptically. If the nature and degree of private harm are no longer mainstays of the threshold categorization decision, then it will be a lot easier to characterize a governmental action as falling under the police rather than the eminent domain power. That done, it will be difficult to rule in favor of a landowner in an economic substantive due process context, despite the reasonable beneficial use language of Penn Central, because of the Court's overwhelming reluctance to reenter the arena of active economic substantive due process review. The skeptical view, therefore, is that Penn Central withdraws consideration of private harm at the only point at which, pragmatically, it could really matter, and places it instead within an analytical context wherein it is doomed to desuetude.

607. See articles cited in note 547 supra.

608. The Disparity Issue, supra note 547, at 411; "Fair" Compensation, supra note 547, at 1042-45.

609. 438 U.S. at 150 (Rehnquist, J., dissenting) (quoting Monongahela Navigation Co. v. United States, 148 U.S. 312,326 (1893)).

610. The Disparity Issue, supra note 547, at 405.

611. See "Fair" Compensation, supra note 547. Professor Costonis's theory influenced the New York Court of Appeals when it decided the Penn Central case. See Penn Central Transp. Co. v. City of New York, 42 N.Y.2d 324, 331, 335, 366 N.E.2d 1271, 1275, 1277, 397 N.Y.S.2d 914, 918,921 (1977), aff'd, 438 U.S. 104 (1978).

612. The Disparity Issue, supra note 547, at 403 . 
amount which regulation diminished the value of property below its reasonable beneficial use. ${ }^{613}$

The Penn Central standard, which incorporates the reasonable beneficial use concept, could be adopted easily to Professor Costonis' end without necessitating development of the new "accommodation power" terminology. Thus, if a regulation failed to meet the reasonable beneficial use criterion of Penn Central, damages (rather than "compensation") could be awarded for the deprivation of property without due process of law. Now that civil rights causes of action lie against municipalities ${ }^{614}$ and have been inferred as arising directly from the Constitution itself, ${ }^{615}$ it seems appropriate to allow an aggrieved landowner to seek damages for harms to property beyond the valid bounds established under Penn Central. That form of relief would avoid the "just compensation" issue by adapting other due process damage precedents $^{616}$ to the land use context. It would also conform to the proposals of Professor Ellickson, who has advocated increased use of a damages remedy rather than injunctive relief. ${ }^{617}$ Predominant reliance on the injunction in the land use domain Ellickson has labeled the Nectow fallacy, ${ }^{618}$ after the decision that introduced its use. If Nectow were based on a substantive due process finding of arbitrariness, then arguably an injunctive remedy was appropriate. If, as Professors Berger ${ }^{619}$ and Costonis argue, ${ }^{620}$ it was the initiator of the reasonable beneficial use standard, then perhaps a damage award would have been proper, as suggested by Ellickson. ${ }^{621}$

The Penn Central case, in sum, backs away from a taking approach as per Pennsylvania Coal. It rather appears to adopt a threshold categorization mode of analysis to determine whether police or eminent domain power is involved. It goes further than traditional due process cases, however, in suggesting a judicial weighing of the economic impact on the landowner of a governmental action. That reflects an additional element of judicial scrutiny in substantive due process land use cases and could be used to achieve the compensation goals espoused by Professors Costonis and Ellickson. Whether the reason-

613. "Fair" Compensation, supra note 547, at 1049-52. See also Ellickson, supra note 9, at Sections IV \& X, and at 496 n.359.

614. See Monell v. Department of Social Services, 436 U.S. 658 (1978).

615. See Davis v. Passman, 99 S. Ct. 2264 (1979); Bivens v. Six Unknown Named Agents, 403 U.S. 388 (1971). See generally Dellinger, Of Rights and Remedies: The Constitution as a Sword, 85 Harv. L. Rev. 1532 (1972).

616. E.g., Carey v. Piphus, 435 U.S. 247 (1978) (denial of due process is actionable for nominal damages without proof of actual injury.).

617. See Ellickson, supra note 9, at 493-509.

618. Id. at $490-93$.

619. Berger, supra note 547 , at 817 .

620. The Disparity Issue, supra note 547, at 411.

621. Ellickson, supra note 9, at 493. 
able beneficial use factor in Penn Central actually represents a "straw in the wind" ${ }^{22}$ is difficult to tell because it was announced in the context of a decision that upheld a far-reaching regulatory program. Certainly the result in Penn Central is consistent with the overall narrowing of federal constitutional oversight of state actions that affect private economic interests. ${ }^{623}$

\section{Federal Statutory Limitations on}

\section{Governmental Land Use Decision Making}

While the Supreme Court has largely stayed out of local land use disputes, except upon a showing of racial discrimination, ${ }^{624}$ it has not similarly stopped development ${ }^{625}$ of statutory doctrine under the Fair Housing Act. ${ }^{626}$ In addition, it has dramatically opened the possibility of judicial enforcement of the federal antitrust laws against anticompetitive local government actions in the land use field. ${ }^{627}$ This Section will outline these federal statutory possibilities.

622. $C f$. G. Gunther, Constrtutional Law 125 n.* (9th ed. 1975) (noting Fry v. United States, 421 U.S. 542 (1975), as an "important straw in the wind" to the developing field of state sovereignty). Professor Gunther's observation was vindicated by the later decision of National League of Cities v. Usery, 426 U.S. 833 (1976), in which the Court indicated its growing sensitivity to state sovereignty considerations by overruling Maryland v. Wirtz, 392 U.S. 183 (1968).

623. See note 583, supra. But see United States Trust Co. v. New Jersey, 431 U.S. 1 (1977) (invalidating a state law that altered the backing of a public obligation as violative of the contracts clause); Allied Structural Steel Co. v. Spannaus, 438 U.S. 234 (1978) (invalidating under the contracts clause a state statute that substantially altered the terms of a private pension agreement).

624. See Village of Arlington Heights v. Metropolitan Hous. Dev. Corp., 429 U.S. 252 (1977); Mandelker, supra note 293.

625. It is clear that the Supreme Court has indeed arrested the development of federal constitutional law in the land use field, since it has reversed numerous decisions of lower courts in the area. See Young v. American Mini Theatres, Inc., 427 U.S. 50 (1976) (reversing court of appeals judgment that regulation dispersing "adult" theatres was unconstitutional); City of Eastlake v. Forest City Enterprises, 426 U.S. 668 (1976) (reversing Ohio Supreme Court finding that zoning change referendums violated federal constitutional due process guarantees); Washington v. Davis, 426 U.S. 229 (1976) (disapproving several lower court decisions that applied a disproportionate racial impact standard for determining race discrimination); Village of Belle Terre v. Boraas, 416 U.S. 1 (1974) (reversing court of appeals judgment invalidating zoning ordinance that restricted occupants of dwellings to one family, defined as persons related by blood or marriage); James $v$. Valtierra, 402 U.S. 137 (1971) (reversing district court ruling that a referendum on low-rent housing was impermissibly discriminatory).

626. 42 U.S.C. $\$ \$ 3601-3619,3631$ (1976). See generally Zoning Development, supra note 290, at 1679-94; Comment, Applying the Title VII Prima Facie Case to Title VIII Litigation, 11 Harv. C.R.-C.L. L. REV. 128 (1976).

627. See City of Lafayette v. Louisiana Power and Light Co., 435 U.S. 389 (1978). But see The Supreme Court, 1977 Term, 92 Harv. L. Rev. 57, 281 n.28 (1978). See generally Note, The Antitrust Liability of Municipalities Under the Parker Doctrine, 57 B.U. L. Rev. 368 (1977); Note, Antitrust Law and Municipal Corporations: Are Municipalities Exempt From Sherman Act Coverage Under the Parker Doctrine?, 65 Geo. L. J. 1547 (1977). 


\section{A. The Fair Housing Act}

The Fair Housing Act of 1968 provides one vehicle by which victims of exclusionary suburban land use practices may get relief without meeting the stringent standing ${ }^{628}$ and proof ${ }^{629}$ requirements under the Fourteenth Amendment's equal protection clause. Thus, in Trafficante $v$. Metropolitan Life Insurance Company, ${ }^{\mathbf{6 3 0}}$ the Supreme Court found "a congressional intention to define standing as broadly as is permitted by Article III."631 This expansive view of standing is in contrast to the much narrower prudential limitations on standing in Warth. The Court has interpreted the Fair Housing $\mathrm{Act}^{632}$ as expanding plaintiffs' standing to the maximum permissible under the Constitution, thereby effectively eliminating a denial of standing on prudential grounds in a Fair Housing Act case.

Substantively, the circuit courts of appeals have given greater scope to the prohibition on race discrimination in Title VIII than the Supreme Court has given to the nondiscrimination mandate of the equal protection clause. Under Washington v. Davis ${ }^{633}$ and Village of Arlington Heights v. Metropolitan Housing Development Corp., ${ }^{634}$ a plaintiff must show an intent to discriminate in an equal protection case. On remand in the Arlington Heights litigation, the seventh circuit held that a prima facie case of race discrimination could be established under the Fair Housing Act by a "showing of discriminatory effect without a showing of discriminatory intent." 635

Reaffirming its earlier conclusion that a refusal to rezone had a discriminatory effect, the seventh circuit held that the federal statute warranted application of an effect test because of its broad goal "to provide, within constitutional limitations, for fair housing throughout the United States." ${ }^{36}$ The circuit court drew an analogy to the Supreme Court's effect-based standard in the Title VII employment discrimination area, ${ }^{637}$ an approach left unaffected by the constitutional ruling in Washington and Arlington Heights. ${ }^{638}$

Section 3604(a) states in part that "it shall be unlawful to . . make unavailable or deny... a dwelling to any person because of race, color, religion,

\footnotetext{
628. See Warth v. Seldin, 422 U.S. 490 (1975); Section V.C.2 supra.

629. See Village of Arlington Heights v. Metropolitan Hous. Dev. Corp., 429 U.S. 252 (1977);

Washington v. Davis, 426 U.S. 229 (1976); text accompanying notes 34 1-373 supra.

630. 409 U.S. 205 (1972).

631. Id. at 209 (quoting Hackett v. McGuire Bros., Inc, 445 F.2d 442, 446 (3d Cir. 1971)).

632. 42 U.S.C. $\$ \$ 3601-3619,3631$ (1976) [hereinafter cited in text as Title VIII].

633. 426 U.S. 229 (1976).

634. 429 U.S. 252 (1977).

635. Metropolitan Hous. Dev. Corp. v. Village of Arlington Heights, 558 F.2d 1283, 1290

(7th Cir. 1977), cert. denied, 434 U.S. 1025 (1978).

636. 558 F.2d at 1289 (quoting 42 U.S.C. $\$ 3601$ (1970)).

637. See generally Griggs v. Duke Power Co., 401 U.S. 424 (1971).

638. See Washington v. Davis, 426 U.S. 229, 246-48 (1976).
} 
sex, or national origin." ${ }^{639}$ To give effect to the "because of race" language, the court "decline[d] to take a narrow view" 640 of the concept by requiring a showing of intent to discriminate. Noting that "attempts to discern the intent of an entity such as a municipality are at best problematic,"641 the court worried that "[a] strict focus on intent permits racial discrimination to go unpunished in the absence of evidence of overt bigotry." ${ }^{42}$ Yet, "evidence of intent has become harder to find" because "overtly bigoted behavior has become . . . unfashionable." ${ }^{43}$ For these reasons of policy, stemming from the court's perception of congressional design, the seventh circuit held that the statutory language "because of race" included "[c]onduct that has the necessary and foreseeable consequence of perpetuating segregation." ${ }^{44}$ That view, which had been taken by the eighth circuit in a case prior to Washington, ${ }^{645}$ has been followed by the third circuit, ${ }^{646}$ which was "most reluctant" 647 to require a showing of intent because it would raise a Title VIII "plaintiff's burden in proving a prima facie . . . case to a level almost commensurate with the burden of proof required to demonstrate an equal protection violation." ${ }^{648}$

While the circuits seem to be in agreement that a prima facie Fair Housing Act case can be established by evidence of segregative effect, they are not so uniform in their analytical approach once a prima facie case has been made out. ${ }^{649}$ In United States $v$. City of Black Jack ${ }^{650}$ the eighth circuit held that "[o]nce the plaintiff has established a prima facie case by demonstrating racially discriminatory effect, the burden shifts to the governmental defendant 2296 (1979) (" 'Discriminatory purpose'. . . implies more than intent as volition or intent as awareness of consequences. . . It implies that the decisionmaker . . selected or reaffirmed a particular course of action at least in part 'because of' not merely 'in spite of' its adverse effects upon an identifiable group.") Feeny, however, answered the constitutional question whether a veteran's preference statute which disproportionately benefited men was an invalid gender-based classification; Arlington Heights was based on the federal statutory issue. For a bleaker prognosis on the distinction between statutory and constitutional issues of discrimination, see General Electric Co. v. Gilbert, 429 U.S. 125 (1976), which applied the constitutional standard of Geduldig v. Aiello, 417 U.S. 484 (1974), in a statutory (gender-based discrimination) context.

645. United States v. Village of Black Jack, 508 F.2d 1179 (8th Cir. 1974), cert. denied, 422 U.S. 1042 (1975).

646. Resident Advisory Bd. v. Rizzo, 564 F.2d 126 (3d Cir. 1977), cert. denied. 435 U.S. 908 (1978).

647. 564 F.2d at 147 .

648. Id. at $146-47$.

649. But see Zoning Development, supra note 290 , at 1691 \& n.313. That commentator concludes that the compelling interest test developed by the eighth circuit predominates, despite the dissimilarity of the standard applied by the seventh circuit and the lack of congruence between the formula applied by the third circuit and that of the eighth circuit.
}

650. 508 F.2d 1179 (8th Cir. 1974). 
to demonstrate that its conduct was necessary to promote a compelling governmental interest." 651 The third circuit, however, has declined to accept "this heavy burden," 652 suggesting that "[f]or the present, Title VIII criteria must emerge ... on a case by case basis." ${ }^{653}$ While refusing to impose the full compelling interest standard, however, the third circuit did require that a defendant demonstrate a legitimate, nondiscriminatory rationale for its action and "that no alternative course of action could be adopted that would enable that interest to be served with less discriminatory impact."654 Thus, the third circuit standard requires judicial examination of alternatives but not necessarily of the weightiness of the community interest being served, only its legitimacy. ${ }^{655}$

The seventh circuit's position in Arlington Heights was considerably more complex. Judge Swygert, for the majority, identified four "critical factors" in determining when discriminatory impact, without discriminatory intent, violates section 3604(a) of the Fair Housing Act. ${ }^{656}$ Essentially, he outlined a balancing approach, indicating what factors cut which way and how they were to be weighed in assessing evidence.

The first factor is the strength of plaintiff's showing of discriminatory effect, "both in terms of disproportionate impact and in terms of racial segregation." 657 If the defendant's conduct perpetuates segregation and thereby prevents interracial association, it will be considered invidious under the Fair Housing Act, independent of the extent to which it produces a disparate effect on different racial groups. ${ }^{658}$

The second factor is whether there is evidence of some discriminatory intent, though not enough to establish a constitutional violation. Equitably, the case for relief is stronger where there is evidence that a defendant is a purposeful "wrongdoer," 659 but the court concluded that "this criterion is the least important of the four factors" 660 because "bigoted comments of a few citizens even those with power should not invalidate action which in fact has a

651. Id. at 1185. The court imposed "the compelling governmental interest requirement of the equal protection cases," id. at 1185 n.4, even though the case was based on a statute and not the fourteenth amendment. In the context of a private defendant Title VIII case, the eighth circuit has seemed to waver a bit on its standard, holding that a defendant can rebut a prima facie case by "satisfactorily explain[ing it] away." Smith v. Anchor Bldg. Corp., 536 F.2d 231, 233 (8th Cir. 1976).

652. Resident Advisory Bd. v. Rizzo, 564 F.2d 126, 148 (3d Cir. 1977).

653. Id. at 149 .

654. Id. If a defendant does offer evidence that no alternative course of action exists, "the burden will once again shift to the plaintiff to demonstrate that other practices are available." Id. at 149 n.37.

655. But see Zoning Development, supra note 290 , at 1691 n.313.

656. 558 F.2d at 1290.

657. Zoning Development, supra note 290 , at 1688 .

658. $558 \mathrm{~F} .2 \mathrm{~d}$ at 1290.

659. Id. at 1292 .

660. Id. 
legitimate basis." ${ }^{61}$ Moreover, "[i]f the effect of a zoning scheme is to perpetuate segregated housing, ... the preclusion of minorities in advance should [not] be favored over the preclusion of minorities in reaction to a plan which would create integration." 662

The third factor is the interest of the defendant in taking the action that causes the discriminatory effect. If the defendant is a private individual seeking to perpetuate segregated housing or a governmental body acting outside the scope of its authority or abusing its power, the court will be more ready to find a violation of the Fair Housing Act than if the defendant is a governmental body acting within the scope of is authority. ${ }^{663}$

The fourth factor is the nature of the relief sought. Courts "ought to be more reluctant to grant relief when the plaintiff seeks to compel the defendant to construct integrated housing or take affirmative steps to ensure that integrated housing is built than when the plaintiff is attempting to build integrated housing on his own land and merely seeks to enjoin the defendant from interfering with that construction." ${ }^{664}$

Concluding that the case was extremely close, the seventh circuit remanded for further consideration of effect, holding that if there is no land other than the plaintiff's property that is suitably zoned and otherwise qualified for federal support of subsidized low cost housing, the village's refusal to rezone would constitute a violation of $\S 3604(a) .{ }^{665}$ The defendant village, however, had the burden of identifying a suitable, alternative parcel. If it failed to satisfy that burden, then the trial court should grant relief to the plaintiffs since that would support a finding that "the [v]illage's refusal to rezone effectively precluded plaintiffs from constructing low-cost housing within Arlington Heights." 666

Whatever approach ultimately prevails-the compelling interest standard of the eighth circuit, the alternatives formula of the third circuit, or the "four critical factors" balancing approach of the seventh circuit-it is clear that the lower federal courts are more receptive to structural challenges to suburban zoning practices under the Fair Housing Act than the Supreme Court has

\section{Id.}

662. Id. at 1292-93.

663. Id. at 1293 .

664. Id.

665. Id. at 1294 .

666. Id. at 1295. Ultimately, the village and the plaintiffs reached a settlement in which the village agreed to annex a parcel of land beyond its corporate limits and to zone that land to conform with the plaintiffs' planned uses. Metropolitan Hous. Dev. Corp. v. Village of Arlington Heights, 469 F. Supp. 836 (N.D. Ill. 1979). Mount Prospect, a nearby community, sought to intervene to contest the settlement agreement because of "its potential effect on the citizens of Mount Prospect." Id. at 843. Other area landowners and civic associations also sought intervention. Id. at 844. The court held that the intervenors "have a legal interest in the annexation and rezoning of the neighboring land." $I d$. at 860 . They did not, however, present any zoning-related objections sufficient to block entry of the decree, and the consent decree was entered. $I d$. at 869 . 
been in its interpretation of the constitutional guarantee of equal protection. ${ }^{667}$ The adoption of the impact test for establishing a prima facie case of race discrimination and the relaxation of prudential standing barriers ${ }^{668}$ make plaintiffs' prospects under the Fair Housing Act reasonably promising.

\section{B. Antitrust Liability and the Narrowing of the State Action Exemption}

By imposing various restrictive land use practices, local governments typically constrain the availability of housing in that community by slowing the rate of increase in supply. ${ }^{669}$ Unless the consumer demand for housing in a given suburb is completely elastic, ${ }^{670}$ the owners of existing housing "can employ growth controls to cartelize housing supply."671 If suburbs can successfully restrict new housing development, the value of suburban homeowners' property will increase since the price of used housing in that jurisdiction will rise, and " $[t]$ he more unique a suburb . . ., the more lucrative the monopoly possibilities for its homeowners." ${ }^{672}$ Thus, Professor Ellickson concludes that "[a]ntigrowth measures have one premier class of beneficiaries: those who own residential structures in the municipality doing the excluding." 673 Where suburban homeowners, acting in their self-interest, dominate the suburban political process, ${ }^{674}$ government officials may well be seen as acting "as perfect agents for a homeowner cartel."675

667. In the area of standing, the Supreme Court has been considerably more liberal in interpreting Title VIII than it has been in fourteenth amendment challenges. See Gladstone v. Village of Bellwood, 441 U.S. 91 (1979).

668. Id. See also Trafficante v. Metropolitan Life Ins. Co., 409 U.S. 205 (1972).

669. See generally Ellickson, supra note 9, at 392-403; Note, supra note 193.

670. Demand for housing in a suburb that has perfect substitutes is perfectly elastic-in other words, the demand curve is horizontal. When a fungible suburb imposes development charges or wasteful development standards on its homebuilders, those homebuilders are unable to pass on any of those costs to housing consumers. Why should a homebuyer pay more when he can purchase an equally good house at the old price in another essentially identical suburb? When suburbs are perfectly competitive, the burden of municipal antigrowth programs falls entirely on the producers' surplusthe economic rents of owners of supply factors.

Ellickson, supra note 9, at 425 (footnote omitted). See generally id. at 425-30.

671. Id. at 400. See generally id. at 430-35.

672. Id. at 400 .

673. Id.

674. See id. at 404-10.

675. Id. at 410. As Professor Ellickson further notes, suburbs may take advantage of a real possibility to enhance monopoly profits by joining similar area suburbs to impose growth restrictions. Id. at 434. This form of "voluntary cartel" restricts the supply of housing and raises prices. However, these voluntary arrangements easily fall apart, since the incentive for a cheating member to collect "the lucrative development charges made possible by the monopoly prices" is tremendous. Id. at 434. Professor Ellickson suggests that:

[w] hat the conspiring suburbs need is a cartel manager able to coerce all members to comply with stipulated output restrictions. A higher government is obviously the best candidate to perform this function. For example, a regional body with the authority to enforce a sewer connection moratorium can effectively police the output of new housing within many suburbs. 
Despite the patent antitrust implications of much antigrowth activity, antitrust lawsuits have not been brought because of a widespread belief that "local governments would not be vulnerable to suits based on the federal antitrust laws." ${ }^{676}$ The basis for that belief was the doctrine of antitrust immunity established in Parker v. Brown ${ }^{677}$ - that the Sherman Act was meant to apply to "individual and not state action." ${ }^{678}$ By its recent decision in City of Lafayette $v$. Louisiana Power E Light Co. ${ }^{679}$ however, the Supreme Court has held that Parker immunity for "state action" will not be extended automatically to actions of local governments. ${ }^{680}$ The remainder of this Subsection will discuss the Parker doctrine, propose an analytical framework for resolving Parker issues, and consider the implications of the City of Lafayette case for prospective challenges of local land use restrictions.

The Parker case was a challenge to the California Raisin Proration Program, which was designed to stabilize raisin prices within California by allowing state officials to appropriate a certain amount of each producer's output. The Court assumed that "the California prorate program would violate the Sherman Act if it were organized and made effective solely by virtue of a contract, combination or conspiracy of private persons, individual or corporate" 681 and noted that price competition among producers had been effecfively eliminated by the program. ${ }^{\mathbf{6 8 2}}$ Nevertheless, the Court declined to find an antitrust violation because the state program "derived its authority and its efficacy from the legislative command of the state" ${ }^{83}$ and because there was no explicit congressional statement that the Sherman Act was iritended "to restrain a state or its officers or agents from activities directed by its legisla-

Id. Ironically, the conventional solution to exclusionary land use practices is the development of a regional governing body with broader jurisdiction than any single local unit of government. Professor Ellickson's analysis suggests that these regional bodies may perform quite a different function than the one planners envision. Even though their political constituencies will be rather different from those of the suburban units they supervise, there is a clear risk of increased anticompetitive activity, whether developers or homeowners ultimately control the activities of the regional agency.

676. Id. at 470 n.249.

677. 317 U.S. 341 (1943). See generally 1 P. Areeda \& D. Turner, Antitrust Law 99 207-2 18 (1978); Donnem, Federal Antitrust Laws Versus Anticompetitive State Regulation, 39 AnTITRuST L.J. 950 (1970); Handler, Anti-trust-1978, 78 Colum. L. Rev. 1363, 1374-88 (1978); Handler, The Current Attack on the Parker v. Brown State Action Doctrine, 76 Colum. L. Rev. 1 (1976); Posner, The Proper Relationship Between State Regulation and the Federal Antitrust Laws, 49 N.Y.U. L. REv. 693 (1974); Slater. Antitrust and Government Action: A Formula for Narrowing Parker v. Brown, $69 \mathrm{Nw}$. U.L. Rev. 71 (1974); Verkuil, State Action, Due Process and Anti-trust: Reflections on Parker v. Brown, 75 Colum. L. Rev. 328 (1975); Comment, The State Action Exemption in Antitrust: From Parker $v$.

Brown to Cantor v. Detroit Edison Co., 1977 Duke L.J. 871.

678. 317 U.S. at 352 .

679. 435 U.S. 389 (1978).

680. See generally The Supreme Court, 1977 Term, supra note 627, at 277-88 (1978).

681. 317 U.S. at 350 .

682. Id. at 359 .

683. Id. at 350 . 
ture." ${ }^{684}$ Chief Justice Stone made the Court's rationale clear: "In a dual system of government in which, under the Constitution, the states are sovereign, save only as Congress may constitutionally subtract from their authority, an unexpressed purpose to nullify a state's control over its officers and agents is not lightly to be attributed to Congress." 685 Thus, out of deference to our constitutional system of federalism, ${ }^{686}$ in which "the states are sovereign," ${ }^{687}$ the Court in Parker refused to infer a congressional "purpose that the antitrust laws be used to strike down the State's regulatory program imposed as an act of government" absent a clear statement of congressional intent. ${ }^{688}$

The Court's unwillingness in Parker to read the Sherman Act's coverage expansively has clear constitutional overtones. Over time the Court has broadened the Act's scope as contemporary concepts of federal power under the commerce clause have expanded. ${ }^{689}$ The continued vitality of the Parker exemption must mean that the Court's restrictive interpretation of the Sherman Act's application to "state action" is influenced by constitutional considerations of federalism. ${ }^{600}$ These principles are derived from the Tenth and Eleventh Amendments to the Constitution and a full understanding of the scope of the Parker exemption must take into account the federalism values of both the Tenth and Eleventh Amendments.

The Parker doctrine is best understood as incorporating a "double exemption," 691 each stemming from a distinct constitutional source of federalism: “one reflecting the states' eleventh amendment sovereign immunity and the other reflecting a recognition of the states' tenth amendment reserved powers." ${ }^{692}$ Much confusion has arisen in Parker cases because various coalitions of justices have failed to communicate the dual nature of the Parker exemption, not recognizing the different constitutional sources for the twin strands of the Parker rule. ${ }^{693}$

684. Id. at $350-51$.

685. Id. at 351 .

686. See generally City of Lafayette v. Louisiana Power and Light Co., 435 U.S. 389, 418

(1978) (Burger, C.J., concurring); 1 P. AreedA \& D. TuRner, supra note 677, at 212.

687. 317 U.S. at 351 .

688. 435 U.S. at 407 n.33.

689. See Ciry of Lafayette v. Louisiana Power and Light Co., 435 U.S. 389, 421 (1978) (Burger, C. J., concurring); Cantor v. Detroit Edison Co., 428 U.S. 579, 605 (1976) (Blackmun, J., concurring); id. at 614 (Stewart, J., dissenting); Hospital Bldg. Co. v. Rex Hosp. Trustees, 425 U.S. 738, 743 n.2 (1976). See generally Blumstein \& Calvani, State Action as a Shield and a Sword in a Medical Services Antitrust Context: Parker v. Brown in Constitutional Perspective, 1978 Duke L. J. 389, $419-21$. 690. I P. AREeda \& D. Turner, supra note 677, at $\$ 212$. See City of Lafayette v. Louisiana Power and Light Co., 435 U.S. 389, 421 (1978) (Burger, C.J., concurring).

691. Blumstein \& Calvani, supra note 689, at 394-95.

692. Id. at 394 .

693. For instance, although Justices Stevens, Brennan, White, Marshall, Blackmun and Chief Justice Burger agreed that no exemption should be applied in Cantor, only Justices Brennan, White and Marshall joined in all of Justice Stevens' opinion. Chief Justice Burger concurred in the judgment and in Parts $I$ and III of the Stevens opinion, making them a majority holding of 
The division among the justices is manifest in the case of Cantor $v$. Detroit Edison Co., ${ }^{694}$ a challenge to Detroit Edison's light bulb exchange program. Under the program, which was included in the tariff the utility filed with the state regulatory commission, the company furnished its residential customers with "free" replacement light bulbs, incorporating the cost of the bulbs in the overall price of electricity. A druggist who sold electric light bulbs claimed that the utility was using its monopoly power in the distribution of electricity to restrain competition in the light bulb market.

A majority of the Court agreed that private parties could not rest their claim of exemption solely on the ground that their activity was compelled by the state regulatory commission. ${ }^{695}$ Even on the assumption that there was a defense based on state compulsion, ${ }^{696}$ the Court held that such a defense was unavailable unless "the State's participation in the decision is so dominant that it would be unfair to hold a private party responsible for his conduct implementing it ...."697 The light bulb program did not qualify for exemption because the decision whether to have such a program was initiated by the utility, not the state agency. ${ }^{698}$ Therefore, "notwithstanding the state participation in the decision, the private party exercised sufficient freedom of choice" to justify a conclusion that it "should be held responsible for the consequences of [its] decision." ${ }^{699}$

A majority of the Court agreed on another conclusion, rejecting the utility's contention that "the federal antitrust laws should not be applied in areas of the economy pervasively regulated by state agencies."700 The Court found no "logical inconsistency" 701 in requiring a private firm to meet regulatory criteria when "exercising its natural monopoly powers" and also "to comply with

the Court. Justice Blackmun concurred in the judgment but used a different analytical approach. Justices Stewart, Powell, and Rehnquist dissented.

In City of Lafayette Justices Blackmun and White joined Justices Stewart and Rehnquist in dissent. In Cantor Justice White had joined all of the Stevens opinion while Justice Blackmun had concurred in the judgment. Justice Powell joined the plurality in City of Lafayette even though he dissented in Cantor. The Chief Justice concurred in both Cantor and City of Lafayette, but, while portions of Cantor are legitimate Court holdings, it is doubtful that any analytical component of City of Lafayette's Parker discussion commanded the allegiance of a majority of the justices.

For an attempt at reconciling at least some of these votes, see Blumstein \& Calvani, supra note 689 , at $411 \mathrm{n} .133$.

694. 428 U.S. 579 (1976).

695. "It is not enough that . . anticompetitive conduct is 'prompted' by state action; rather, anticompetitive activities must be compelled by direction of the State acting as a sovereign." Goldfarb v. Virginia State Bar, 421 U.S. 773, 791 (1975). See generally 1 P. Areeda \& D. Turner, supra note 677 , at 1215 .

696. The Court assumed this arguendo. 428 U.S. at 592. See I P. Areeda \& D. Turner, supra note 677 , at $9215 \mathrm{~b}$; Blumstein \& Calvani, supra note 689 , at 406.

697. 428 U.S. at 594-95.

698. Id. at $594 \&$ n.31.

699. Id. at 593 .

700. Id at 595 .

701 . Id. at 596. 
antitrust standards" when competing with unregulated business activity. ${ }^{702}$ To determine whether an antitrust exemption applies the Court suggested a twostep test. First, is the antitrust exemption "necessary in order to make the regulatory act work?"703 Second, does the regulation in question go beyond the "minimum extent necessary"704 to accomplish its goal? Since the light bulb program competed with the "essentially unregulated" market for electric light bulbs, ${ }^{705}$ the Court concluded that the program was scarcely necessary to further the state's "interest in regulating its utilities' distribution of electricity."

While a majority in Cantor agreed on the foregoing substantive approach to Parker immunity, ${ }^{707}$ a four-member plurality argued that Parker did not apply at all to private defendants. ${ }^{708}$ Justice Stevens noted that "[t]he federal statute proscribes the conduct of persons, not programs, and the narrow holding in Parker concerned only the legality of the conduct of state officials charged by law with the responsibility for administering California's program." ${ }^{709}$ Justice Stevens further observed that the Supreme Court "has never sustained a claim that otherwise unlawful private conduct is exempt from the antitrust laws because it was permitted or required by state law," 710 and he argued that Parker applied only when state officials were sued in their official capacities. ${ }^{711}$ Since the complaint in Cantor did not challenge "the legality of any act of the state of Michigan or any of its officials or agents," the plurality concluded that it was "not controlled by the Parker decision."712

The plurality's approach in Cantor-what might be construed as a procedural approach to Parker since it focuses on the identity of the parties $-{ }^{713}$

\footnotetext{
702. Id.

703. Id. at 597 .

704. Id. (quoting Otter Tail Power Co. v. United States, 410 U.S. 366, 391 (1973)).

705. 428 U.S. at 595.

706. Id. at 598 .

707. The Cantor majority consisted of Justices Stevens, Brennan, White, Marshall, and Chief Justice Burger. See note 693 supra.

708. Chief Justice Burger did not join in Sections II and IV of the majority opinion written by Justice Stevens. Justice Blackmun concurred in the judgment, but he reached his conclusion by means of a different analytical mode. See note 693 supra.

709. The opinion continues: "What sort of charge might have been made against the various private persons who engaged in a variety of different activities implementing that program is unknown and unknowable because no such charges were made." 428 U.S. at 601 .

710 . Id. at 600 .

711 . Id. at 591 .

712. Id. at 591-92. See note 722 infra and accompanying text. Justice Stevens took a narrow view of the term "state action." Although he acknowledged that the term "may be used broadly to encompass individual action supported to some extent by state law or custom," id. at 590 , he argued that such a broad definition was not applicable in Parker situations. Justice Stevens believed that the references in Parker to state action were "carefully drafted" and "unequivocably differentiate[d] between official action, on the one hand, and individual action (even when commanded by the State), on the other hand." Id. at $591 \mathrm{n} .24$.

713. That is, "a plaintiff might be able to circumvent Parker simply by suing an appropriate defendant." Blumstein \& Calvani, supra note 689 , at 407 . This possibility was actually suggested by the plurality in Cantor. 428 U.S. at 601 . See note 709 supra.
} 
"would suggest that the state action exemption is available only to a state and its officials (and perhaps certain of its subdivisions) although immunity would not automatically be conferred on all governmental agencies or units." ${ }^{14} \mathrm{Al}$ though the diverseness of opinions in Cantor confuses more than it enlightens, at least one important conclusion can be drawn: Parker issues should be analyzed differently when private parties are sued than when governmental programs or official conduct are challenged.

The best way to reconcile the differing approaches ${ }^{715}$ is to recognize the dual sources of Parker doctrine. The procedural concern of the Cantor plurality can be understood as a manifestation of a sensitivity toward the proper "relationship between the sovereign states and the antitrust laws."716 The holding in Georgia v. Evans, ${ }^{717}$ that a state could maintain an action for treble damages as a "person" under the Sherman Act, "generated the logical next question-whether a state could in turn be sued and held liable for damages." ${ }^{18}$ Analyzed in that manner, it is clear that Parker raised considerations of Eleventh Amendment federalism, concerning the "susceptibility of states to suits in federal courts; subjecting a state or its officials acting in their official capacities-the situation in Parker $v$. Brown-to antitrust liability would seem to conflict with the policy embodied in the Eleventh Amendment." "719

The Eleventh Amendment source for Parker suggests ${ }^{720}$ a limitation of the Parker exemption to actions of certain state agencies and officials, not to pri-

714. Blumstein \& Calvani, supra note 689, at 408.

715. The five justices who did not join the plurality all advocated a more substantive approach. The dissenters (Justices Stewart, Powell and Rehnquist) "would have exempted all statecompelled activity, even when the impetus for governmental compulsion was essentially self-initiated." Blumstein \& Calvani, supra note 689 , at 408 . Chief Justice Burger, however, while objecting to an exclusive focus on the identity of the defendant and arguing for a more substantive effect for Parker, failed to indicate which activities should be protected. Id. Justice Blackmun, on the other hand, suggested a formula to use in separating exempt and non-exempt activities. He proposed "a rule of reason approach," $i d$., for "state-sanctioned anticompetitive activity must fall like any other if its potential harms outweigh its benefits." 428 U.S. at 610 . Justice Blackmun advocated balancing the "implicated federal and state interests with a view to assuring that when these are truly in conflict, the former prevail." Id. at 611 .

716.428 U.S. at 587.

717. 316 U.S. 159 (1942). This case was decided contemporaneously with Parker.

718. Blumstein \& Calvani, supra note 689. at 414.

719. Id. at 414-15. Cf. I P. Areeda \& D. Turner, supra note 677, at I 217 al (*[T] Amendment ... does raise a substantial bar to damage actions in many suits against state officials").

720. This analysis is not meant to suggest that the Parker doctrine is coextensive with the eleventh amendment. It is clear, for example, after Edelman $v$. Jordan that suits for injunctive relief are not barred by the eleventh amendment. If the Parker doctrine had no independent force beyond the narrow limits of the eleventh amendment then the decisions in Bates and Parker themselves would have been incorrect because in neither case was the plaintiff seeking damages from the state. Therefore, while the Parker doctrine is built in part on the same concerns of federalism that underlie the eleventh amendment, that doctrine certainly goes further than the requirements of the Constitution.

Blumstein \& Calvani, supra note 689 , at 417 (footnotes omitted). 
vate parties. In light of Cantor, however, only a plurality of the Court would accept the procedural approach as the exclusive form of state action exemption, ${ }^{721}$ even though all Supreme Court cases in which the Parker exemption has actually been applied have involved actions by state governmental defendants. ${ }^{722}$

The four Cantor dissenters and Chief Justice Burger articulated a view of the Parker exemption that closely paralleled the Tenth Amendment's concept of reserved powers as that notion was developed in National League of Cities $v$. Usery. ${ }^{723}$ In urging that Parker not be read narrowly, the Cantor dissenters argued that erosion of Parker would allow intrusion of federal policies on the traditional authority of states to perform social and economic regulatory functions. ${ }^{724}$ The dissenters were also apprehensive of an expansion of federal judicial interventionism in state regulatory matters under a vaguely worded federal statute that furnishes courts little guidance and therefore affords them considerable discretion to make and federalize state social and economic policy. ${ }^{725}$

Many of the concerns of the Cantor dissenters reflect those of the majority in Usery, in which the Court held invalid federal minimum wage and maximum hour standards as they applied to state and local government employees performing essential governmental functions. ${ }^{726}$ While recognizing the broad scope of federal power under the commerce clause, the Court in Usery noted that "there are attributes of sovereignty attaching to every state government which may not be impaired by Congress, not because Congress may lack an affirmative grant of legislative authority to reach the matter, but because the Constitution prohibits it from exercising the authority in that manner."727 Thus, Congress cannot "impair[] the State's integrity" 728 nor "abrogate"729

721. See id. at 419. Accord, 1 P. Areeda \& D. Turner, supra note 677 , at $\$ 212 \mathrm{~b}$.

722. See New Motor Vehicle Bd. v. Orrin W. Fox Co., 439 U.S. 96, 109-10 (1978); Bates v. State Bar of Ariz., 433 U.S. 350 (1977); Parker v. Brown, 317 U.S. 341 (1943). See also Exxon Corp. v. Governor of Md., 437 U.S. 117 (1978).

723. 426 U.S. 833,856 (1976).

724. 428 U.S. at 631, 637. See generally Handler. Changing Trends in Antitrust Doctrine: An Unprecedented Supreme Court Term-1977, 77 Colum. L. Rev. 979, 1009-13; Handler, The Current Attack on the Parker v. Brown State Action Doctrine, supra note 677, at 17-20; Verkuil, supra note 677, at 334. See also Exxon Corp. v. Governor of Md., 437 U.S. 117 (1978).

725. 428 U.S. at 640. See Verkuil, supra note 677 , at 332-35. But see City of Lafayette v. Louisiana Power and Light Co., 435 U.S. 389, 416 n.46 (1978) ("Restating a theme made and rejected before, . . . our Brother Stewart's dissent . . likens judicial enforcement of the antitrust laws to a regime of substantive due process used by federal judges to strike down state and municipal economic regulation thought by them unfair. That analogy . . ignores the congressional judgment mandating broad scope in enforcement of the antitrust laws and simply reflects the dissent's view that such enforcement with respect to cities is unwise."); Blumstein \& Calvani, supra note 689 , at $428-31$.

726. 426 U.S. at 845 .

727. Id.

728. Fry v. United States, 421 U.S. 542,547 n.7 (1975).

729. 426 U.S. at 846 . 
state authority with respect to "functions essential to [a state's] separate and independent existence."730

The concerns and analytical approach in Usery are closely related to the rationale of the Parker exemption. ${ }^{731}$ As in Usery, the scope of federal power is broad since the federal antitrust law has been interpreted broadly under the commerce power. ${ }^{732}$ The antitrust exemption formulated in Parker reflects a sensitivity on the part of the Court to extending federal antitrust coverage to include state action. Parker thus serves to limit the breadth of application of the Sherman Act because of the Tenth Amendment's principles of reserved powers, which command respect for activities of state government. Consequently, in interpreting the scope of the state action antitrust exemption, it is appropriate to incorporate Usery's principles of federalism as a second strand of the Parker analysis. Importantly, Usery, applying Tenth Amendment principles, did not distinguish between state and local governments, ${ }^{733}$ whereas traditional Eleventh Amendment immunity extends only to the state itself and to political subdivisions that can properly be viewed as agents of the state and therefore entitled to the state's immunity. ${ }^{734}$

Application of Usery principles in a Parker context provides the second facet of the dual exemption analysis. For these purposes three components derived from Usery form the analytical framework:

first, there must be an attribute of sovereignty involved; second, the state activity must be an essential governmental function; and third, there must be an impairment of that state function..$^{735}$

The City of Lafayette decision provided an opportunity to clarify Parker analysis, but instead it contributed to the perpetuation of analytical disarray, since no majority opinion was handed down. ${ }^{736}$ In City of Lafayette the city, which owned and operated an electric utility, sued an investor-owned electric service utility alleging a variety of antitrust violations. ${ }^{737}$ The private utility counter-claimed, charging the city with committing sundry violations of fed-

730. Id. at 845 (quoting Coyle v. Oklahoma, 221 U.S. 559, 580 (1911)).

731. See generally Davidson \& Butters, Parker and Usery: Portended Constitutional Limits on Federal Interdiction of Anticompetitive State Action, 31 V AND. L. REv. 575, 597-604 (1978).

732. See Cantor v. Detroit Edison Co., 428 U.S. 579, 605 (1976) (Blackmun, J., concurring); Hospital Bldg. Co. v. Trustees of Rex Hosp., 425 U.S. 738,743 n.2 (1976).

733. 426 U.S. at 855-56 n.20. See City of Lafayette v. Louisiana Power and Light Co., 435 U.S. 389, 430 (1978) (Stewart, J., dissenting).

734. See Mt. Healthy City Bd. of Educ. v. Doyle, 429 U.S. 274, 280 (1977). See generally L.

TRIBE, supra note 347 , at $\$ \$ 3-35$ to $-36,3-38$.

735. Blumstein \& Calvani, supra note 689, at 424.

736. Justice Brennan wrote the prevailing opinion. Chief Justice Burger and Justices Marshall, Powell and Stevens joined in Part $I$ and Justices Marshall, Powell and Stevens joined in Parts II and III. In addition, Justice Marshall filed a concurring opinion, while the Chief Justice wrote an opinion concurring in the judgment. Justices White and Rehnquist concurred in Justice Stewart's dissent, and Justice Blackmun concurred in all but one portion of that dissent.

737. 435 U.S. at $391-92$ \& n.5. 
eral antitrust law. ${ }^{738}$ The city moved to dismiss on the ground that, as a city and political subdivision of the State of Louisiana, it was not subject to the federal antitrust laws under Parker v. Brown.

A four-justice plurality rejected the city's argument that "all governmental entities, whether state agencies or subdivisions of a State, are, simply by reason of their status as such, exempt from the antitrust laws." ${ }^{739}$ Writing for the plurality, Justice Brennan noted that "[c]ities are not themselves sovereign; they do not receive all the federal deference of the States that create them."740 Parker exemption should not automatically be extended to local governments because of the "serious economic dislocation"741 that could come from "anticompetitive municipal action" that placed cities' "parochial interests above the Nation's economic goals reflected in the antitrust laws . . ."742 However, while cities will not be accorded automatic Parker exemption, the "actions of municipalities [that] reflect state policy"743 are exempt. In sum, "the Parker doctrine exempts only anticompetitive conduct engaged in as an act of government by the State as sovereign, or, by its subdivisions, pursuant to state policy to displace competition with regulation or monopoly public service." 744

The plurality's approach in City of Lafayette largely reflects a reliance on the "official action" reading of Parker suggested by the plurality in Cantor. Justice Brennan noted that policies adopted by cities may reflect their own preferences rather than those of the state. ${ }^{745}$ Because of the difference in respect accorded states and their political subdivisions, a characteristic of Eleventh Amendment case law, ${ }^{746}$ the plurality was unwilling to find a Parker exemption "in the absence of evidence that the State authorized or directed a given municipality to act as it did." ${ }^{747}$ Although a political subdivision need not point to "a specific, detailed legislative authorization" to qualify for Parker immunity, ${ }^{788}$ it must show "that the legislature contemplated the kind of action complained of."749 In essence, for the plurality the crucial question was whether a municipality acted as the agent of the state, effectuating stateinitiated policies, in performing the challenged activities. ${ }^{750}$ The Eleventh

738. Id. at 392 \& n. 6 .

739. Id. at 408. A majority, which included Chief Justice Burger, agreed that, apart from the exemption outlined in Parker, there was no blanket exemption from federal antitrust laws for cities as such. Id. at 394-408.

740. Id. at 412. Justice Brennan found support for his statement in Edelman v. Jordan, 415 U.S. 651,677 n.12 (1974) and Lincoln County v. Luning, 133 U.S. 529 (1890).

741. 435 U.S. at 412.

742. Id. at 413 .

743. Id.

744. Id.

745. Id. at 414

746. See note 734 supra, and accompanying text.

747. 435 U.S. at 414.

748. Id. at 415 .

749. Id. (quoting City of Lafayette v. Louisiana Power and Light Co., 532 F.2d 431, 434 (5th Cir. 1976)).

750. Blumstein \& Calvani, supra note 689 , at 411 n. 133 
Amendment strand of analysis was apparent, and Justice Brennan in fact cited Eleventh Amendment cases to bolster his argument. ${ }^{751}$ At the same time, he emphatically rejected the dissent's suggestion that National League of Cities $v$. Usery $^{752}$ was "even tangentially implicated," 753 thereby declining to adopt a Tenth Amendment analysis.

In his concurrence, the Chief Justice did not focus on the difference between a state and its political subdivisions for Parker analysis. Rather, he emphasized the nature of the "challenged activity, not . . the identity of the parties to the suit."754 For the Chief Justice, the general question of the Sherman Act's coverage of "the monopoly powers of state and local governments" 755 was "not presented by . . . the facts" in City of Lafayette ${ }^{756}$ The Parker issue was "whether the Sherman Act reaches the proprietary enterprises of municipalities," ${ }^{757}$ and Chief Justice Burger carefully noted that at the time Parker was decided "the Court had already recognized, for purposes of federalism, the difference between a state's entrepreneurial personality and a sovereign's decision ... to replace competition with regulation." ${ }^{758}$ Only where the state as sovereign compelled the anticompetitive activity in question pursuant to "an articulated policy to displace competition with regulation" 759 would Parker's exemption apply.

Chief Justice Burger explicitly recognized that "[t]he Parker decision was . . . firmly grounded on principles of federalism," ${ }^{760}$ but concluded that Usery, "which rekindled a commitment to tempering the Commerce Clause power with the limits imposed by our structure of government," ${ }^{761}$ was the appropriate source of federalism principles to govern City of Lafayette. Relying on standards articulated in Usery, the Chief Justice argued that only "functions essential to [a state's] separate and independent existence" ${ }^{\text {762 }}$ were incorpora-

751. 435 U.S. at $412 \&$ n.42, 414 n.43. Compare id. with id. at 430 (Stewart, J., dissenting).

752. 426 U.S. $833(1976)$.

753. 435 U.S at $412-13$ n.42.

754. Id. at 420 (quoting Cantor v. Detroit Edison Co., 428 U.S. 579, 604 (1976)) (emphasis in original).

755. 435 U.S. at 422 .

756. Id.

757. $I d$.

758. Id.

759. Id. at 425 n.6. See id. at 418; Goldfarb v. Virginia State Bar, 421 U.S. 773,791 (1975). Cf. I P. Areeda \& D. Turner, supra note 677, at $1214 \mathrm{e}$ (“[T] of state authorization must be subject to a clear statement requirement"); The Supreme Court, 1977 Term, supra note 627, at 282 (concluding that a clear statement requirement is reasonable). See generally Blumstein \& Calvani, supra note 689 , at 427-28 (suggesting a "double clear statement rule"); Posner, supra note 677, at 715 (advocating a clear statement rule because "[i]f the legislators have to go on record as favoring the suppression of competition, they may hesitate to do so.").

760. 435 U.S. at 421 .

761. Id. at 423 .

762. Id. (quoting National League of Cities v. Usery, 426 U.S. 833, 845 (1976), which in turn quoted Coyle v. Oklahoma, 221 U.S. 559, 580 (1911)). 
ted within the Parker exemption, and "the running of a business enterprise is not an integral operation in the area of traditional government functions." 763 Thus, the allegedly anticompetitive activities of the city in the operation of its electric power business were subject to the antitrust laws, under the Burger rationale, if they were not in furtherance of an essential governmental function. One way of determining whether a function is "sovereign" apparently turned on whether the activity was "compel[led]" by the state as "part of a regulatory scheme to supersede competition." "764 Furthermore, relying on the majority component of Cantor, Chief Justice Burger would require a showing that the anticompetitive scheme "was essential to the State's plan"765 i.e., a determination "whether the implied exemption from federal law "was necessary in order to make the regulatory Act work, and even then only to the minimum extent necessary.' ",766

The Burger concurrence focuses exclusively on Tenth Amendment principles of federalism in considering the Parker doctrine, relying on the essential function language of Usery and eschewing consideration of the relationship between states and their political subdivisions. Presumably, the Burger analysis, which goes to the substantive scope of the Parker exemption and relies in part on the majority component of Cantor,$^{767}$ would apply even if the defendant utility were run by a state agency rather than by the City of Lafayette. As the dissent pointed out, the failure to distinguish between states and cities is proper in a Tenth Amendment context. ${ }^{768}$

The disagreements that surfaced in Cantor and City of Lafayette suggest a doctrinal accommodation that encompasses both Tenth and Eleventh Amendment sources of federalism-Parker as a dual exemption. ${ }^{769}$ This may well be the implicit position of Justice Powell, who dissented in Cantor but who joined the plurality in City of Lafayette. ${ }^{770}$ A footnote to the plurality's opinion is instructive in this regard:

Cantor's analysis is not, however, necessarily applicable here. Cantor was concerned with whether anticompetitive activity in which purely private parties engaged could, under the circumstances of that case, be insulated from antitrust enforcement. The situation involved here, on the other hand, presents the issue of under what circumstances a State's subdivisions engaging in anticompetitive activities should be deemed to be acting as agents of the State. ${ }^{771}$

763. 435 U.S. at 424 .

764. Id. at 425 n.6. Accord, New Motor Vehicle Bd. v. Orrin W. Fox Co., 99 S. Ct. 403,412

(1978). See Blumstein \& Calvani, supra note 689 , at 425 n.212.

765. 435 U.S. at 425 n.6.

766. Id. at 426 (quoting Cantor v. Detroit Edison Co., 428 U.S. 579,597 (1976), which in turn quoted Silver v. New York Stock Exch., 373 U.S. 341,357 (1963)).

767. 428 U.S. at $592-98$.

768. 435 U.S. at 430. Justice Stewart cited National League of Cities v. Usery, 426 U.S. 833

855-56 n.20 (1976) as support for his statements.

769. See text accompanying notes 691-92, 715-17, supra.

770. See Blumstein \& Calvani, supra note 689 , at 411 n.133.

771. 435 U.S. at 411 n.40. 
Arguably, Justice Powell views Parker as stemming from both Tenth and Eleventh Amendment sources:

In the context of conferring Parker immunity on private parties [Cantor], he would apply a tenth amendment approach, limited by Goldfarb's requirement that immunity arise only where government compels private anticompetitive conduct. [citation omitted] In the context of determining which governmental units receive Parker immunity, however, perhaps he sees the issue as parallel to the eleventh amendment analysis. In that way, he is able to join the plurality's essentially eleventh amendment, sovereign immunity approach in City of Lafayette. ${ }^{772}$

Adoption of the dual exemption approach would necessitate two inquiries in a case like City of Lafayette, in which a governmental entity or governmental officials were sued. First, the issue addressed by the plurality must be considered-whether the act of the political subdivision (or state agency) "is that of the State as sovereign." 773 This is analogous to the type of inquiry the Court uses to determine the scope of Eleventh Amendment immunity ${ }^{774}$ As articulated by the City of Lafayette plurality, this facet of the analysis would determine whether the "anticompetitive activity engaged in" was "an act of government by the State as sovereign or, by its subdivisions, pursuant to state policy to displace competition with regulation or monopoly public service."775

The second inquiry in the proposed analysis in a City of Lafayette-type of case would focus on the more substantive concerns of Chief Justice Burger's concurrence and the majority component of Cantor. It would examine whether the exercise of governmental authority constituted an attribute of sovereignty and promoted an essential governmental function. Also, there must be a finding of an impairment of traditional governmental sovereign functions. ${ }^{776}$ Presumably, no such impairment exists unless the state can show that no reasonable, less anticompetitive alternative exists by which it can further its goals. ${ }^{777}$ Clearly, the second facet of the dual exemption analysis tracks closely the approach of Chief Justice Burger's concurrence in City of Lafayette ${ }^{778}$ and the majority component of Cantor ${ }^{779}$

In cases where private parties are defendants, the Eleventh Amendment

772. Blumstein \& Calvani, supra note 689 , at $411-12 \mathrm{n} .133$ (citation omitted).

773. 435 U.S. at 410 .

774. E.g., Mt. Healthy City Bd. of Educ. v. Doyle, 429 U.S. 274, 280 (1977); Lincoln County v. Luning, 133 U.S. 529 (1890). See also L. TribE, supra note 347, at $\$ 3-38$.

775. 435 U.S. at 413 . According to the plurality, a political subdivision need not point to a "detailed legislative authorization" in order to assert a Parker defense. Id. at 415 . Although the subordinate political unit may not "as readily" establish a Parker claim as a state government itself may, an "adequate state mandate" will be found "from the authority given a governmental entity to operate in a particular area, that the legislature contemplated the kind of action complained of.' "Id. (quoting City of Lafayette v. Louisiana Power and Light Co., 532 F.2d 431, 434 (5th Cir. 1976)).

776. See Blumstein \& Calvani, supra note 689 , at 419-28.

777. Id. at $426-27$.

778. See id. at 431 n.242.

779. Cantor v. Detroit Edison Co., 428 U.S. 579, $592-98$ (1976). 
component of the dual exemption would be invoked to determine whether the state agency or political subdivision was acting pursuant to expressly articulated state policy to substitute regulation for competition. Only when that threshold is passed is an agency or political subdivision capable of conferring an antitrust exemption. Despite the urging of the Cantor plurality, a majority of the justices is apparently unwilling to restrict Parker's exemption to specified governmental defendants, however. ${ }^{780}$ The substantive facet of the proposed dual exemption would also govern in such private defendant situations. The Court's inquiry would be whether private party exemption was necessary to make the regulatory program work, i.e., essential to avoid an impairment of a traditional sovereign function.

What City of Lafayette and the proposed dual exemption analysis of the state action antitrust exemption will mean can only be determined as more cases are brought. Already, some commentators have suggested that cases involving a zoning ordinance presented opportunities "for the Court to approve an antitrust exemption," 781 since, under the Chief Justice's pivotal concurrence, zoning would be "recognized as a proper local function, and land use regulation is clearly a 'governmental' activity." ${ }^{782}$ Nevertheless, the Court has declined the invitation to review a fifth circuit decision that held that an antitrust suit could be brought against a city and private parties. ${ }^{783}$

In Whitworth $v$. Perkins ${ }^{784}$ the fifth circuit concluded that "[t]he mere presence of [a] zoning ordinance does not necessarily insulate the defendants from antitrust liability where . . the enactment of the ordinance was itself a part of the alleged conspiracy to restrain trade." ${ }^{\prime 85}$ Clearly, where the city participates with a private party in restraining trade, Parker itself ${ }^{\mathbf{7 8 6}}$ suggests the lack of an antitrust exemption. That point was expressly asserted by Justice Blackmun who, though he dissented in City of Lafayette, nevertheless distinguished the situation where a city was "acting in concert with private parties."787 In Whitworth the allegation was that the city, through its zoning ordinance, was protecting a liquor dealer by foreclosing opportunities for competitors to enter the community and sell liquor. There was also an implicit regional dimension in Whitworth because the City of Impact was the only "wet" area-a virtual oasis of over two hundred inhabitants but only thirty-one qualified voters-in an otherwise "dry" county. That fact made the exclusion more decisive from a regional perspective.

780. Blumstein \& Calvani, supra note 689, at 419.

781. The Supreme Court, 1977 Term, supra note 627, at 281 n.28. See also id. at 285.

782. Id. at $281 \mathrm{n} .28$.

783. Whitworth v. Perkins, 559 F.2d 378 (5th Cir. 1977), vacated and remanded sub nom. City of Impact v. Whitworth, 435 U.S. 992 (1978), opinion reinstated and case remanded per curiam sub nom. Whitworth v. Perkins, 576 F.2d 696 (5th Cir. 1978).

784. Id.

785. 559 F.2d at 379 .

786. Parker v. Brown. 317 U.S. $341,351-52$ (1943)

787. 435 L.S. a1 441. 
Another example of alleged anticompetitive collusion between a city and private economic interests was Mason City Center Associates v. City of Mason City. ${ }^{788}$ Plaintiffs sought to develop a regional shopping center on the west side of town. Another group of developers sought to build a regional shopping center in downtown but only "upon the express condition that the City prevent any person or firm from planning or constructing a regional shopping center that would compete with the Downtown Center." ${ }^{899}$ The plaintiffs needed a rezoning to enable them to proceed with their planned development, but requests for rezoning were denied by the Planning and Zoning Commission and by the City Council. Plaintiffs alleged the rezoning denials were carried out "pursuant to and in furtherance of" the anticompetitive agreement. ${ }^{790}$ The district judge, in denying a motion to dismiss for failure to state a claim, emphasized that it was the anticompetitive agreement that was the subject of the antitrust claim, "not the City's decision to deny [plaintiffs'] zoning request, as such and without more."791

The decisions in Whitworth and City of Mason City clearly read a lot like state court decisions on public purpose. ${ }^{792}$ There is a strong undercurrent that suggests the cities are acting in furtherance of private rather than public purposes. That form of analysis falls comfortably within the proposed analytical framework; decisions furthering private interests cannot be necessary for promoting essential governmental functions in the Usery sense, and failure to confer an antitrust exemption on private parties in such situations can hardly impair the integrity of government in performing sovereign functions. Consequently, the threshold Eleventh Amendment type issue-whether the city's action qualifies as action of the state-is not even reached because, even assuming that the city stands in the shoes of the state procedurally, its action does not warrant Parker protection.

The difficult questions lie ahead in the exclusionary zoning and growth management contexts. Clearly, under the proposed dual exemption analysis there is room for a court to conclude that parochial land use restrictions are no more than governmentally legitimized products of the homeowner cartels Professor Ellickson decries. ${ }^{793}$ In such situations, a court could easily conclude that such exclusionary purposes or effects were not "contemplated"794 by the state when it delegated land use control to local governments. ${ }^{795}$ Similarly, a court could conclude that a parochial local decision-especially if imple-

788. 468 F. Supp. 737 (N.D. Iowa 1979).

789. Id. at 740 .

790. Id.

791. Id. at 741 n.4.

792. E.g., Price v. Philadelphia Parking Auth., 422 Pa. 317, 221 A.2d 138 (1966). See 6 E.

MCQuiLlin, supra note 2, at $\$ 24.09$.

793. See Ellickson, supra note 9, at 392-402, 404-10, 425-35.

794. 435 U.S. at 415.

795. For an example see id. at 414 n.44. 
mented by a referendum-that was at odds with regional welfare was not sufficiently reflective of broad state policy to qualify for Parker immunity under City of Lafayette. The clear statement rule of City of Lafayette could easily be held to require a more direct statement of state policy than a generalized decision to delegate authority to local units of government to make land use decisions. ${ }^{796}$

From the perspective of the substantive component of the proposed dual exemption analysis, restrictive suburban land use legislation could be viewed as either not promoting an essential governmental function or, at least, as not a necessary part of a rational planning program. Especially where the homeowners implement a restrictive development plan through direct democracy, the element of state-imposed compulsion vanishes, suggesting that the policy is more discretionary and less basic to government's ability to function effectively in a federal system.

While the Court can allow for greater effect of the antitrust laws in curtailing some suburban anticompetitive activity, the question of judicial role remains. ${ }^{797}$ An active court threatens a "return to the regime of substantive due process and [a] repudiat[ion of] the values of federalism protected by Parker ...."798 A restrained court allows anticompetitive abuses to benefit suburban homeowners at the expense of others. The lack of a federal constitutional remedy suggests a statutory alternative, especially since such decisions do not have the permanency of constitutional adjudications. ${ }^{799}$ At a minimum, a community should not be permitted to justify a policy on the ground that it promotes the local welfare at the expense of unrepresented nonresidents. ${ }^{\mathbf{8 0 0}}$ The City of Lafayette decision, when read in conjunction with Cantor, allows the Court to go further; whether it will allow the statutory law to evolve in an antitrust context as it has in the fair housing area ${ }^{801}$ remains to be seen, but it is perhaps noteworthy that the Court did not jump at the opportunity presented, in the aftermath of City of Lafayette, to limit its application. ${ }^{\mathbf{8 0 2}}$

796. Siee 1 P. Areeda \& D. Turner, supra note 677, at $9214 \mathrm{e}$; The Supreme Court, 1977 Term, supra note 627 , at 282-83. This could also be a means for giving effect to the regional dictum in Euclid in a non-constitutional setting. See text accompanying note 11, supra. See also Section V.B., supra.

797. See 435 U.S. at 416 n.46; id. at $434-41$ (Stewart, J., dissenting); 428 U.S. at 629-640 (Stewart, J., dissenting). But see Blumstein \& Calvani, supra note 689, at 428-31; Posner, supra note 677; Slater, supra note 677.

798. The Supreme Court, 1977 Term, supra note 627, at 286.

799. Blumstein \& Calvani, supra note 689, at 428-31. See 435 U.S. at 416 n.46.

800. The Supreme Court, 1977 Term, supra note 627, at 286. See also Ellickson, supra note 9, at 469-75; Note, supra note 400; supra note 796.

801. See Section VI.A., supra.

802. See Whitworth v. Perkins, 559 F.2d 378 (5th Cir. 1977), vacated and remanded sub nom. City of Impact v. Whitworth, 435 U.S. 992 (1978), opinion reinstated and case remanded per curiam sub nom. Whitworth v. Perkins, 576 F.2d 696 (5th Cir. 1978); The Supreme Court, 1977 Term, supra note 627 , at 281 n.28. 